\title{
REVISITING MARINE BIOPROSPECTING OF TROPICAL INDONESIAN MACROALGAE FROM WEST TIMOR
}

Turupadang, Welem Linggi
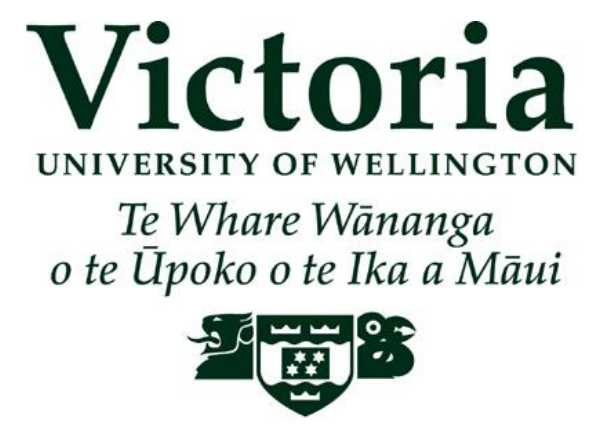

$w w w, v u w, a c, n z$

A thesis

submitted to Victoria University of Wellington in fulfilment of the requirements for the degree of Master of Science in Chemistry. 


\section{Abstract}

Marine algae are an important and historically rich source of new marine-based natural products. This thesis describes the screening of 40 Indonesian macroalgal samples using liquid chromatography-mass spectrometry (LC-MS) based molecular networking, and the subsequent nuclear magnetic resonance (NMR)-guided isolation and structural elucidation of a 6-deoxy-6-aminoglycoglyrecolipid (60). Molecular networking was performed using LC-MS/MS data through the online Global Natural Product Social Molecular Networking (GNPS) platform directly from crude extracts. NMR spectroscopy-guided screening was also employed targeting unique peaks detected by ${ }^{1} \mathrm{H}$ NMR to validate any hits from GNPS. Out of 40 macroalgae specimens collected from West Timor waters, six samples were prioritised by the molecular networking screening. Proton NMR revealed three specimens with significantly interesting peaks but only one specimen, Laurencia snackeyi was purified further, which yielded compound 60 .
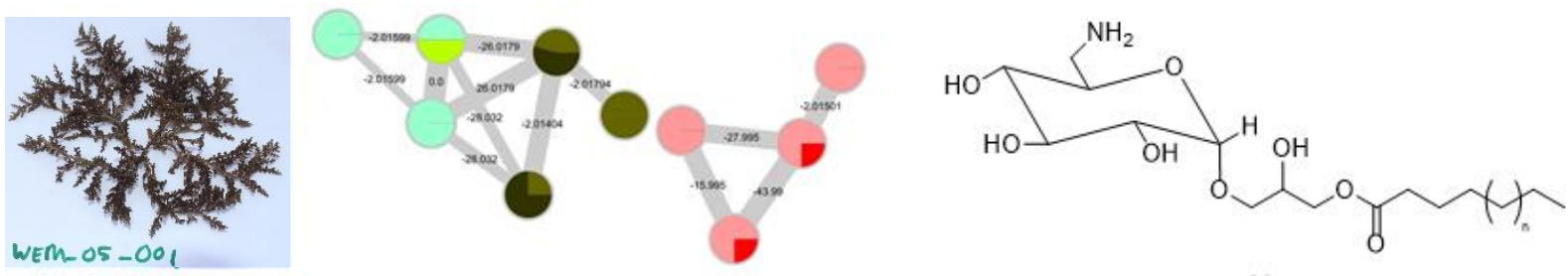


\section{Acknowledgements}

I am humbly grateful to Abba Father throughout my study at Victoria University of Wellington, how much knowledge and experience that has been passed on by academics (especially during my formative year doing my graduate Diploma), fellow students and postgrads, as well as technicians over the past two-and-a-half year in the School of Chemical and Physical Sciences (SCPS). Thank you very much.

My fabulous supervisor Dr Rob Keyzers, thank you for your guidance, patience and wisdom; also, for being a guru and mentor during my study; I benefit not only academically and through laboratory skills but also how you have inspired me to be a good teacher and serve students from different backgrounds. Also, even before I came to New Zealand, how you and Shona De Sain encouraged me to further my study here at SCPS and it was definitely the best decision I have made in these past three years. Associate Professor Joe Zuccarello who helped with importing the algae to New Zealand and taught me how to identify seaweed taxonomic through DNA. To the Natural Product Groups over the years, thanks for making the laboratory work go smoothly and for always providing a good discussion for NMR based problems. Particularly thank you to Sarah Andreassend for your help on the molecular network and giving input to my draft; Dr Helen Woolner and Joe Bracegirdle both for your NMR knowledge, also to Brett, Lara, Leo and Esther who I love to hang out with between classes. Ian Voster, Teresa Gen, Patricia Stein, thank you guys for making my study a lot easier.

Also, thanks to Sarah Clark who helped with the early drafts and the people in the Rongopai flat: Nathan, Lizzie, Lauren, Hudson, David, Andrew, Ben who always supplied good kai, korero and karakia during my stay there.

My parents and family at home, the love of my life: Joice Djiloy, I love you heaps guys, thank you for all your support and prayers. Lastly to New Zealand Scholarship and Universitas Nusa Cendana, Kupang, Indonesia that provided support for my entire study. 


\section{Table of Contents}

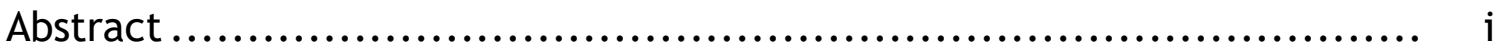

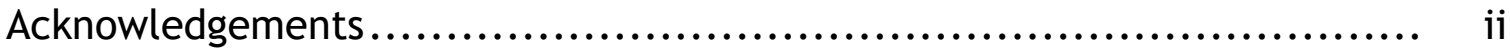

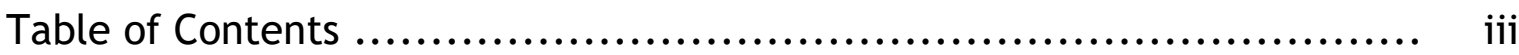

List of Figures ........................................................

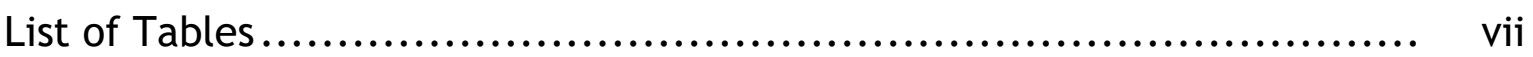

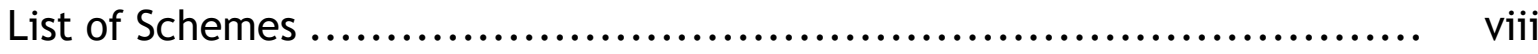

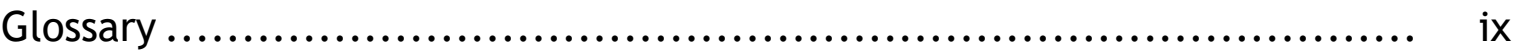

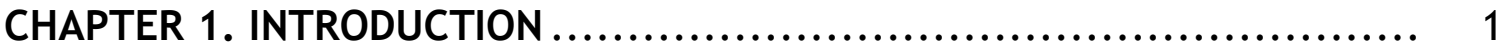

1.1. History of traditional medicines and natural product discovery ....... 1

1.2. Marine natural products........................................... 5

1.3. Indonesia biodiversity ......................................... 6

1.4. Indonesian marine natural products................................ 7

1.5. Macroalgae natural products .................................. 10

1.6. Macroalgae natural product in Indonesia: status and potential........ 13

1.7. Proposed research.............................................. 14

CHAPTER 2. MOLECULAR NETWORKING TO SCREEN MACROALGAL SECONDARY METABOLITES ...................................................... 15

2.1. Screening and dereplication of secondary metabolites ............... 15

2.2. Isolating secondary metabolites ................................. 16

2.3. Liquid chromatography-mass spectrometry ........................ 19

2.4. Algal screening through Global Natural Product Social Molecular

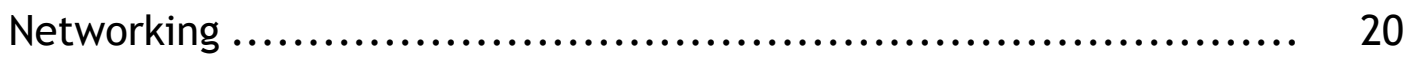

2.5. Sampling of Indonesian macroalgal from West Timor ................. 22

2.6. LC-MS Screening results of West Timor macroalgal .................... 24

2.7. NMR-guided screening ........................................ 31

CHAPTER 3. WEST TIMOR MACROALGAE MARINE NATURAL PRODUCTS:

Laurencia snackeyi....................................................... $\quad 32$

3.1. Introduction ................................................. 32

3.2. Chemical investigations of Laurencia species ....................... 33

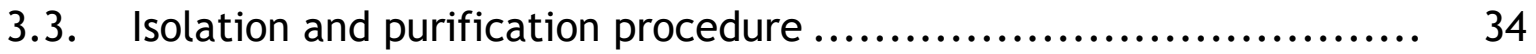

3.4. Structure elucidation of aminoglyceroglycolipid - WEM3_24C ......... 36 
3.5. Deoxyaminoglycoglycerolipids...................................... 40

CHAPTER 4. CONCLUDING REMARKS ................................. 42

CHAPTER 5. EXPERIMENTAL ......................................... 44

5.1. Sampling location .............................................. 44

5.2. Deoxyribonucleic acid barcoding ................................ $\quad 45$

5.3. Sample extraction............................................. 45

5.4. Global natural product social molecular networking ................. 45

5.5. Isolation of compound from Laurencia snackeyi ..................... 46

BIBLIOGRAPHY................................................... 47

APPENDIX A: MARINE NATURAL PRODUCTS RESEARCH IN INDONESIA .......... 61

APPENDIX B: MACROALGAE COLLECTED FROM WEST TIMOR WATERS,

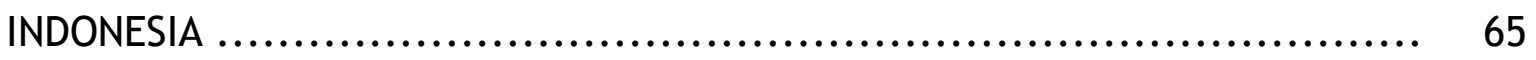

APPENDIX C: MACROALGAE EXTRACTS AFTER FREZE-DRY AND READY TO BE

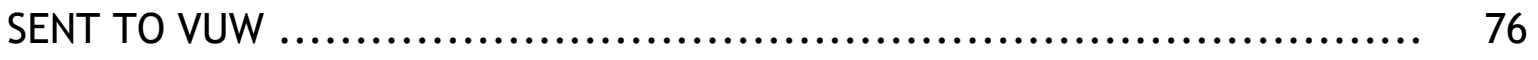

APPENDIX D: 6-deoxy-6-aminoglycoglyrecolipid SPECTRA ................... 77 


\section{List of Figures}

1.1. Chemical structure of reserpine (1), morphine (2), salicin (3), quinine (4), and aspirin (5)

1.2. Chemical structure of penicillin $G(6)$, artemisinin (7), quinoline (8), and paclitaxel (9).

1.3. Chemical structure of sorafenib (10), spongothymidine (11), spongouridine (12), Ara-C (13), Ara-A (14), and ziconotide (15)...

1.4. Chemical structure of trabectedin (16) and eribulin mesylate (17) .... 5

1.5. Map showing the twelve Indonesia marine ecoregions as defined in the Marine Ecoregions of the World classification scheme

1.6. Chemical structure of $(+)$-africanol (18), $\Delta 9(12)$-Capnellene sesquiterpenes (19), (+)- $\Delta 9(12)$-capnellene-3B, $8 B, 10 a, 14 B$-tetraol (20), and aromadendrene (21)

1.7. Frequency of marine natural products research from new and novel compound from Indonesia based on provinces Figure 1.8. Chemical structure of boneratamides-A (22), boneratamides-B (23), microspinosamide (24)

1.8. Chemical structure of boneratamides-A (22), boneratamides-B (23), microspinosamide (24)

1.9. Chemical structure of manadomanzamines $A(25)$, manadomanzamines B (26), naamidines H (27), naamidines I (28), herbaric acid (29), Sumiki's acid (30), acetyl Sumiki's acid (31), xestodecalactones $A, B$, and $C(32-34)$

1.10. Chemical structure of Chemical structure of polyhalogenated monoterpene (35), bisnormonoterpenoid (36), thyrsiferol (37), flexilin (38), caulerpenyne (39), rhipocephalin (40), (S)-12hydroxygeranylgeraniol (41), and diphlorethohydroxycarmalol (42) ....

1.11. Chemical structure of vidalenolone (42) and gracilarioside (44)

2.1. Schematic showing the mass distribution in a typical marine macroalgae extracts

2.2. Cyclic loading process in the HP-20 column

2.3. Component of an LC-MS system.

2.4. A scheme shows how molecular networks are created from LC-MS data

2.5. Sampling locations of macroalgae from West Timor waters, Indonesia.

2.6. Phylogram displaying clustering of the included species Laurencia snackeyi

2.7. (a) GNPS network of macrolagae based upon sampling locations in positive ion mode

2.7. (b) GNPS network of macrolagae based upon sampling locations in negative ion mode 
2.8. (a) GNPS network of macrolagae based upon phylum in positive ion mode

2.8. (b) GNPS network of macrolagae based upon phylum in negative ion mode

2.9. GNPS network of macrolagae based on specimens

2.10. ${ }^{1} \mathrm{H}$ NMR spectra from $75 \%$ semi-purified fractions of six prioritized samples of macroalgae.

3.1. Specimen Laurencia snackeyi collected from Tablolong Beach.......... 32

3.2. Previous secondary metabolites extracted from Laurencia snackeyi .... 34

3.3. COSY correlations establishing a carbon chain consistent with a sugar moiety

3.4. COSY and $\mathrm{HMBC}$ correlations establishing a connection between a sugar moiety, a glycerol, and lipid unit

3.5. Coupling constants determination of the relative amino-sugar moiety . 38

3.6. ROESY correlations establishing connection between the sugar moiety and glycerol functionality ................................. $\quad 40$

3.7. Metabolites from deoxyaminoglycoglycerolipids marine algae .......... 41 


\section{List of Tables}

2.1. Number of macroalgal collected on each site based on phylum ....... 22

3.1. Taxonomic classification of Laurencia snackeyi........................ 33

3.2. Tabulated NMR of WEM3_24C for 6-deoxy-6-aminoglycoglyrecolipid

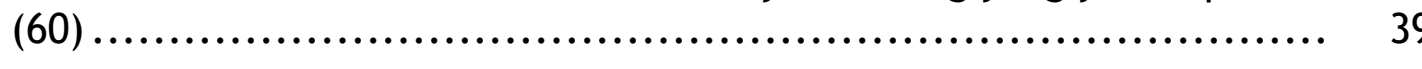




\section{List of Schemes}

3.1. The procedure leading to the isolation of WEM3_24C from WEM_05-

001 


\section{Glossary}

$\delta$

${ }^{13} \mathrm{C}$ NMR

${ }^{1} \mathrm{H}$ NMR

APCI

API

$\mathrm{C}_{18}$

$\mathrm{CD}_{3} \mathrm{OD}$

COSY

Cox1

CTAB

DCM

d

dd

ddd

DIOL

DNA

ESI

EtOAc

EtOH

GNPS

$\mathrm{H}_{2} \mathrm{O}$

$\mathrm{H}_{2} \mathrm{SO}_{4}$

HMBC

HP20

HP20

HPLC

HPLC

HSQC

J

LC
Chemical shift (ppm)

Carbon-13 nuclear magnetic resonance

1H NMR Proton nuclear magnetic resonance

Atmospheric Pressure Chemical Ionization

Atmospheric-Pressure lonization

Octadecyl derivatised silica

Deuterated Methanol

Correlation spectroscopy

Mitochondrial marker cytochrome oxidase subunit I

Cetyl trimethylammonium bromide

Dichloromethane

Doublet

Doublet of doublets

Doublet of doublet of doublets

2,3-dihydroxypropoxy-propyl-derivatised silica

Deoxyribonucleic acid

Electrospray lonization

Ethyl acetate

Ethyl alcohol

Global Natural Product Social Molecular Networking

Water

Sulfuric acid

Heteronuclear multiple-bond correlation spectroscopy

Copolymer

PSDVB stationary support

High-Performance Liquid Chromatography

High-performance liquid chromatography

Heteronuclear single-quantum correlation spectroscopy

Scalar coupling constant $(\mathrm{Hz})$

Liquid chromatography 


\begin{tabular}{|c|c|}
\hline LC-MS & Liquid chromatography-mass spectrometry \\
\hline LC-MS/MS & $\begin{array}{l}\text { Liquid chromatography-mass spectrometry/mass } \\
\text { spectrometry }\end{array}$ \\
\hline m & Multiplet \\
\hline $\mathrm{m} / \mathrm{z}$ & Mass-to-Charge Ratio \\
\hline $\mathrm{Me}_{2} \mathrm{CO}$ & Acetone \\
\hline $\mathrm{MeOH}$ & Methanol \\
\hline MS & Mass spectrometry \\
\hline NMR & Nuclear magnetic resonance \\
\hline PCR & Polymerase chain reaction \\
\hline ppm & Parts per million \\
\hline PSDVB & Poly-styrene divinylbenzene \\
\hline QTOF & Quadrupole Time-of-Flight \\
\hline ROESY & $\begin{array}{l}\text { Rotating-frame nuclear Overhauser effect } \\
\text { spectroscopy }\end{array}$ \\
\hline $\mathbf{s}$ & Singlet \\
\hline SCPS & School of Chemical and Physical Sciences \\
\hline SCUBA & Self-contained underwater breathing apparatus \\
\hline t & Triplet \\
\hline TLC & Thin-layer chromatography \\
\hline TOF & Time-of-Flight \\
\hline VUW & Victoria University of Wellington \\
\hline
\end{tabular}




\section{CHAPTER 1. INTRODUCTION}

\subsection{History of traditional medicines and natural product discovery}

Nature has been a source of traditional remedies, useful for cures and treatment for human civilization throughout history. The ancient Egyptians have recorded the application of traditional medicines as early as $2900 \mathrm{BC}$, in the form of the Ebers Papyrus, which provides numerous types of remedies based on plants. ${ }^{1}$ Another old record dated back to $2600 \mathrm{BC}$, when a clay-tablet cuneiform from Mesopotamia documented the application of cypress and myrrh as pharmaceutical agents. ${ }^{2}$ Two Greek physicians, Hippocrates of Cos (circa 460-377 BC) and Galen (129-200 AD), developed about 400 natural agents and 540 herbal extracts respectively. ${ }^{3}$ Hippocrates, for example, prescribed an extract of Atropa belladonna, commonly known as deadly nightshade, as an anesthetic and also advised the use of Ornithogalum caudatum (squill) juice, which might help diuresis. $^{3}$

Like its European counterpart, natural remedies also flourished in China and India. Wu Shi Er Bing Fang, an ancient medical text, recorded the use of about 247 plantderived agents as well as 150 notes of drug formulae compiled around $350 \mathrm{BC}$ by the Chinese. Following that, the monograph Shen Nong Ben Cao Jing (Shen Nong Materia Medica) produced during the Eastern Han dynasty (25-220 AD), documented 253 plant-based and 67 of animal derived medicines. ${ }^{2-3}$ These include anti-asthmatics from Ephedra sinica (ephedra herb), Coptis root (Coptis chinensis) as a remedy for diarrhea, and an antihelminthic from chinaberry seed (Melia azedarach).

Like the Chinese, the Indian Ayurveda system, dating back to $900 \mathrm{BC}$, also had a document called Charaka Samhita, which prescribed 341 plant-based remedies. ${ }^{4}$ Another record worth mentioning is the Sushruta Samhita (circa 600 BC), which provides around 453 complementary natural medicines alongside primarily surgical procedures. ${ }^{5}$ A significant achievement from the Ayurvedic legacy to modern medicine is reserpine (1, Figure 1.1), a tranquilizer isolated from the sarpagandha plant (Rauwolfia serpentina), which is a therapeutic agent for hypertension, insomnia, and insanity. ${ }^{6}$ 
The activity of traditional remedies comes from secondary metabolites produced by an organism. These active secondary metabolites produced, by living organisms, are referred as natural products. Natural products are compounds that are not necessarily needed to maintain functionality, differentiated from primary metabolites (such as glucose or DNA) which are essential compounds required for metabolism and for organisms to survive. Secondary metabolites are rare and offer novel structures and functionalities compared to primary metabolites.

Throughout history, traditional remedies have provided a solid ground for discovering modern medicines. The era of modern drugs began in the nineteenth century when a German pharmacist, Friedrich Sertürner, successfully isolated several alkaloids including morphine (2, Figure 1.1) from opium poppy Papaver somniferum L. ${ }^{1}$ Morphine was then commercialized by Merck in 1826 as the first plant-based natural products. ${ }^{3}$ Following this progress, more compounds were found including an analgesic, salicin (3, Figure 1.1) from willow bark and an antimalarial drug, quinine (4, Figure 1.1) from cinchona bark. ${ }^{6}$ Salicin was later developed by Bayer in 1900 as a pain reliever, which have commercially known as aspirin (5, Figure 1.1). ${ }^{7}$

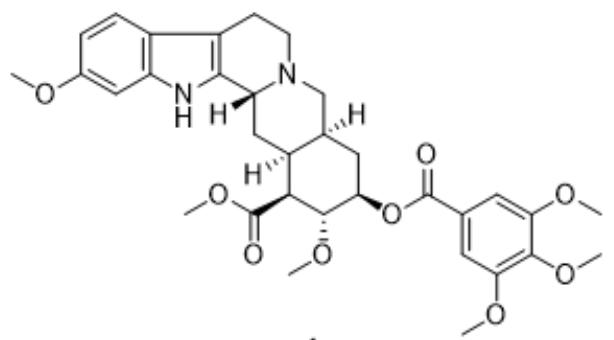

1

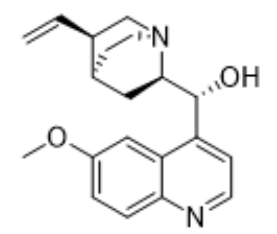

4

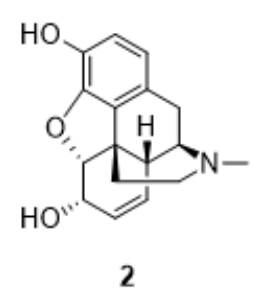

2

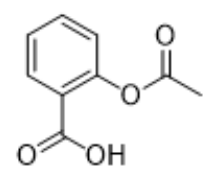

5

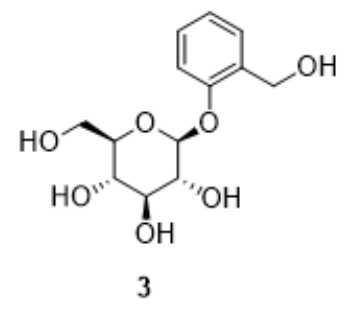

3

Figure 1.1. Chemical structure of reserpine (1), morphine (2), salicin (3), quinine (4), and aspirin (5)

At the beginning of the twentieth century, natural products continued to make a tremendous contribution to human civilization and provided tools for scientists to 
overcome many modern diseases. In 1929, Alexander Fleming continued the positive era of bioactive natural products by discovering the antibacterial properties of penicillin G (6, Figure 1.2) from the mold Penicillium notatum, which at that time helped physicians to battle infectious diseases. ${ }^{3}$ Other key drugs in the modern era are artemisinin (7, Figure 1.2) and quinoline (8, Figure 1.2), which are both used today as first-line drugs to combat malaria. ${ }^{8}$ Artemisinin was discovered by Tu Youyou, a Chinese scientist, in the late 1960s from the sweet wormwood plant (Artemesia annua). Later in the late 1970s, Wani et al., discovered paclitaxel (Taxol®; 9, Figure 1.2) from the plant Taxus brevifolia. ${ }^{9}$ Taxol underwent lengthy development before it was clinically approved as one of the treatments against ovarian cancer and breast cancer in 1992 and 1994, respectively. ${ }^{2}$

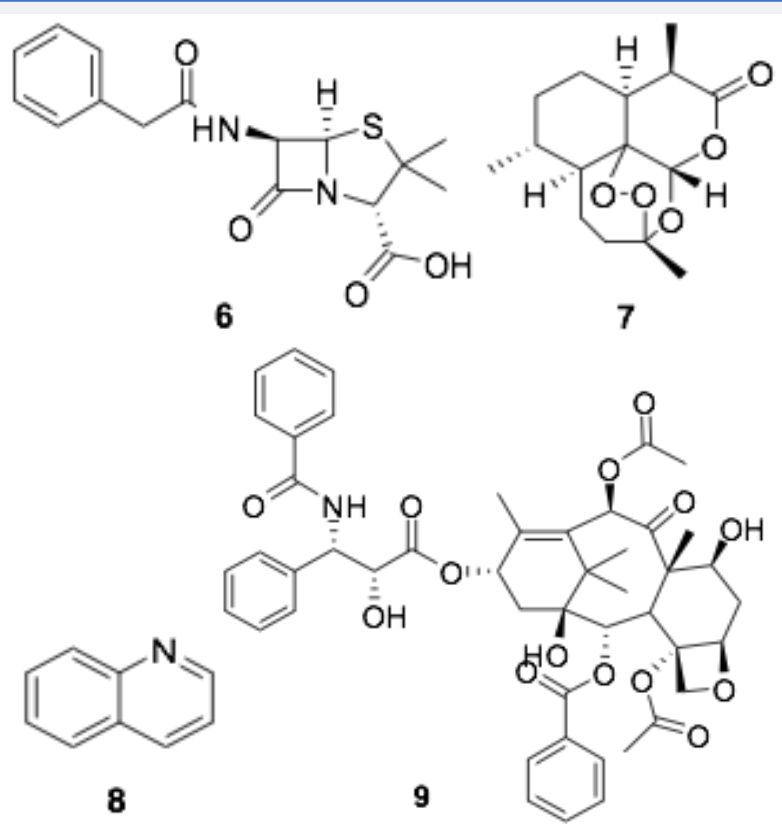

Figure 1.2. Chemical structure of penicillin $G(6)$, artemisinin (7), quinoline (8), and paclitaxel (9)

However, the slow output of drug research and development (R\&D) programs of natural products in many pharmaceutical companies in the late 1980s resulted in the closure of many departments in the industry. ${ }^{10}$ After the 1980 s, the number of newly discovered molecules plunged from 60 new chemical entities (NCEs) on a yearly basis in the 1980s to $18-34$ per year de novo discoveries in the decade 2001-2010. The decline happened due to the development of high-throughput screening (HTS), which marginalized the role of natural products in drug discovery by the majority of pharmaceutical industries. 2, 10-11 HTS technology, based on 
combinatorial chemistry, continued to be the backbone method of optimizing structures of many compounds. ${ }^{12}$ Practically, natural products chemistry was abandoned in this particular period. ${ }^{1,13}$

In a later development, however, HTS failed to address productivity in drug discovery where fewer compounds made it beyond clinical trials. In fact, there was only one combinatorial chemistry-derived NCE approved by the U.S Food and Drug Administration (FDA), ${ }^{1,10}$ the multi-kinase inhibitor, sorafenib (Nexavar ${ }^{\circledR} ; 10$, Figure 1.3) from Bayer which is a treatment for renal carcinoma (approved by the FDA in 2005). Natural products once again obtained momentum in the drug design and discovery by its "nature's privileged structure," a structure that can be obtained only from actively perform bioprospecting from the nature. ${ }^{11}$ Consequently, there have been recent increases in natural products-based drug discovery.

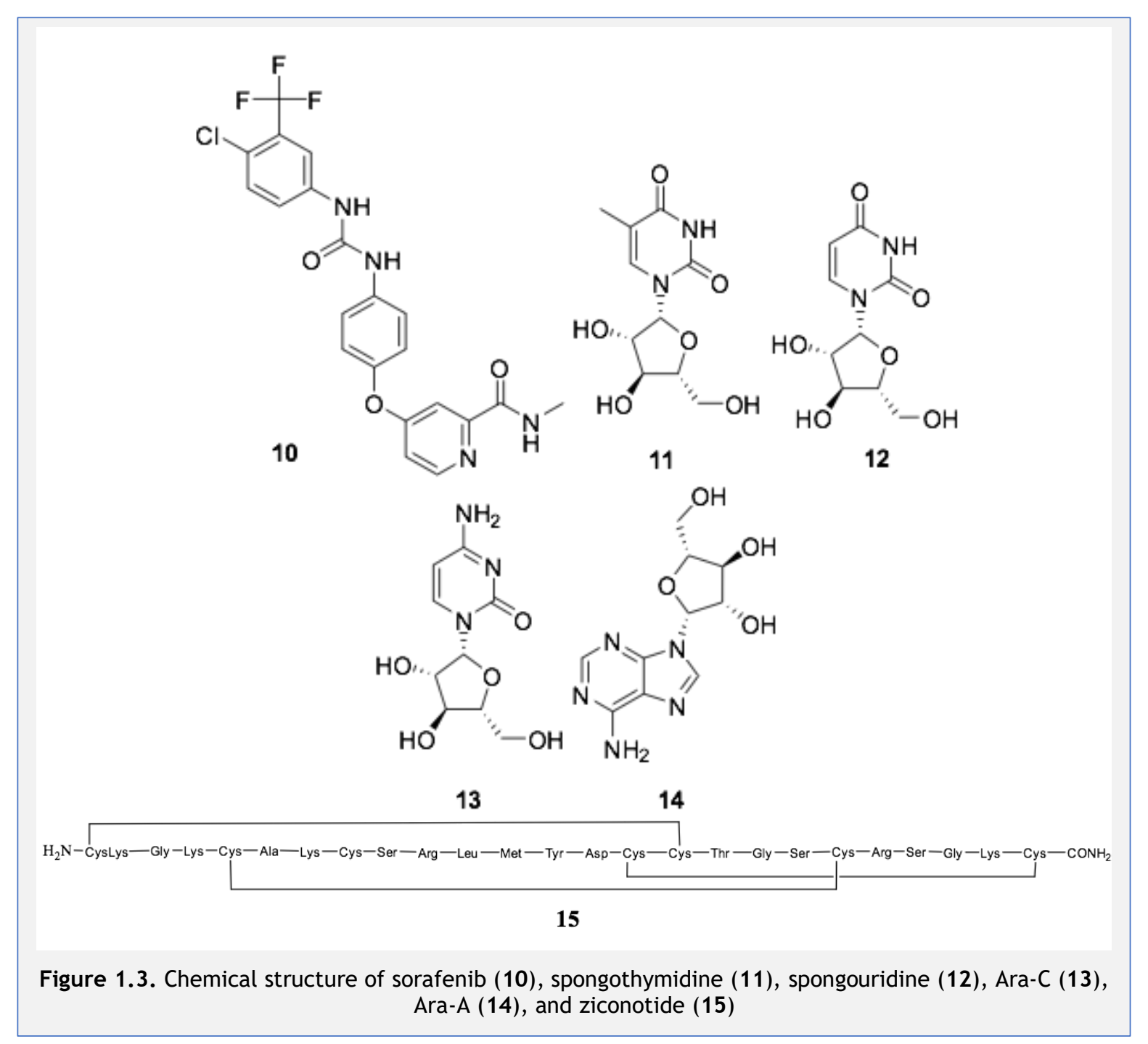




\subsection{Marine natural products}

Natural products as lead compounds have mainly come from terrestrial plants and microbes as they are widely accessible to collect. ${ }^{14}$ An effort to explore the medicinal potential of marine natural products (MNPs) was first detailed at a conference in Rhode Island, USA, in the 1970s. Improved sampling methods, e.g., SCUBA apparatus, has contributed significantly to the progress of discovery new MNPs, not to mention the development of spectroscopy technology and screening protocols. ${ }^{15}$ As a result, the number of new marine natural products has increased from 332 in $1984^{16}$ to 1340 in $2016 .{ }^{17} \mathrm{New}$ compounds have been isolated from marine organisms in subtidal and intertidal zones including micro and macroalgae, littoral plants, various invertebrates (poriferans, anthozoan, bryozoans, mollusks, tunicates, echinoderms, and bacteria). ${ }^{17}$

The first MNPs were reported in 1951 when two nucleosides, spongothymidine (11, Figure 1.3) and spongouridine (12, Figure 1.3), were extracted from the Caribbean sponge Tethya crypta. ${ }^{18-19}$ These compounds led to three drugs, which have antiviral (Ara-A, commonly known as Vidarabine), anticancer (Ara-C also known as Cytosar-U), and anti-HIV activities (azido thymidine-AZT). ${ }^{20-21}$ In fact, both Ara-C or Cytarabine (13, Figure 1.3) and Ara-A (14, Figure 1.3) were the first MNPderived drugs approved by the FDA in 1969 and 1976, respectively. ${ }^{22}$ However, ziconotide (15, Figure 1.3), a $\omega$-conotoxin MVIIA (25 amino acid peptide chain) was the first FDA approved drug extracted and isolated directly from its source, the Indo-Pacific marine snail Conus magus. ${ }^{23-24}$

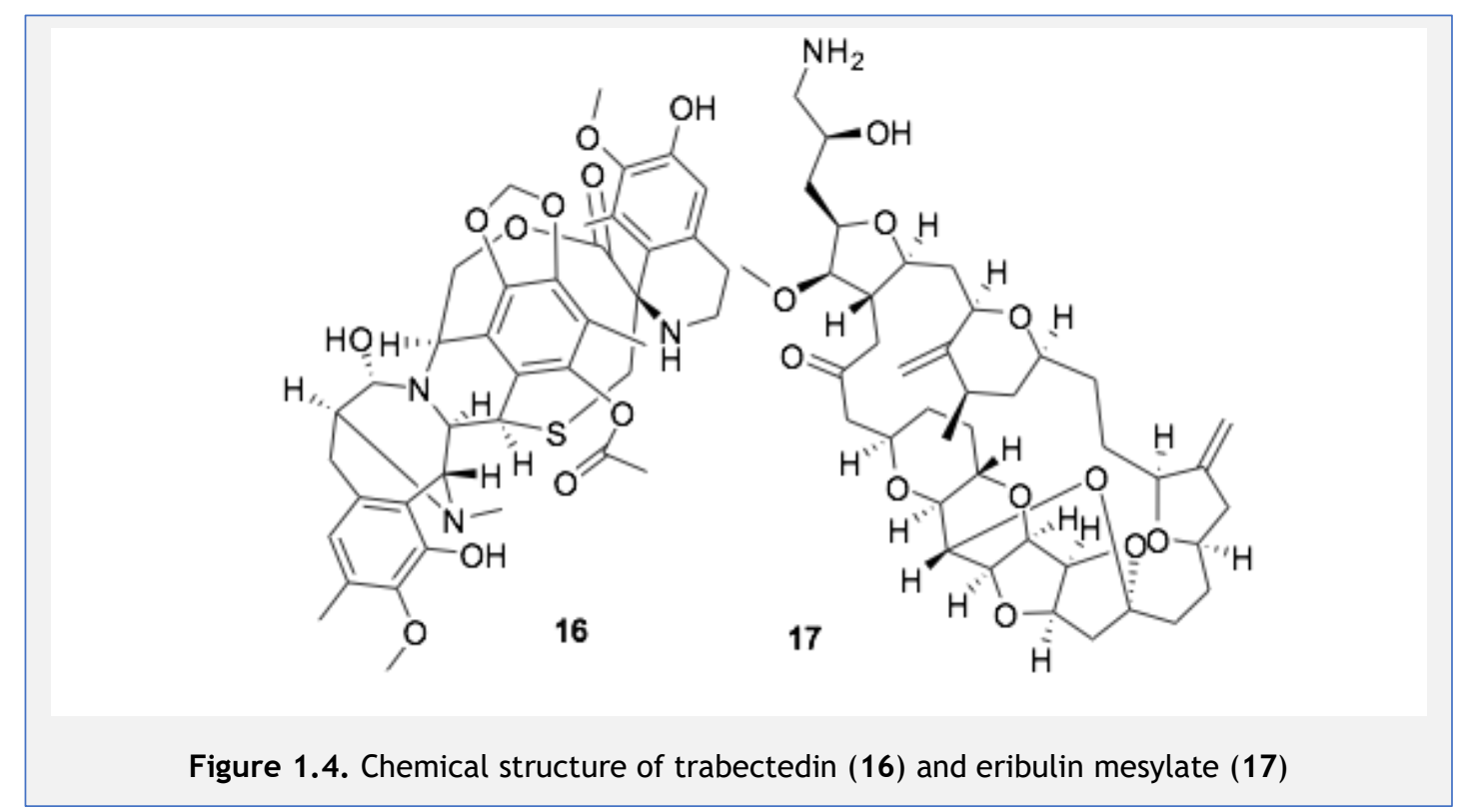


Currently, there are six FDA approved MNPs drugs including the aforementioned drugs, trabectedin (Yondelis) (16, Figure 1.4) and eribulin mesylate (17, Figure 1.4). ${ }^{10,20}$ Trabectedin, a tris(tetrahydroisoquinoline) alkaloid, was isolated from Ecteinascidia turbinata and is used for the treatment of non-operable soft tissue sarcomas. ${ }^{24}$ Eribulin mesylate is a synthetic analogue of halichondrin B, extracted from the Japanese sponge Halichondria okadai, and is an FDA-approved treatment for metastatic breast cancer. ${ }^{25}$

Despite only a small number of MNPs drugs being approved, many of them are still in clinical trials, ${ }^{26}$ which still provides huge potential for development. At present, there are five compounds in phase III clinical trials, which come from fungi, pufferfish, tunicates, and mollusks. Also, there are ten and six compounds in phase II and I clinical trials respectively, which most of them are coming from mollusks. Most of these compound target a variety of cancers (an updated list of current marine-derived compounds on the drug pipeline is available on the following website: http://marinepharmacology.midwestern.edu/clinical_pipeline.html).

\subsection{Indonesia biodiversity}

Indonesia has been privileged with the world's third most mega-biodiversity, according to the United Nations Environment Programme-UNEP. ${ }^{26}$ It has 47 ecosystem types, ranging from ice fields and alpine meadows to coral-reefs, with approximately $17 \%$ of the total number of species in the world found in Indonesia. ${ }^{27}$

Regarding marine biodiversity, Indonesia lies at the heart of the Coral Triangle region (part of Coral Triangle Initiative ${ }^{\dagger}$ ) which consists of 43,682 square kilometers of coral reef spanning from the Philippines in the north to the Solomon Islands in the south. Nearly 50 percent $(19,868 \mathrm{sqkm})$ of the area is located in Indonesia, providing habitats for 500 species of coral (18 percent of the world's coral reefs) and 5,000 species of fish and mollusca on top of numerous marine plant species. ${ }^{28}$ For this reason, it has attracted many researchers to examine the full potential of marine biodiversity in Indonesia.

${ }^{+}$Coral Triangle Initiatives consist of six nations: Indonesia, Malaysia, the Philippines, Papua New Guinea, the Solomon Islands and Timor Leste 


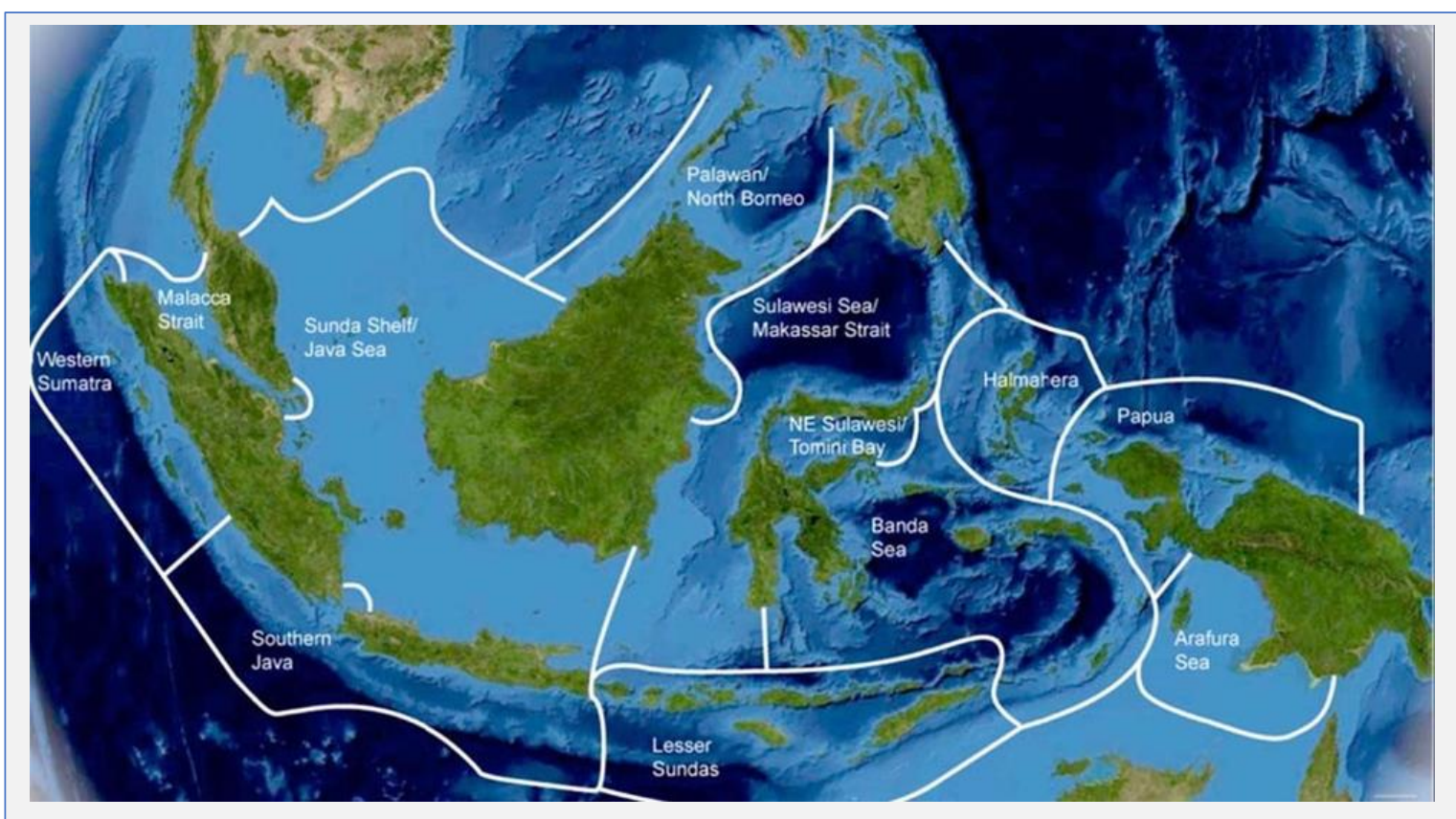

Figure 1.5. Map showing the twelve Indonesia marine ecoregions as defined in the Marine Ecoregions of the World classification scheme $28-30$

\subsection{Indonesian marine natural products}

Marine natural products research in Indonesia has captured research attention mainly in the period between 2002 and 2003, as well as 2012-2013. However, the first reported paper of MNPs in Indonesia was in 1974 when tricyclic (+)-africanol (18, Figure 1.6) was isolated from the soft coral Lemnalia africana (Leti Island, Maluku). ${ }^{31}$

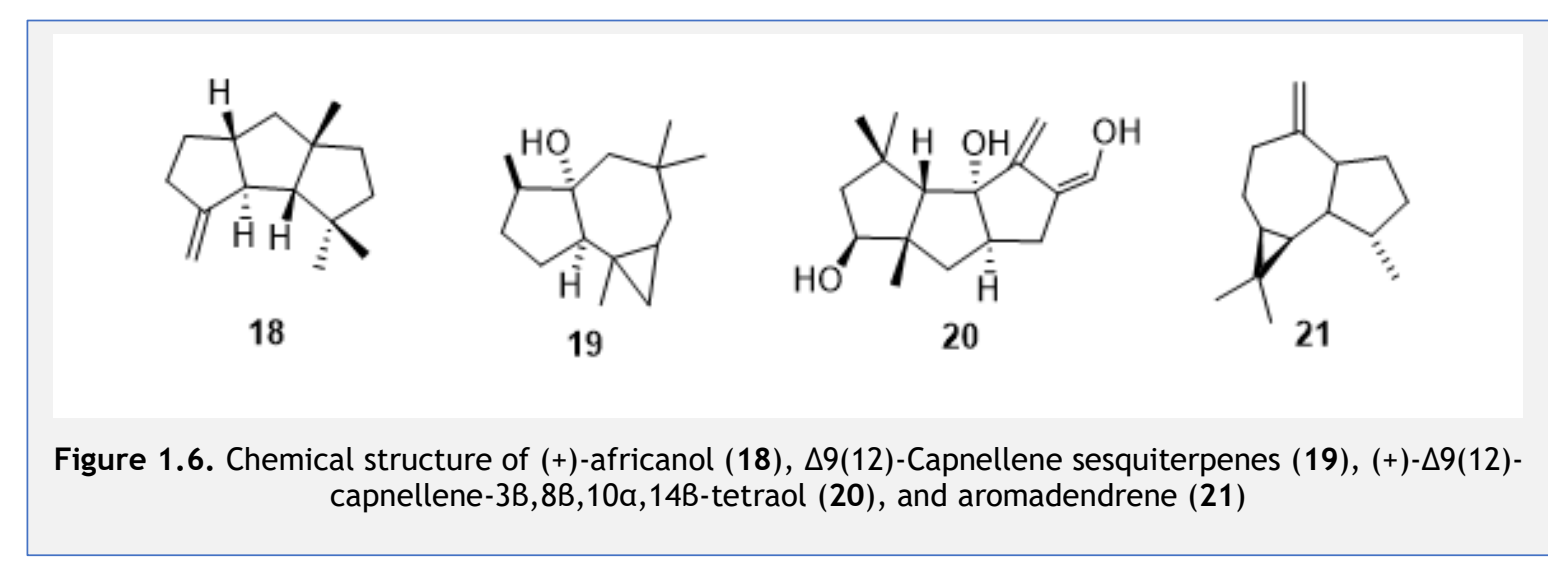

Later that decade, a few researchers had also reported their findings from another soft coral genus Capnella as sources of $\Delta 9$ (12)-capnellene sesquiterpenes ${ }^{32}$ (19, Figure 1.6), while tetraol (+)- $\Delta 9(12)$-capnellene-3B,8B,10a,14B-tetraol (20, Figure 1.6) was found from a specimen collected at the same location in 1977.33 
Another group reported that they successfully isolated aromadendrene (21, Figure 1.6) from the soft coral Sinularia mayi (from Nias Island) in $1978 .{ }^{34}$

Among marine species, sponges have been the richest sources of bioactive compounds from Indonesia, comprising almost $60 \%$ of total research covered in this introduction chapter, followed by fungi, tunicates, and other invertebrates (Figure 1.7; see Appendix A). Most of the research has been done in Sulawesi Island especially North and South Sulawesi Provinces which accounted for 22 and 16 published papers, respectively.

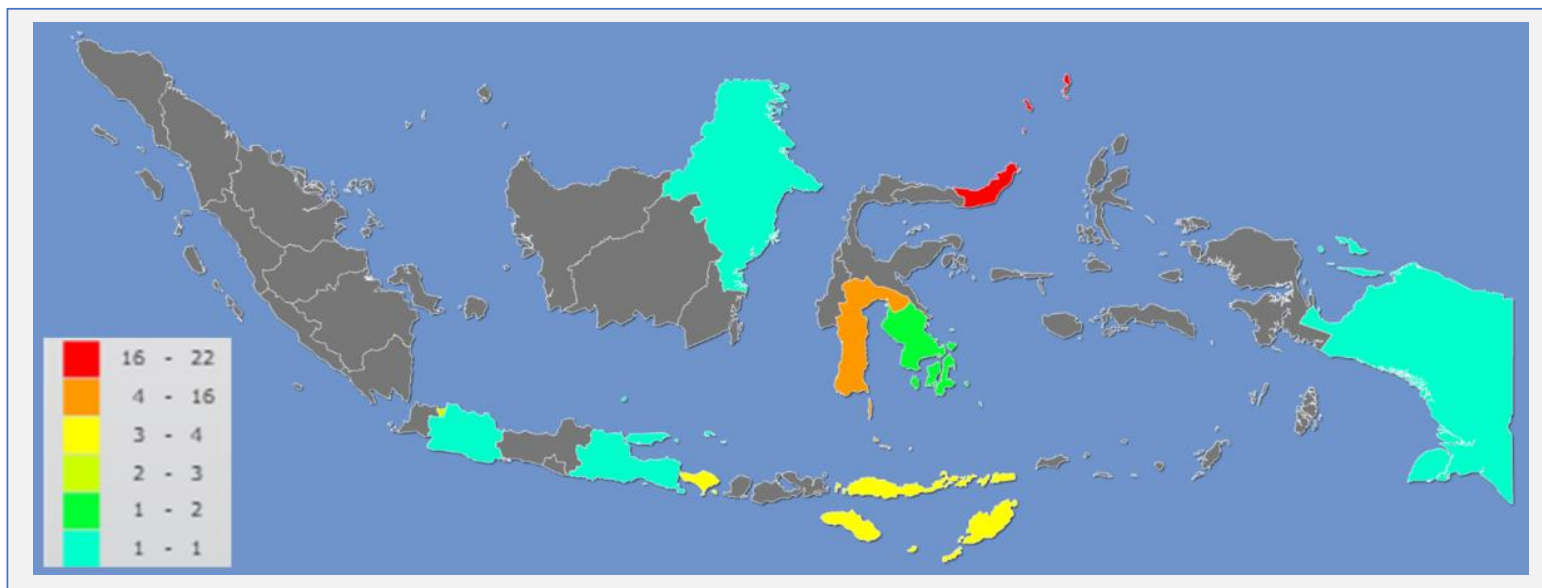

Figure 1.7. Frequency of marine natural products research from new and novel compound from Indonesia based on provinces (see Appendix A for the details); the number indicates total papers published.

Two new sesquiterpenoids, boneratamides-A (22) boneratamides-B (23, Figure 1.8), have been isolated from the marine sponge Axinyssa aplysinoides collected in South Sulawesi. ${ }^{35}$ A few secondary metabolites were isolated from North Sulawesi sponges, for example a peptide, microspinosamide (24, Figure 1.8), which contains 13 amino acid residues, was isolated from Sidonops microspinosa. ${ }^{36}$ 

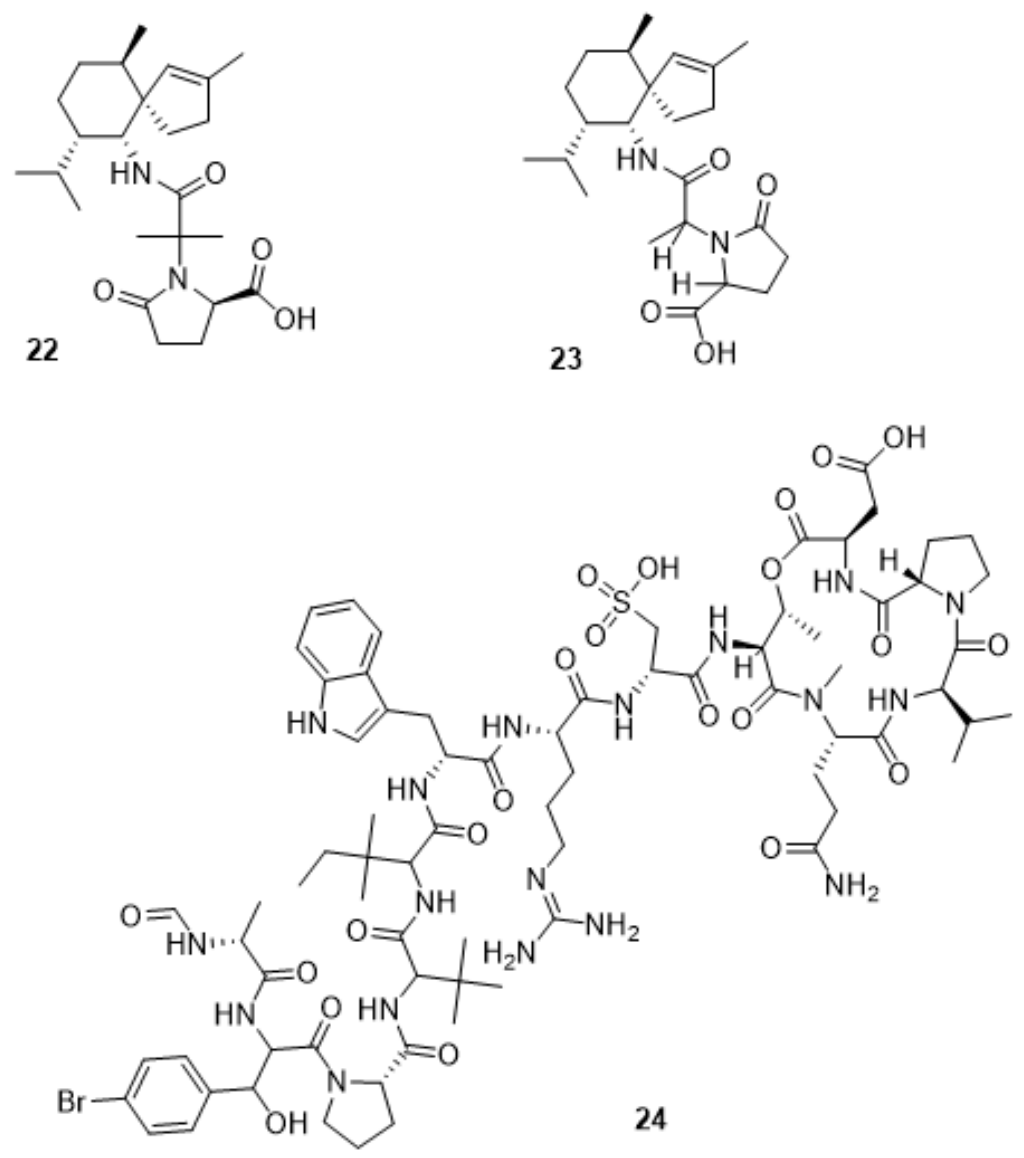

Figure 1.8. Chemical structure of boneratamides-A (22), boneratamides-B (23), microspinosamide (24)

Both organic and aqueous extracts of microspinosamide showed anti-HIV-1 activity at a concentration of $0.12 \mu \mathrm{M} .{ }^{36}$ Other metabolites, manadomanzamines A (25) and B (26, Figure 1.9) isolated from Acanthostrongylophora sp., were also showed activity against HIV-1 with $\mathrm{EC}_{50}$ values of 11.5 and $27.0 \mu \mathrm{M}$ respectively. ${ }^{37}$ Manadomanzamines also exhibited strong activity against Mycobacterium tuberculosis. ${ }^{38}$ Two new imidazole alkaloids, naamidines $\mathrm{H}$ (27, Figure 1.9) and I (28, Figure 1.9), were isolated from the marine sponge Leucetta chagosensis ${ }^{39}$ (see Table 1-3 in Appendix A for a complete list of MNPs research in Indonesia). 


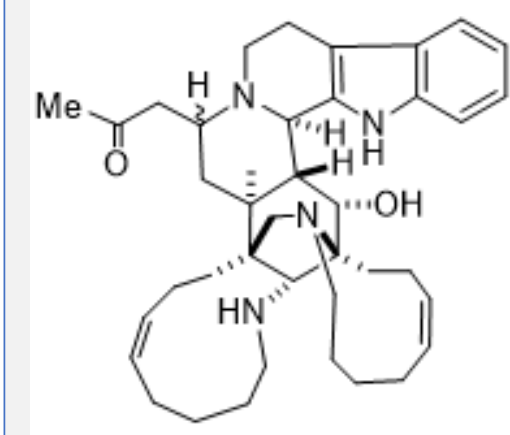

$25(\mathrm{H}=$ beta)

26 ( $\mathrm{H}=$ alpha $)$

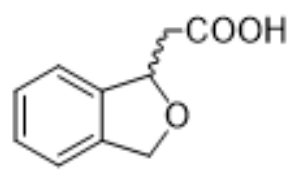

29<smiles>COc1ccc(Cc2nc(NC3=NC(=O)N(C)C3=O)n(C)c2Cc2cc(OC)c(O)c(OC)c2)cc1</smiles>

27<smiles>CN=C1N=C(Nc2nc(Cc3ccc(OC)cc3)c(Cc3cc(OC)c(O)c(OC)c3)n2C)C(=O)N1C</smiles><smiles>[R]C(=C)CC(=CC)C(=O)O</smiles>

$30\left(\mathrm{R}=\mathrm{CH}_{2} \mathrm{OH}\right)$

$31\left(\mathrm{R}=\mathrm{CH}_{2} \mathrm{OC}(\mathrm{O}) \mathrm{CH}_{3}\right)$<smiles>[X]C(CC(=O)O)CC(=O)OC(C)Cc1cc(O)cc(O)c1C(=O)O</smiles>

$32(\mathrm{X}=\mathrm{H})$

$33(\mathrm{X}=\mathrm{OH} ; \mathrm{a}, \mathrm{b}-\mathrm{Cis})$

$34(\mathrm{X}=\mathrm{OH} ; \mathrm{a}, \mathrm{b}-$ trans)

Figure 1.9. Chemical structure of manadomanzamines $A(25)$, manadomanzamines $B(26)$, naamidines $H$ (27), naamidines I (28), herbaric acid (29), Sumiki's acid (30), acetyl Sumiki's acid (31), xestodecalactones $\mathrm{A}, \mathrm{B}$, and C (32-34)

Furthermore, two metabolites were isolated from Cladosporium herbarum (symbiont of the sponge Callyspongia aerizusa) namely, a new phthalide herbaric acid (29, Figure 1.9), which showed no activity, and furan carboxylic acids: Sumiki's acid (30) and acetyl Sumiki's acid (31, Figure 1.9), which both showed activity against Bacillus subtilis and Staphylococcus aureus. ${ }^{40}$ Another fungus collected from Bali, Penicillium cf. montanense, also extracted from a sponge (Xestospongia exigua), is a 10-membered macrolides with a fused 1,3dihydroxybenzene ring xestodecalactones A-C (32-34, Figure 1.9), of which only (33) was active against $C$. albicans. ${ }^{41}$

\subsection{Macroalgae natural products}

Commonly known as seaweed, marine macroalgae has historically been sources of edible seaweed ${ }^{42}$ and raw materials for primary metabolites including gelatin, gellan, pectin, agar, carrageenan, and alginate. ${ }^{43}$ Edible seaweed has been consumed primary by Asian cultures, where species such as brown algae (Fucus vesiculosus, Kombu-Laminaria digitate, and Wakame-Undaria pinnatifida) and red seaweeds (Nori-Porphyra tenera) have been commercially produced. Algae have been utilized to more extensive food products, for example jam, cheese, wine, 
tea, soup and noodles in Japan. ${ }^{44}$ The hydrocolloidal properties of seaweed are exploited as thickening agents and gelling agents in various uses such as salad dressings, sauces and toppings, jelly, marmalade, restructured foods and low sugar/calorie gels. ${ }^{43}, 45$

Macroalgae are found as sessile organisms in intertidal habitats, which is the area between high and low tides. Therefore make marine macroalgae are exposed periodically to both biotic and abiotic stressors. ${ }^{46-48}$ The stresses range from herbivorous fish predation, competition, and disease to various environmental conditions (high and low temperature, desiccation, and osmotic stress). ${ }^{47}$ Active compound defences are used to fight against pathogens and bio-foulants, ${ }^{49}$ colonization/biofilms on seaweeds and bacterial signalling. ${ }^{50-51}$ The various ecological situations force macroalgae to develop a chemical defence mechanism through production of bioactive secondary metabolites. This fact along with their ubiquitous and accessible habitats led natural products chemists into study marine macroalgae as the first group amongst other marine organisms.

The classification of secondary metabolits from macroalgae is derived from their biosynthetic origin. Terpenes are the largest and most diverse class of compounds derived from macroalgae. Terpenes, of which the name can be used interchangeably with terpenoids, make up approximately half of the active compounds found from algae. ${ }^{51}$ Together with polyketides, amino acid derivatives (including non-ribosomal peptides and simple amino acid derivatives), and alkaloids, they encompass almost a quarter of known algae active compounds. Shikimates, usually found in aromatic natural products, are the next largest group of natural products, and the last group consists of various classes of secondary metabolites that are infrequently found in macroalgae, such as nucleosides and other classes of compounds bound to sugars. 


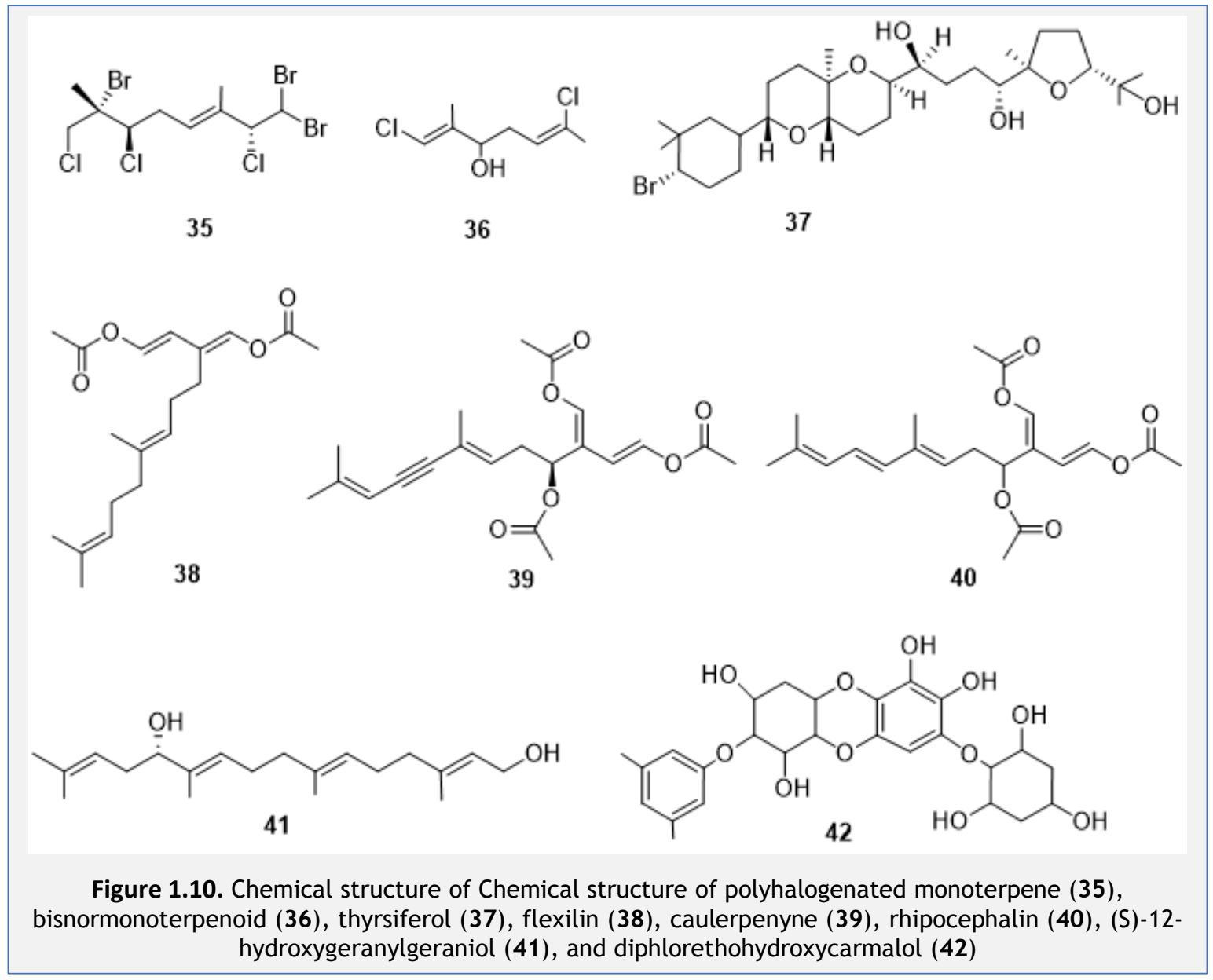

The first study of red algae was reported by Blunt and co-workers, who isolated a polyhalogenated monoterpene (35, Figure 1.10) and a bisnormonoterpenoid (36, Figure 1.10) from Plocamium cruciferum in 1978.52 Also, they found the uncommon squalene derived metabolite, thyrsiferol (37, Figure 1.10), from the red alga Laurencia thyrsifera. ${ }^{53}$ Early studies found the simplest form of 1,4diacetoxybutadiene in a green algae sample, namely flexilin (38, Figure 1.10) isolated from Caulerpa flexilis in 1978. ${ }^{54}$ Two metabolites, caulerpenyne (39, Figure 1.10) and rhipocephalin (40, Figure 1.10), were isolated from Caulerpa prolifera and Rhipocephalus phoenix, respectively. Meanwhile, secondary metabolites from brown algae are predominantly terpenes and polyphenols. For example, the diterpene (S)-12-hydroxygeranylgeraniol (41, Figure 1.10) was isolated from the brown alga Bifurcaria bifurcate collected off the Atlantic coast from Morocco, ${ }^{55}$ and diphlorethohydroxycarmalol (DPHC) (42, Figure 1.10) was isolated from Ishige okamurae, collected along the coast of Jeju Island, Korea. ${ }^{3}$ DPHC was shown to be active against postprandial hyperglycemia in diabetic mice, as well as a potent $\alpha$-glucosidase and $\alpha$-amylase inhibitor. 


\subsection{Macroalgae natural product in Indonesia: status and potential}

Indonesia is one of the richest countries in the world for marine species. About 45\% of the world's marine algae species are found in Indonesia, including 196 green algal species, 134 brown algal species, and 452 red algal species. ${ }^{56}$ Algae species are mainly spread across the central and eastern parts of Indonesia such as Sulawesi, Bali, Nusa Tenggara, and Maluku. Due to this high diversity of marine macroalgae, eastern parts of Indonesia are commonly referred to as "the barn of seaweed." However, according to the algaebase database (http://www.algaebase.org), less than one percent of marine algae have been reported from Indonesia (out of more than 360,000 records of known algae worldwide). ${ }^{57}$

Owing to this highly abundant resource, the phycocolloid industry produces polysaccharide compounds (primary metabolite) from seaweed and has been established in Indonesia to support many coastal communities around those aforementioned areas. A few important species that have been cultivated, namely Kappaphycus alvarezii, Eucheuma spp., and Gracilaria sp, are the major contributors to dry seaweed production in Indonesia. In fact, Indonesia has been the largest producer of seaweed farming since 2014 when its share of global production increased dramatically from 6.7 percent in 2005, to 36.9 percent. ${ }^{58}$ However, little attention has been given to Indonesian algae as a source of pharmacological supply, and only a few studies have been conducted on this topic in Indonesia. Most of the research has conducted focused on red algae species, for example, Vidalia sp. and Gracilaria asiatica which a phenolic vidalenolone (43, Figure 1.11) and a cyclopropyl gracilarioside (44, Figure 1.11) respectively, isolated from these algae. ${ }^{59-60}$ Gracilarioside was found to be mildly cytotoxic to the human A375-S2 melanoma cell line. 

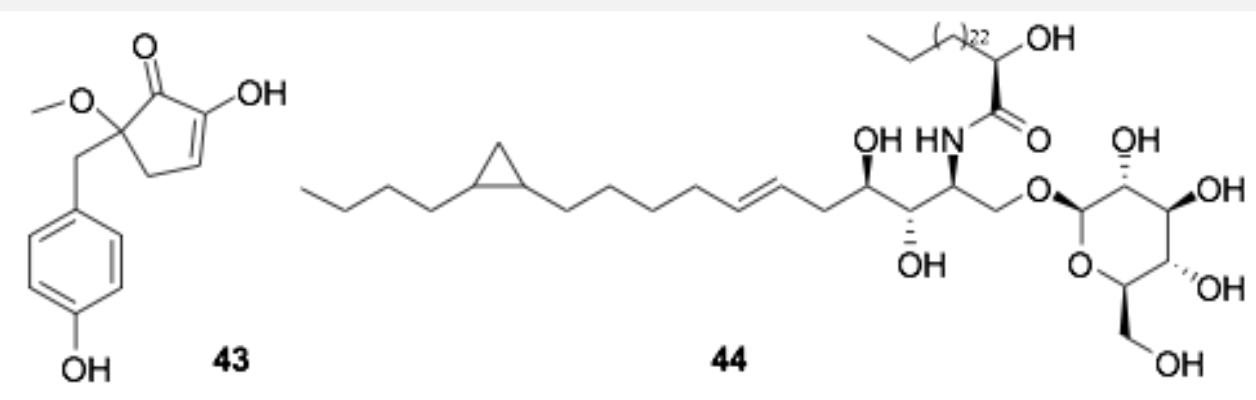

Figure 1.11. Chemical structure of vidalenolone (42) and gracilarioside (44)

One of the most significant issues in marine pharmacological research is the supply of raw materials. Even production of active metabolits on the gram scale is difficult to achieve from natural sources. ${ }^{20}$ Therefore, most of the clinical investigations from marine secondary metabolites are supplied from chemical synthesis. ${ }^{11}$ This problem may be addressed by a greater supply of macroalgae. Once a novel compound has been isolated from macroalgae, the abundance of naturally-occurring macroalgae in Indonesia could support the industry, especially for drug discovery purposes. Furthermore, already established seaweed farms in Indonesia may also sustain this industry from the supply side and best farming practices.

\subsection{Proposed research}

Despite their hugely diverse biogeography and significant potential source for drug development, tropical macroalga natural products have not been extensively studied. This project investigated Indonesian tropical marine macroalgae with the aim of isolating new secondary metabolites.

In Chapter 2, I will discuss about natural product molecular networking may assist the screening of macroalgae.

In Chapter 3, I will focus my research on structure elucidation of a compound resulted from molecular networking screening described in the Chapter 2. 


\section{CHAPTER 2. MOLECULAR NETWORKING TO SCREEN MACROALGAL SECONDARY METABOLITES}

This chapter describes how molecular networking was used as a screening tool to prioritise the isolation workflow of 40 macroalgae sampled from West Timor waters, Indonesia, in addition to a Nuclear Magnetic Resonance-based (NMR) spectroscopy strategy. I describe first the screening and sampling of macroalga for this study. After that, I explain the use of Mass Spectrometry (MS) to generate spectra that were used as data to produce the molecular network with the Global Natural Product Social Molecular Networking (GNPS) website. Next, I show the screening process using the molecular network which assisted in the selection of six samples of macroalgae out of the 40 samples for further examination. After that, I explain the importance of column chromatography in the screening process. Lastly, the final part of the chapter discusses the screening process using an NMRbased protocol to choose the samples of interest to be investigated further.

\subsection{Screening and dereplication of secondary metabolites}

After an organism has been chosen as a species of interest, the next step is preliminary solvent extraction which results in crude extracts (these are described more in section 2.4). Once the crude extracts are obtained, various screening methods are employed to highlight those worthy or more in-depth investigation. The traditional approach has been bioassay-guided screening, which will usually lead to the isolation of biologically active compounds. ${ }^{61-63}$ Although the bioassayguided screening eventually produces a potential pharmaceutical compound, the frequent re-isolation of previously known metabolites is a major challenge for this strategy.62, 64 Alternative approaches namely spectroscopy-guided screening utilising NMR spectroscopy or MS coupled with liquid chromatography (LC-MS) have been introduced as screening tools. This newer strategy combined with high quality spectral databases can help identify known compounds present in the extracts or active substances that have already been studied. ${ }^{64-65}$ The procedure is known as dereplication, a term first coined in the CRC Handbook of Antibiotic Compounds published in 1980.65 Dereplication provides rapid identification of known compound within crude extracts or semi-purified mixtures, facilitating 
prioritisation for further elucidation of only potentially new structures or halting an isolation process of known secondary metabolites. ${ }^{65-66}$ Hence, dereplication is a substantial and important strategy in natural products screening.

\subsection{Isolating secondary metabolites}

Secondary metabolites are typically amphiphilic, which allow the compounds to transverse both hydrophilic and hydrophobic environments. Their wide polarity and solubility make it difficult to analyse and handle the compounds, which may be present in the initial purification of a crude extract. In particular, finding single solvents that will dissolve all the components of a mixture is difficult, if not impossible without some level of pre-fractionation. Preliminary purification steps have commonly been done via liquid/liquid partitioning. However, as some extracts may form stable emulsions, ${ }^{67}$ leading to the incomplete partitioning of the extract and target compounds, as well as the requirement of large volumes of solvent, this straightforward technique has been changed to column chromatography. The widely used reversed-phase chromatography procedure that was developed by Blunt and Munro has been used for many years to overcome problems associated with standard flash column chromatography (normal phase). ${ }^{67}$

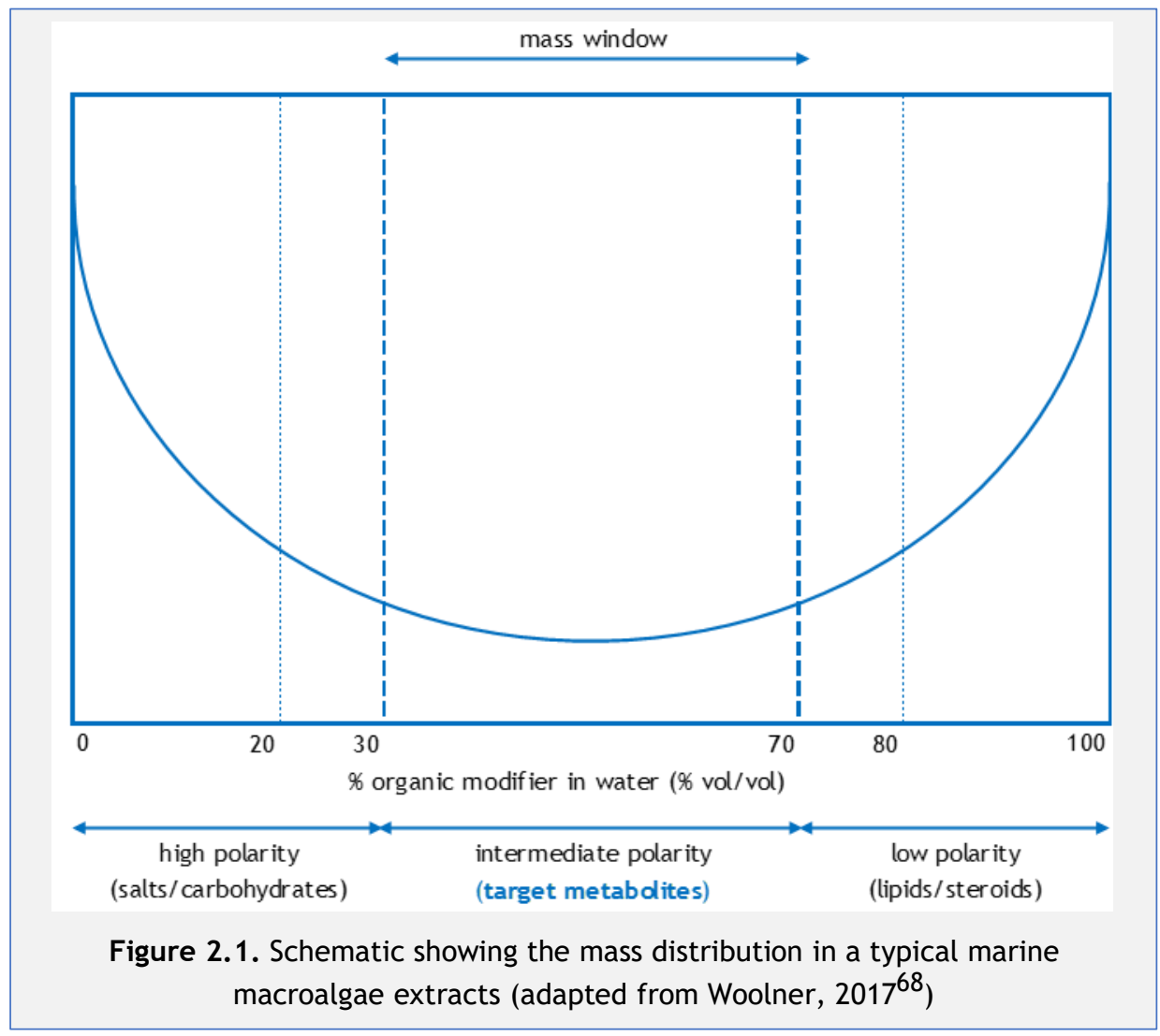


In living systems, most organisms have molecules that are either very non-polar (lipids/steroids) or very polar (proteins/sugars). However, most interesting (amphiphilic) natural products are frequently not discovered with these molecules but in the intermediate "mass window" (Figure 2.1). ${ }^{68}$

At Victoria University of Wellington (VUW), the reversed-phase poly-styrene divinylbenzene (PSDVB) copolymer (HP20) was found to have the advantage of being a relatively inexpensive adsorbent, stable throughout the $\mathrm{pH}$ range, and reusable unlike silica gel (normal phase). Also, acetone and methanol, environmentally friendly solvents, are widely used for this technique which gives an additional advantage. This method is known as cyclic loading and has benefited the natural product research group at VUW for quite some time now. The cyclic loading system enables crude extracts to be loaded directly onto the PSDVB column without the need for preconcentration.

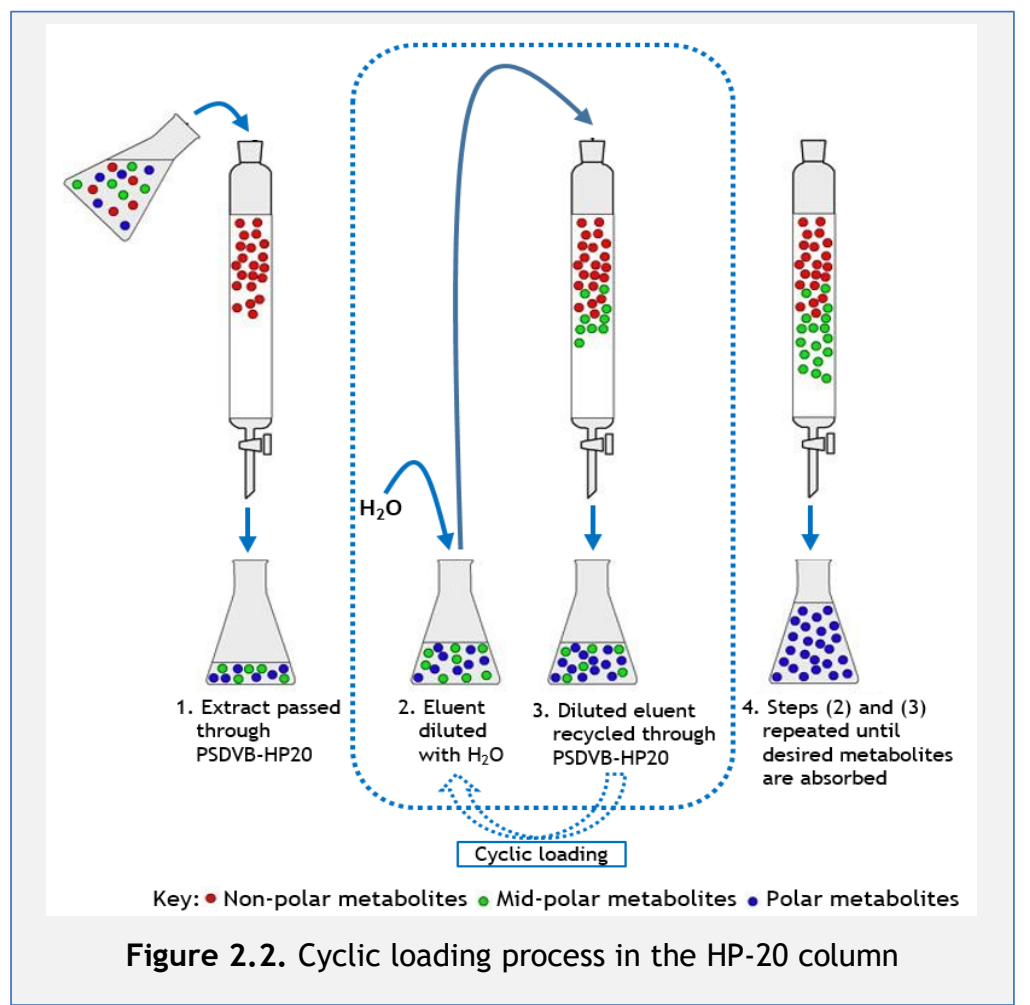

The cyclic loading starts by firstly passing the crude extracts through the PSDVBHP20 column (Figure 2.2). The next step is to dilute the eluent with water and recycle back onto the column. Normally dilution with water would cause irreversible precipitation of extracted non-polar materials, but these compounds will already have adsorbed to the column and are no longer present. The dilution and recycling is repeated three to four times. By adding the water to eluent, 
typically an equal volume of $\mathrm{H}_{2} \mathrm{O}(100 \% \mathrm{v} / \mathrm{v})$, it gradually increases the polarity of eluent which leads to more mid-polar compounds having greater affinity and adsorption onto the PSDVB.

Once the cycle is completed, the last step is to wash the column with $\mathrm{H}_{2} \mathrm{O}$ to remove salts. The next phase is complete elution using an organic solvent (usually acetone, $\mathrm{Me}_{2} \mathrm{CO}$ ). Previous research at VUW has suggested that the target metabolites elute mostly in the intermediate $30-75 \%$ acetone in water fractions. In this study a series of solutions was used as follows: (1) $30 \% \mathrm{Me}_{2} \mathrm{CO} / \mathrm{H}_{2} \mathrm{O}$, (2) $75 \%$ $\mathrm{Me}_{2} \mathrm{CO} / \mathrm{H}_{2} \mathrm{O}$, and (3) $100 \% \mathrm{Me}_{2} \mathrm{CO}$. While the $100 \% \mathrm{Me}_{2} \mathrm{CO}$ fraction can be immediately concentrated under reduced pressure, but the $30 \%$ and $75 \%$ fractions contain too much water for concentration, some $\mathrm{H}_{2} \mathrm{O}$ /organic modifier mixtures froth vigorously under vacuum. These fractions must be further processed via back loading.

Back loading involves cyclic loading the eluted fraction by diluting with water and passing it through a small PSDVB-column. This causes the eluted compounds to readsorb to the column. The column can then be stripped with a pure organic solvent, thereby removing the water from the sample and generally also concentrating the fraction as well. Both the $30 \%$ and $75 \% \mathrm{Me}_{2} \mathrm{CO}$ fractions are back loaded onto separate PSDVB columns. After the first back loading, the eluent is diluted with water $(100 \% \mathrm{v} / \mathrm{v})$ and back loaded into the column (the step is repeated thrice). Before the final $100 \% \mathrm{Me}_{2} \mathrm{CO}$ is used to elute the PSDVB column, the column is blown dry to reduce the amount of water present in the column. Then, the fractions are converted to only $\mathrm{Me}_{2} \mathrm{CO}$ and the eluents can be concentrated under reduced pressure.

Popplewell, ${ }^{69}$ who previously studied 34 temperate New Zealand red algae in the marine natural products group at VUW, developed a method for algal screening that was modified from VUW in-house protocols designed for the screening of sponge extracts. ${ }^{69-70}$ The protocol involves the extraction from $2 \mathrm{~g}$ or more (wet weight) algal material because macroalgae have a richer fraction of secondary metabolites, compared to sponge extracts which typically require $\sim 100 \mathrm{~g}$ wet weight. ${ }^{69}$ Since the mid-1990s, the MNPs group at VUW has been utilising NMRguided isolation of secondary metabolites. 


\subsection{Liquid chromatography-mass spectrometry}

MS has become a standard procedure for investigating complex mixtures and molecules. Liquid chromatography coupled with mass spectrometry (LC-MS) is a hyphenated analytical technique that synergises the ability to perform fractionation via liquid chromatography with the mass analysis capability of MS. ${ }^{71}$ This particular technique works by ionisation of a molecule that is then smashed and turned into charged fragments, which then would be quantitated based on their mass-to-charge $(\mathrm{m} / \mathrm{z})$ ratio. ${ }^{72-73}$ An LC-MS system includes elements such as high-performance liquid chromatography (HPLC) system; the ionization source (which interfaces the LC to the MS); and the mass spectrometer. A computer system is used to control all these elements (Figure 2.3). ${ }^{71}$

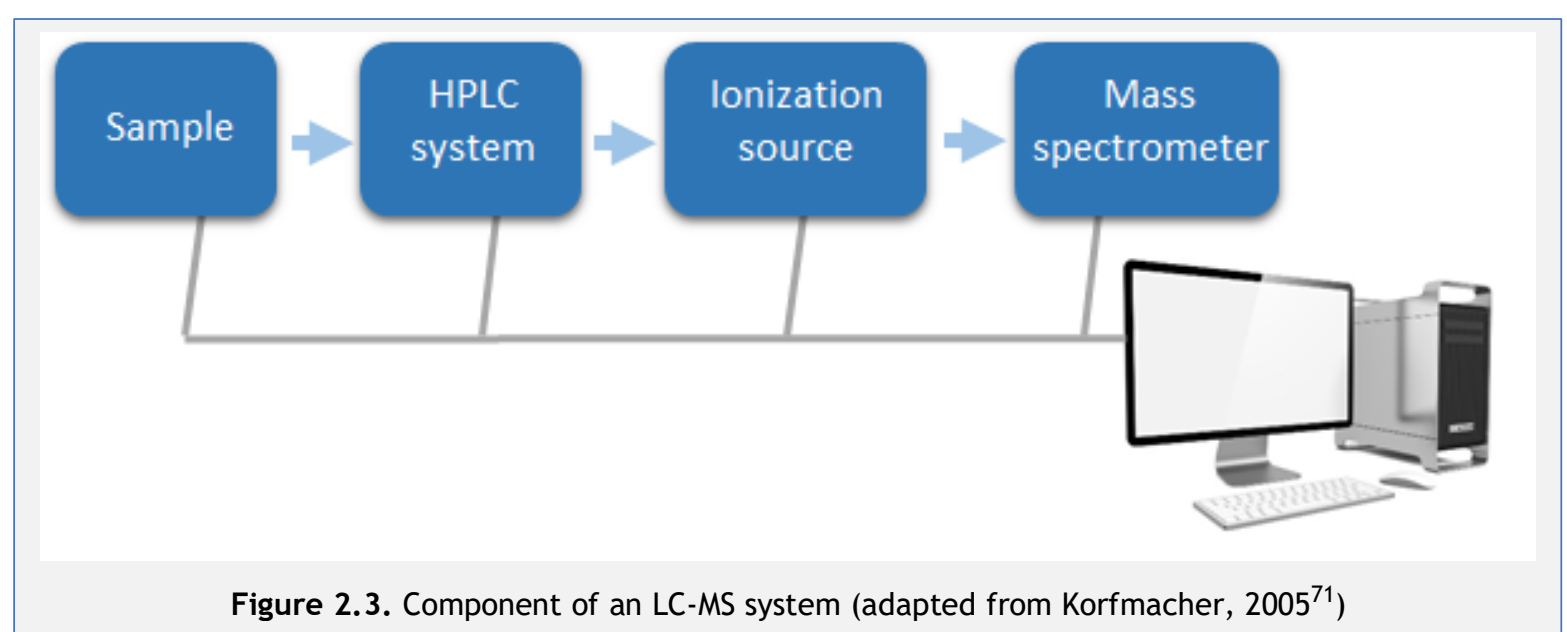

A mixture of water and common hydrophilic solvents (isopropanol, methanol, or acetonitrile) as the mobile phase is prepared by the HPLC system. A pumping mechanism in the HPLC system allows pressurised liquid and a sample mixture to pass through a column filled with the adsorbent stationary phase. The adsorbent is typically a granular material $(1-50 \mu \mathrm{m})$ made of solid particles (typically a silicabased bonded phase e.g. (18). ${ }^{74}$ The ionization source is used as the interface between the HPLC eluent and the mass spectrometer. Two common atmosphericpressure ionisation (API) technique sources are electrospray ionisation (ESI) and atmospheric-pressure chemical ionisation (APCI). The eluent from the $L C$ is nebulised so that ions are produced from the evaporating droplets. Nebulisation is achieved either pneumatically via $\mathrm{APCl}$ or by a strong electrical field in $\mathrm{ESI} .{ }^{74} \mathrm{~A}$ number of mass analysers are available but nowadays time-of-flight (TOF) MS is the most widely used system in drug discovery research. In a quadrupole time-of- 
fight (QTOF) instrument, as used in this study, the quadrupole is used to select precursor ions which will be fragmented later in a collision cell. These generated ions are then spearated by the TOF and detected by a photo-electron multiplier plate. $^{75}$

In natural products discovery, the data produced from tandem MS can be employed as a screening method. It is a robust approach because even a crude extract sample is enough for the screening process (due to the higher sensitivity of the instrument compared to other analytical techniques)..$^{73}$ In this process a molecular network is produced to organise mass spectra into groups based on similarities in their fragmentation patterns with the expectation that structurally related molecules will yield similar spectra. ${ }^{76}$ Therefore, molecular networking using MS can be applied as a data-rich approach that represents an important advance for the field of natural product research.

\subsection{Algal screening through Global Natural Product Social Molecular Networking}

Although a single LC-MS experiment is already a powerful technique that can collect thousands of spectra in a relatively brief time, most of the data is only sitting in the researchers' drawers or computer. Moreover, most natural products databases such as the Dictionary of Natural Products (http://dnp.chemnetbase.com/) and MarinLit (http://pubs.rsc.org/marinlit) only provide services to their subscribers. Recognising this need, the University of California San Diego (UCSD) Centre for Computational Mass Spectrometry (http://proteomics.ucsd.edu) developed Global Natural Product Social Molecular Networking (GNPS) to accommodate the demand for robust dereplication of natural products that is freely available to the global research community. ${ }^{77}$ GNPS is an open database that provides the ability to analyse, organise, and create networks from tandem mass spectra data. ${ }^{77}$ Moreover, the publicly available GNPS database (known as MassIVE) is used to compare experiment data with the known spectra library which is useful for dereplication in natural products. 

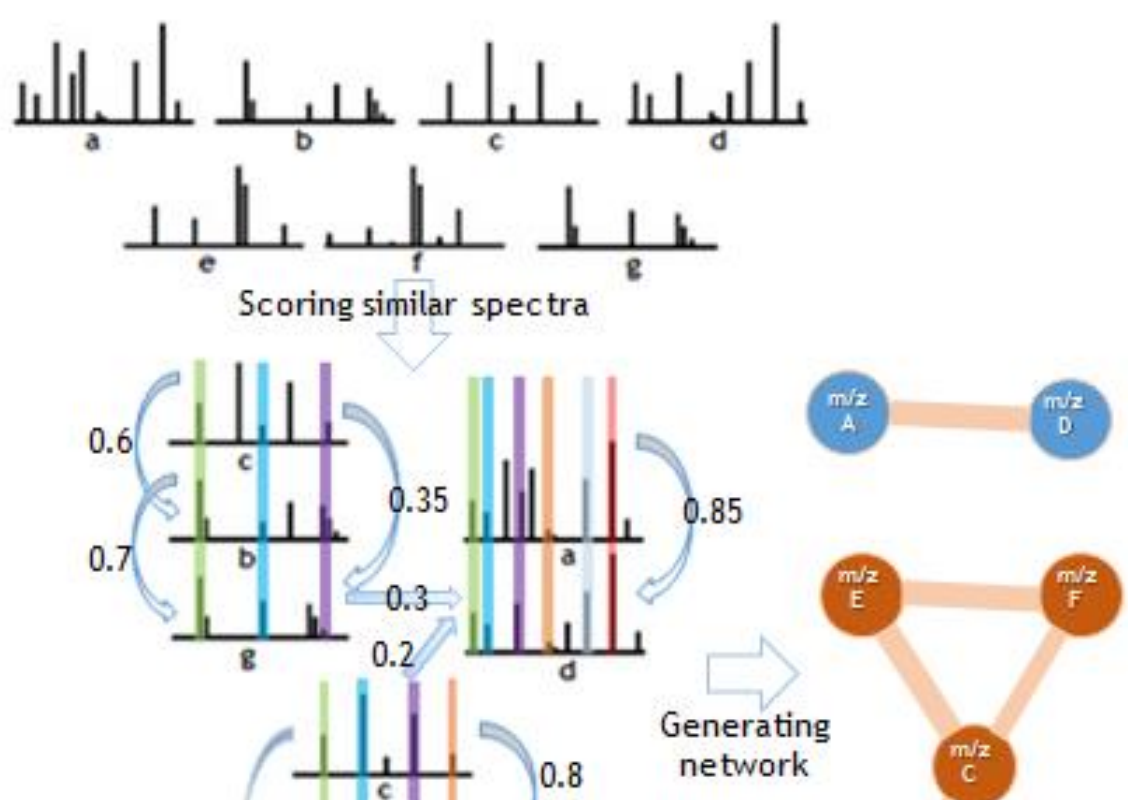

0.7

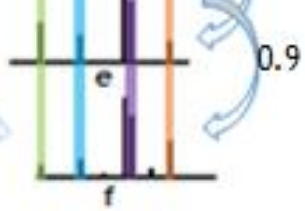
network

Figure 2.4. A scheme shows how molecular networks are created from LC-MS data (Modified from Watrous, et al., used by permission) ${ }^{78}$

Instead of a linear comparison, GNPS uses a vector-based approach to match two or more different MS/MS spectra (see Figure 2.4 for details). Experimental mass spectra with unique fragmentation patterns are combined into multidimensional vectors. Vectorisation in GNPS happens by taking not only the intensity of the peak but also the mass-to-charge ratio of the ion $(\mathrm{m} / \mathrm{z})$. An overall vector is generated by plotting the $\mathrm{m} / \mathrm{z}$ ratio of multiple peaks $(n)$ in $n$-dimensional space. Each overall vector represents a compound or potentially isomers and will be shown as nodes. The overall vectors of different compounds can be aligned and compared with each other, thus the cosine of the angle between two or more vectors can be used to measure their similarity. The cosine score represents how closely related two nodes (hence compounds) are, which varies from 0 (completely unrelated) to 1 (identical spectra). In the network, the cosine score is usually represented by the thickness of a line (edge) that connects two nodes.

A cluster is formed when nodes are connected by edges and comprises a unique set of molecules which are related as structurally similar compounds tend to have similar properties and belong to the same group. ${ }^{79-80}$ GNPS also enables annotation 
of putative nodes, therefore the mass difference can be used to annotate other nodes. ${ }^{81}$

GNPS provides network visualisation on their website (https://gnps.ucsd.edu/ProteoSAFe/static/gnps-splash2.jsp). However, a more sophisticated third-party software, called Cytoscape, is available to visualise the network (http://www.cytoscape.org). ${ }^{82-83}$ In this open-source freeware, visualisation of key defining attribute values in the network are shown in different shapes, colours, and sizes. ${ }^{84}$ Cytoscape is a reliable tool for displaying large data sets in other areas such as metabolomics, biochemical pathways, population networks and even social science research. ${ }^{85-88}$ The current version of the freeware is Cytoscape v3.7 (released in October 2018).

\subsection{Sampling of Indonesian macroalgal from West Timor}

In this study sampling of Indonesian macroalga was done in two different islands; Timor Island and Semau Island of West Timor waters, Indonesia (Figure 2.5, see also section 5.1). A total of 40 species were collected during low tides (Table 2.1 and Appendix B) and dried under the sun for further extraction. The number of green alga (Chlorophyta) and red alga (Rhodophyta) collected were the same while less brown alga (Phaeophyta) were sampled. Interestingly, Akle Beach in Semau island provided more species of species compared to the other three beaches.

Table 2.1. Number of macroalgal collected on each site based on phylum

\begin{tabular}{lcccc}
\hline Location & $\begin{array}{c}\text { Number of } \\
\text { Phaeophyta } \\
\text { (brown) }\end{array}$ & $\begin{array}{c}\text { Number of } \\
\text { Rhodophyta } \\
\text { (red) }\end{array}$ & $\begin{array}{c}\text { Number of } \\
\text { Chlorophyta } \\
\text { (green) }\end{array}$ & Total \\
\hline Sulamu Beach & 4 & 3 & 2 & 9 \\
Pasir Panjang Beach & - & 4 & 2 & 6 \\
Akle Beach & 4 & 6 & 10 & 20 \\
Tablolong Beach & 2 & 2 & 1 & 5 \\
\hline Total & 10 & 15 & 15 & 40 \\
\hline
\end{tabular}




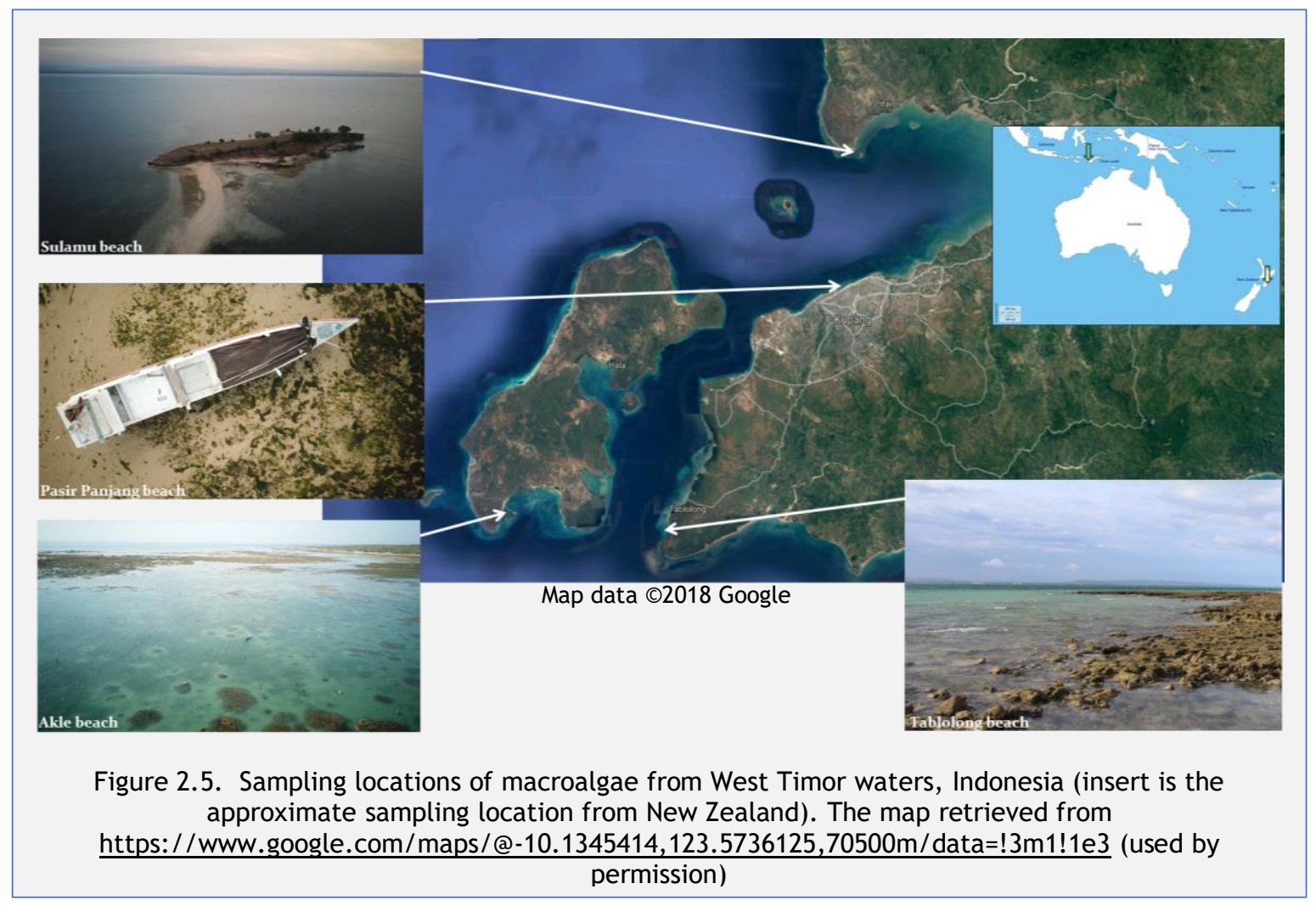

A selected number of specimens were identified using deoxyribonucleic acid (DNA) barcoding to ensure if the species were known or relatively new sources of macroalgae natural products. During sampling, clean apices from algae were rapidly dried and stored in silica gel. DNA extraction was performed at Phycology research group at School of Biology Sciences Victoria University of Wellington with the help of Assoc. Professor Joe Zuccarello. The result showed that the specimen of interest is grouped with only Laurencia snakeyi (Figure 2.6). 


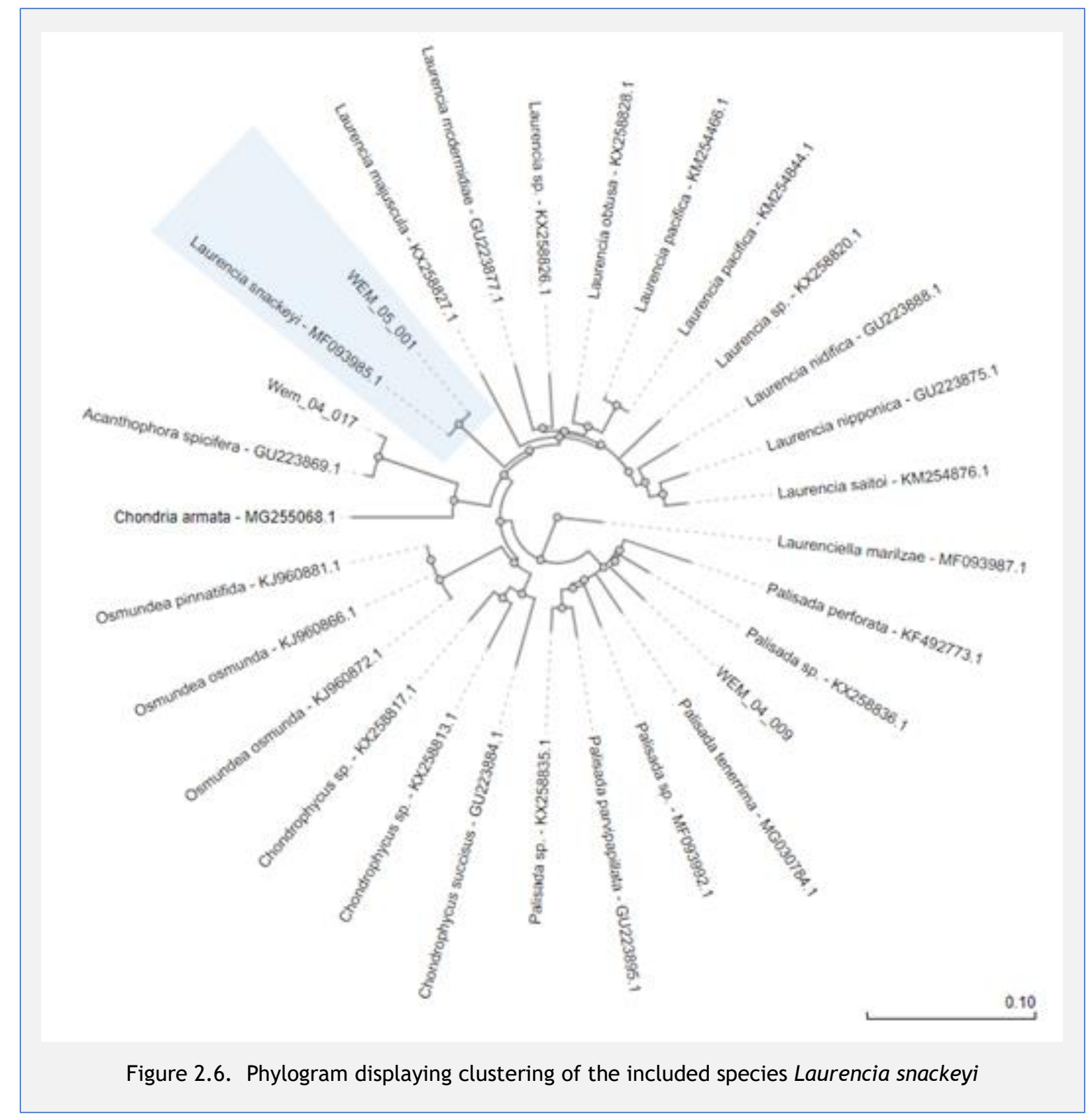

\subsection{LC-MS Screening results of West Timor macroalgal}

The 40 macroalgae samples collected from West Timor waters, in Indonesia, (see Appendix $\mathrm{B})$ were extracted using methanol $(\mathrm{MeOH})$ at room temperature and were dried afterward to obtain a crude extract weight. Prior to LC-MS analysis, all samples were diluted in $\mathrm{MeOH}$ to a set of concentration $\left(0.1 \mu \mathrm{g} \mu \mathrm{L}^{-1}\right)$. In the LCMS, both positive and negative modes were employed to get fragments of the samples based on their $\mathrm{m} / \mathrm{z}$ ratio, in order to maximise the amount of data obtained since some compounds only ionised under one mode.

Spectra data from LC-MS/MS were converted and exported as mgf files to the GNPS website along with text files of meta-data attributes to produce the network. On 
the GNPS website, for each dataset from positive or negative ion mode was run separately. To create consensus spectra, all key parameters were set: parent mass tolerance was set to $0.02 \mathrm{Da}$ and MS/MS fragment ion tolerance was set at 0.02 $\mathrm{Da}$. Also, the consens5us spectra that contained less than two spectra were discarded. The Minimum Pairs Cosines score was set to 0.7 and the minimum fragment ions matched was set to six data to produce the network. The results were then exported and later visualised in the Cytoscape application (version 3.7) and displayed in "preferred layout" settings. Positive mode data showed 574 nodes and 857 edges (Figure 2.7a) while negative mode showed fewer nodes and edges, 120 and 182, respectively (Figure $2.7 \mathrm{~b}$ ).

The positive ion GNPS network shows that macroalgae collected from Akle Beach have potential for further study (Figure 2.7a). The network is dominated by clusters formed from algae collected at Akle Beach (more than 10 clusters), followed by two clusters from Sulamu Beach and Tablolong Beach (which connect to a Sulamu Beach cluster), with no clusters from Pasir Panjang Beach. Akle Beach has the most clusters since 20 out of 40 macroalgae samples were collected from this site. Conversely, in the negative ion mode, no single cluster was formed from algae collected from a specific location (Figure 2.7b), as they have nodes that also belong connect to extracts from to other sites.

However, the negative ion network also confirms that potential macroalgae for screening come from similar beaches as shown in the positive ion mode (i.e., Akle Beach, Sulamu Beach, and Tablolong Beach). This may occur due to the production of secondary metabolites from macroalgae as chemical defences to herbivores. As Pasir Panjang Beach is located in an urban areas, therefore, the absence of herbivory fish in this site might slightly alter the function of secondary metabolites in this particular beach. ${ }^{89-90}$ 


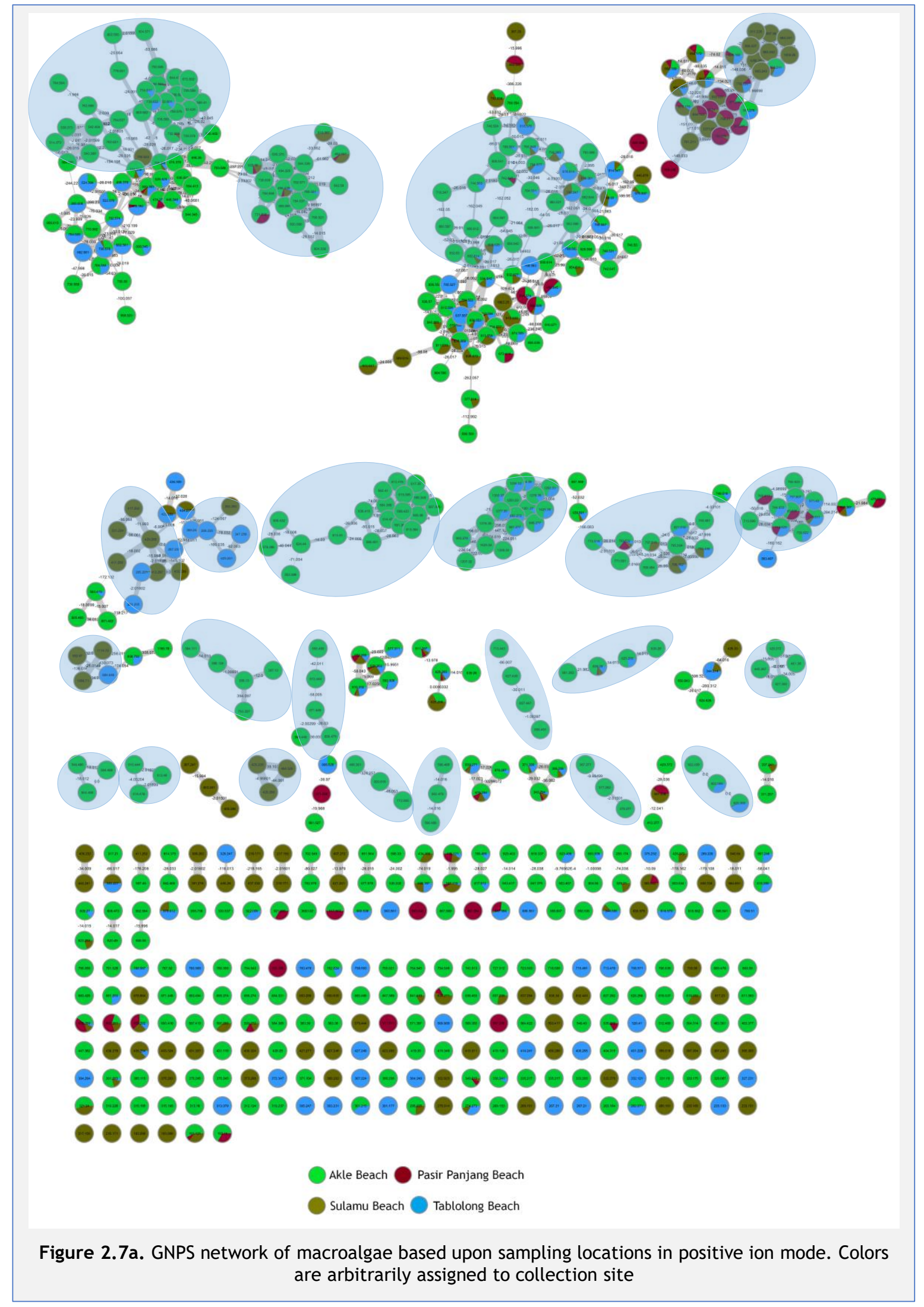




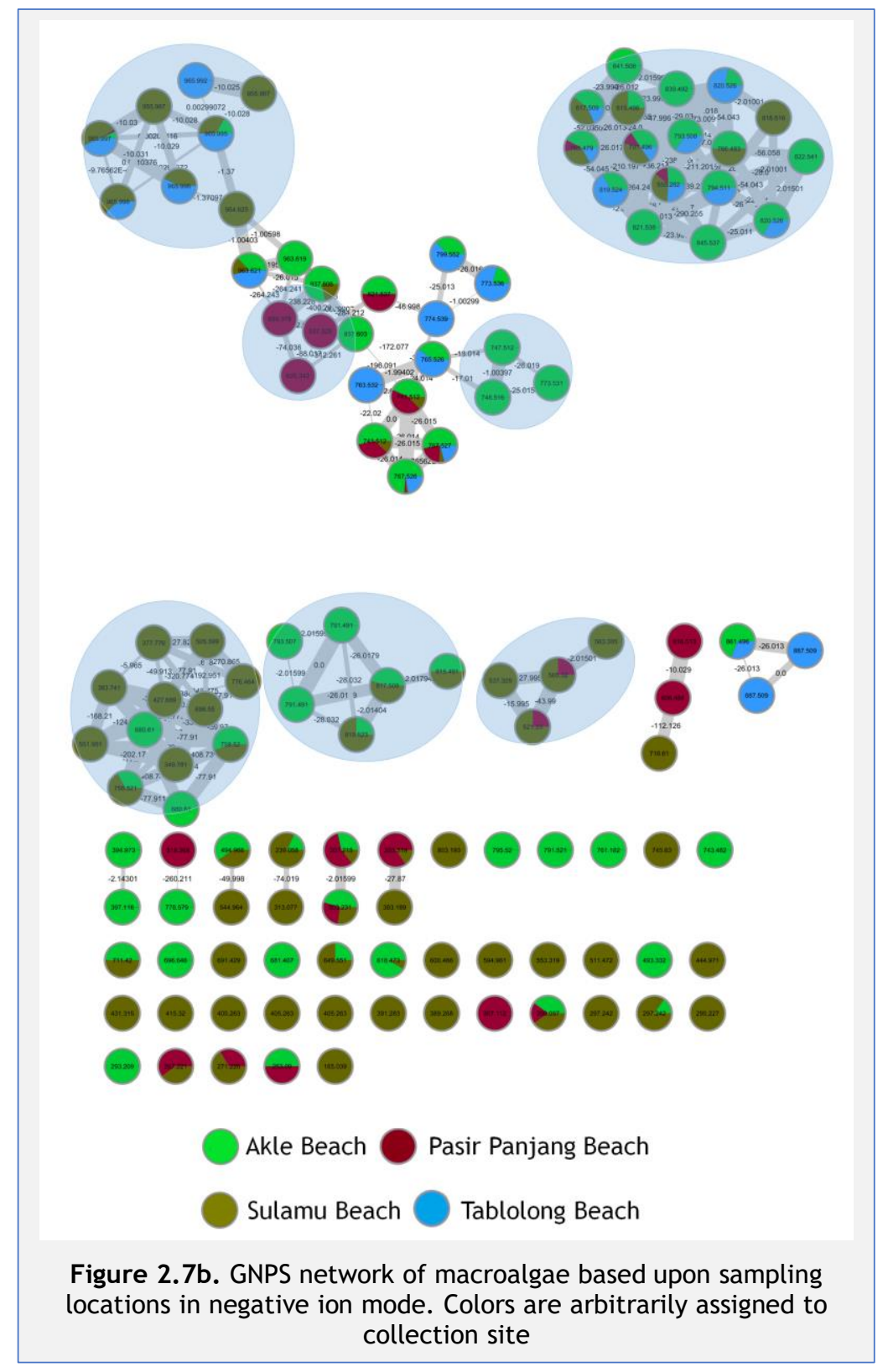

When the phylum of macroalgae is considered for grouping the GNPS network (Figure 2.8), green macroalgae (Chlorophyta) were shown as the most prolific source of compounds followed by brown (Phaeophyta) and red macroalgae (Rhodophyta). Thirteen clusters were formed from green algae while brown and red algae generated nine and seven clusters, respectively. These results contradict the trend in macroalgae secondary metabolites research since the most prolific source of macroalga natural products is red algae which account for more than $50 \%$, followed by brown for almost $40 \%$ and the rest are from green seaweed. ${ }^{16,}$, $91-96$ 


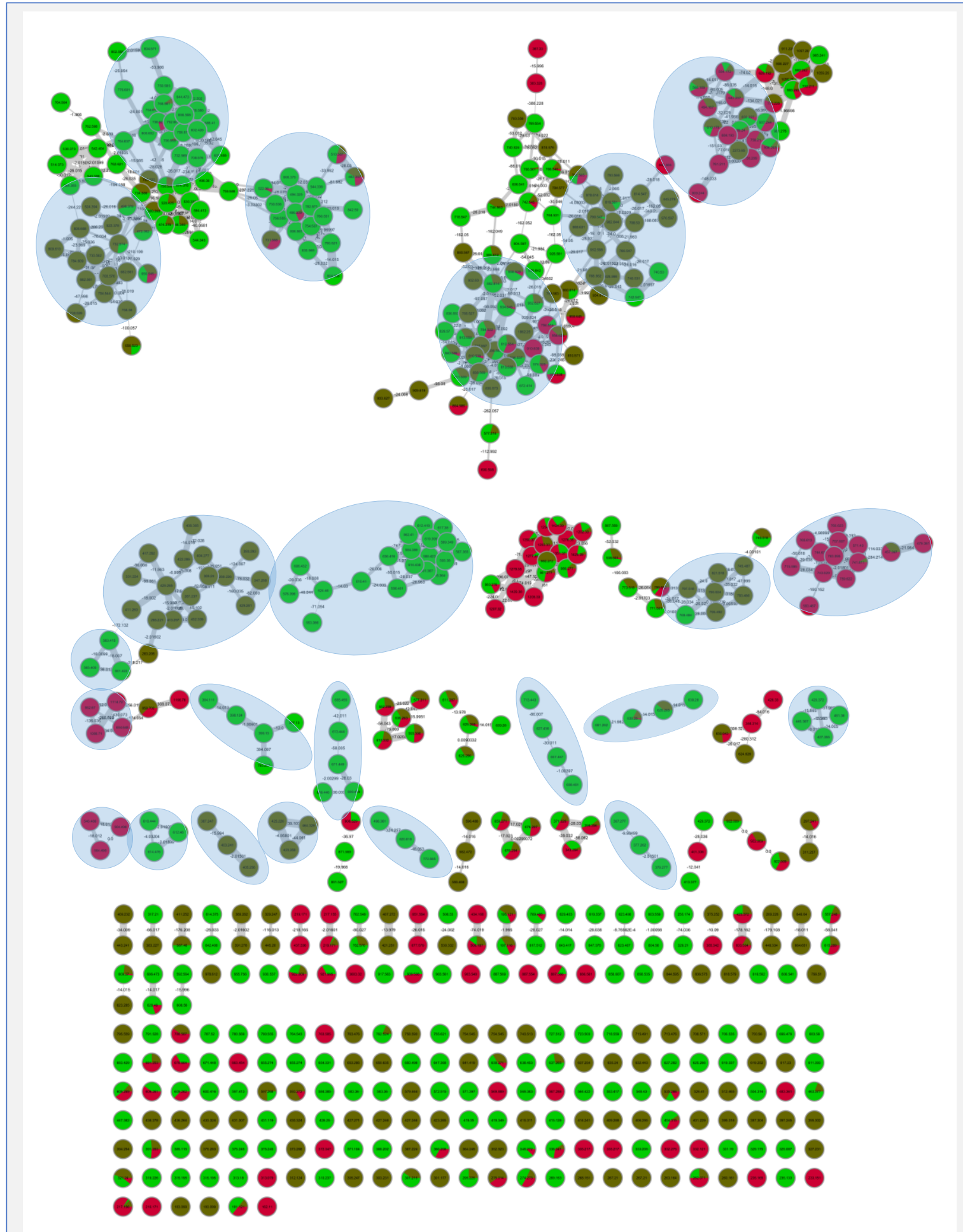

Green Algae (Chlorophyta) Red Algae (Rhodophyta) Red Algae (Phaeophyta)

Figure 2.8a. GNPS network of macroalgae based upon phylum in positive ion mode. Colors are arbitrarily assigned to collection site 


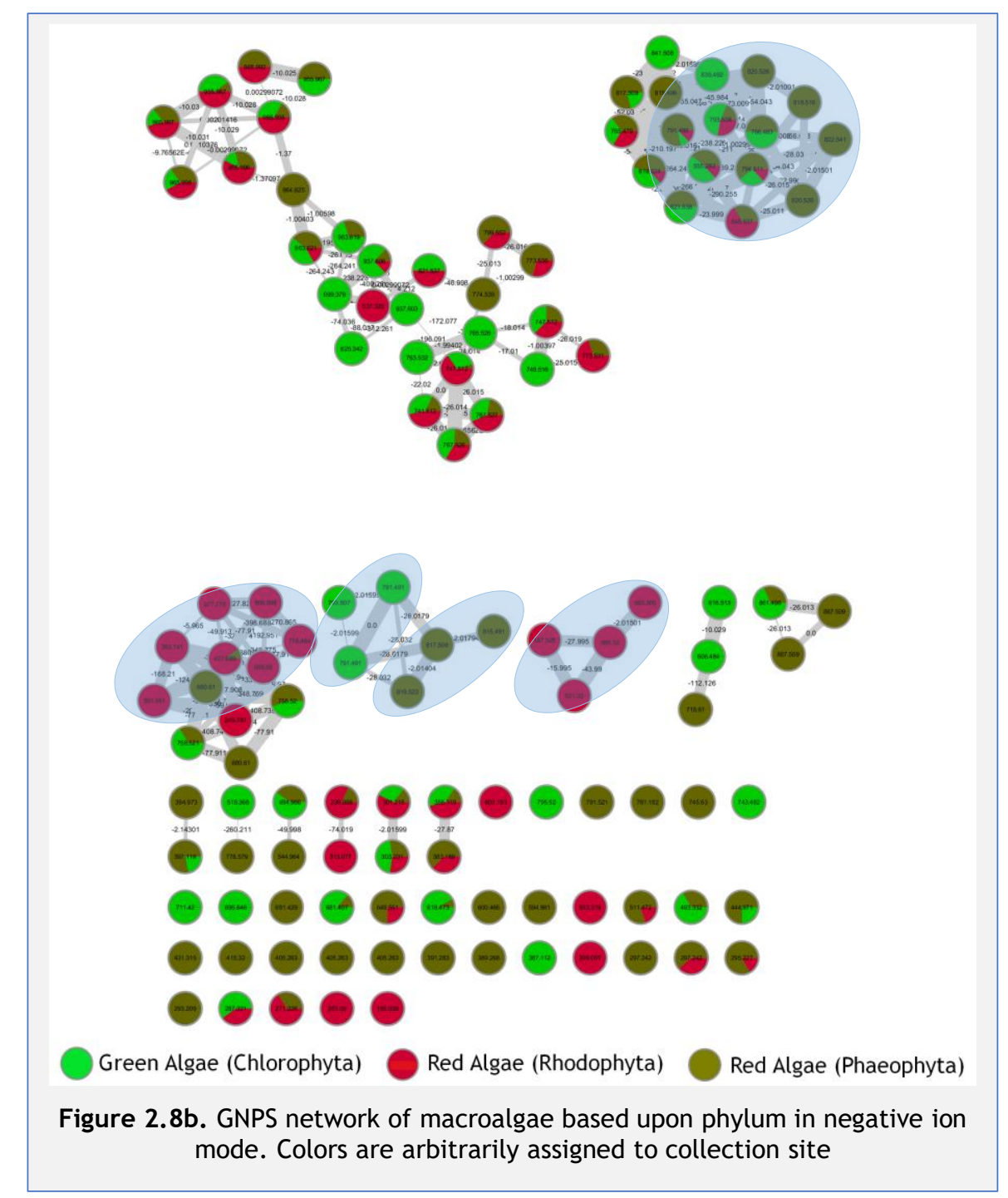

However, seasonal assemblage of intertidal macroalgae in the tropics usually shift to more green and red algae in late of summer/start of the rainy season (mostly between Oct-Dec each year). ${ }^{97}$ The samples collected from West Timor waters found more green and red macroalgal species compared to brown during the OctNov sampling (Appendix B). This result suggested brown algae may be an under studied resource for finding new marine natural products. 
Molecular networking based on individual species enabled a selection of samples to be prioritised in the isolation workflow. From both positive and negative mode networks, six samples were selected to be processed further for NMR screening (Figure 2.9). The samples are: Amphiroa sp1 (WEM_01_005) from Sulamu Beach; Amphiroa sp2 (WEM_03_002), Ulva sp1 (WEM_03_004), and Ulva sp2 (WEM_03_005) from Pasir Panjang Beach; Padina sp2 (WEM_04_019) from Semau Island, Laurencia snackeyi (WEM_05_001) from Tablolong Beach. These samples were selected based on clusters formed where the clusters were dominated by one of the six specimens.

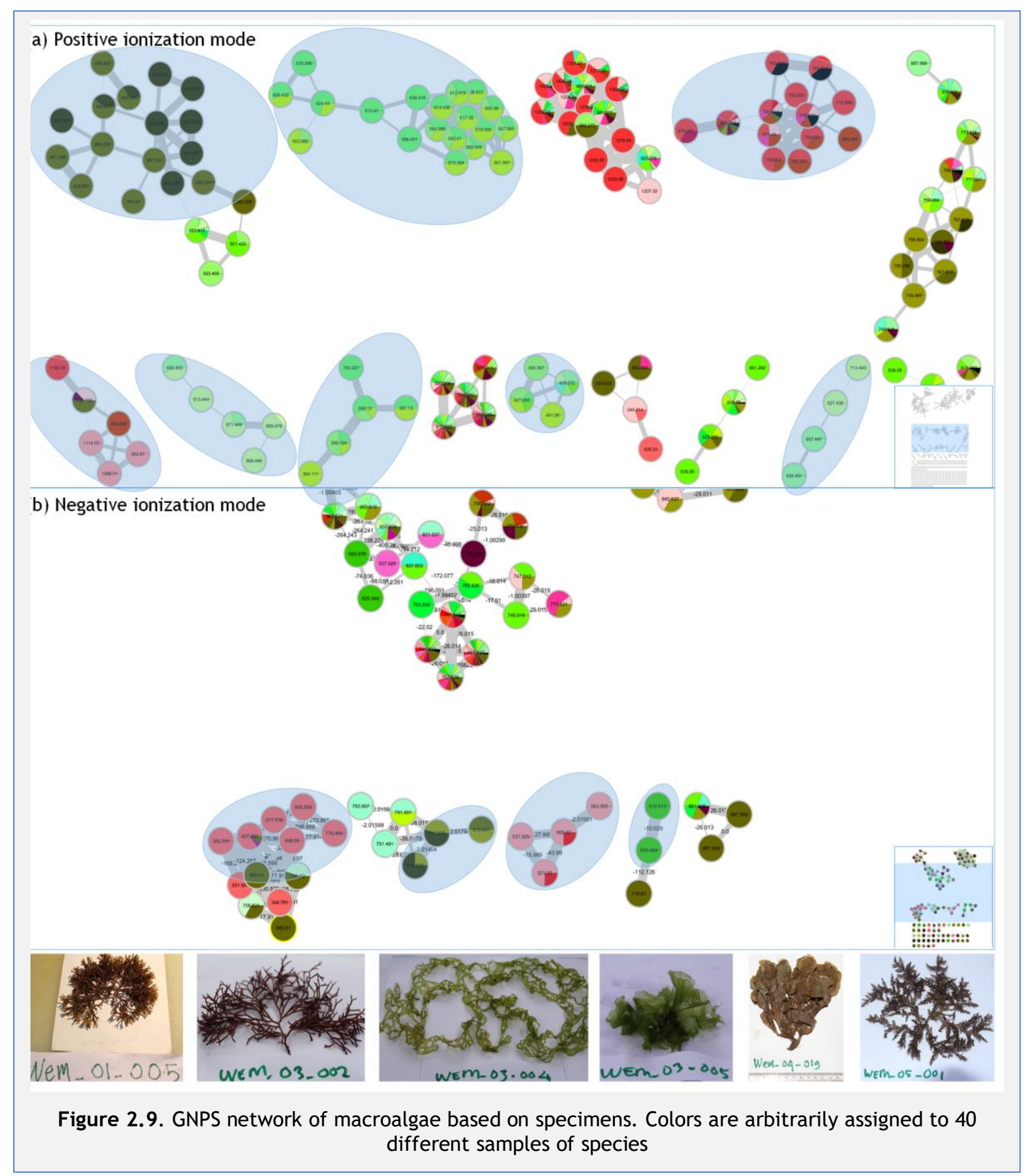




\subsection{NMR-guided screening}

Six extracts that had been prioritised through molecular networking (previous section), were then fractionated before using ${ }^{1} \mathrm{H}$ NMR to verify the presence of interesting secondary metabolites. Although NMR spectroscopy does not offer biological information, it is perceived that novel structures often lead to interesting biological activity. ${ }^{70}$ As argued before, the intermediate $75 \%$ fraction (mass window) showed the most interesting peaks compared to the $30 \%$ and $100 \%$ $\mathrm{Me}_{2} \mathrm{CO}$ fractions.

Out of six samples, three were initially chosen as having interesting peaks between 3.5-5 ppm (Figure 2.10); namely WEM_01_005 (Amphiroa sp1), WEM_04_019 (Padina sp2), and WEM_05_001 (Laurencia snackeyi). The resonances in these downfield correspond to oxymethine protons, predominantly sugars signals. Because of the small amount available, two of the samples were not processed further, and only WEM_05_001 (Laurencia snackeyi) was purified further and will be discussed in the following chapter.

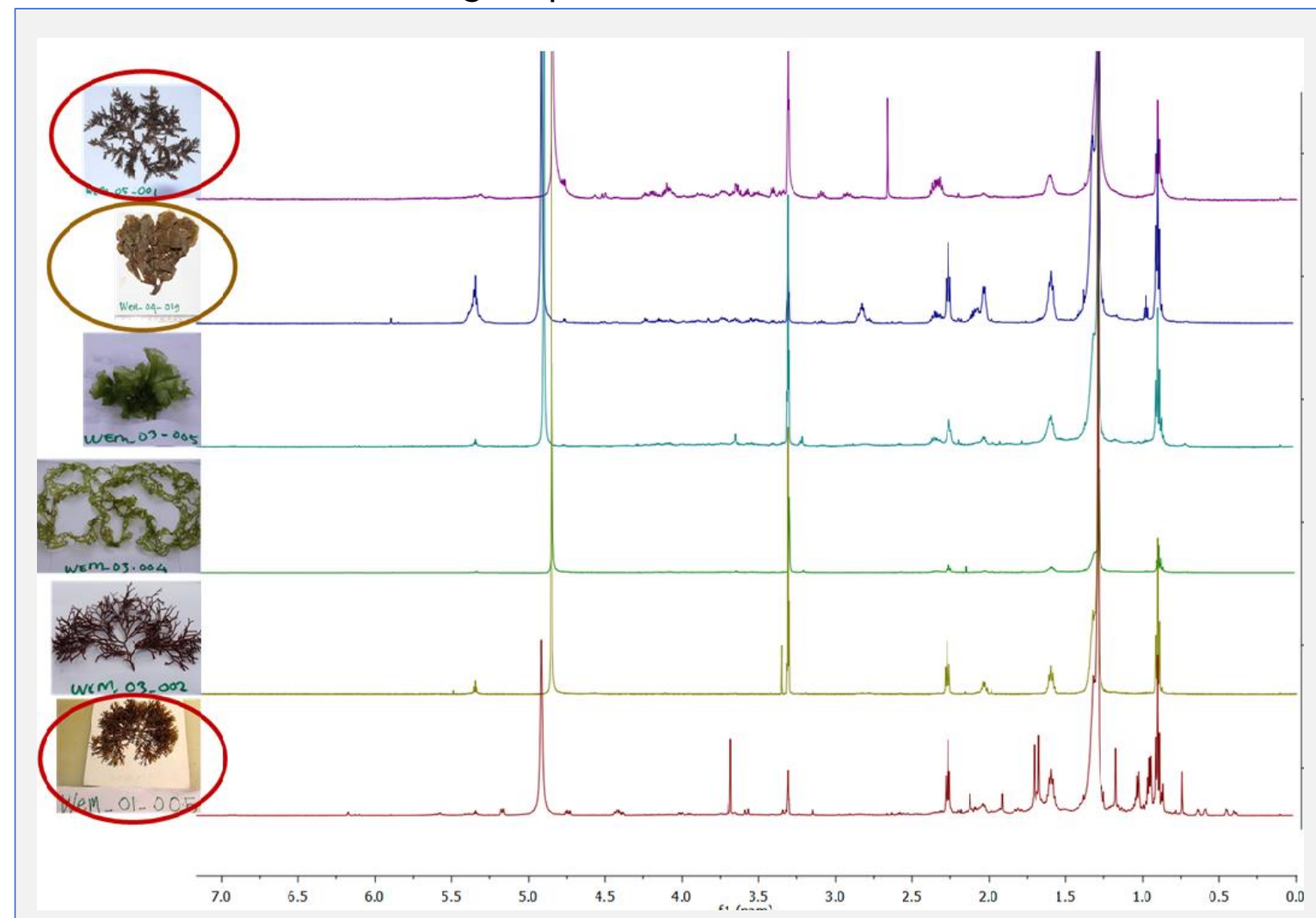

Figure 2.10. ${ }^{1} \mathrm{H}$ NMR spectra from $75 \%$ semi-purified fractions of six prioritized samples of macroalgae $\left(600 \mathrm{MHz}, \mathrm{CD}_{3} \mathrm{OD}\right)$ 


\section{CHAPTER 3. WEST TIMOR MACROALGAE MARINE NATURAL PRODUCTS: Laurencia snackeyi}

\subsection{Introduction}

In Chapter 2, the sample "WEM_05_001" was prioritised for further investigation based upon liquid chromatography-mass spectrometry (LC-MS/MS) and nuclear magnetic resonance (NMR) screening. This alga was identified as Laurencia snackeyi. Specimen of genus Laurencia are found mainly in tropical, subtropical, and temperate coastal waters ${ }^{98}$ and belong to phylum Rhodophyta, order Ceramiles and Family Rhodomelaceae (see Table 3.1 for the complete classification). ${ }^{99}$

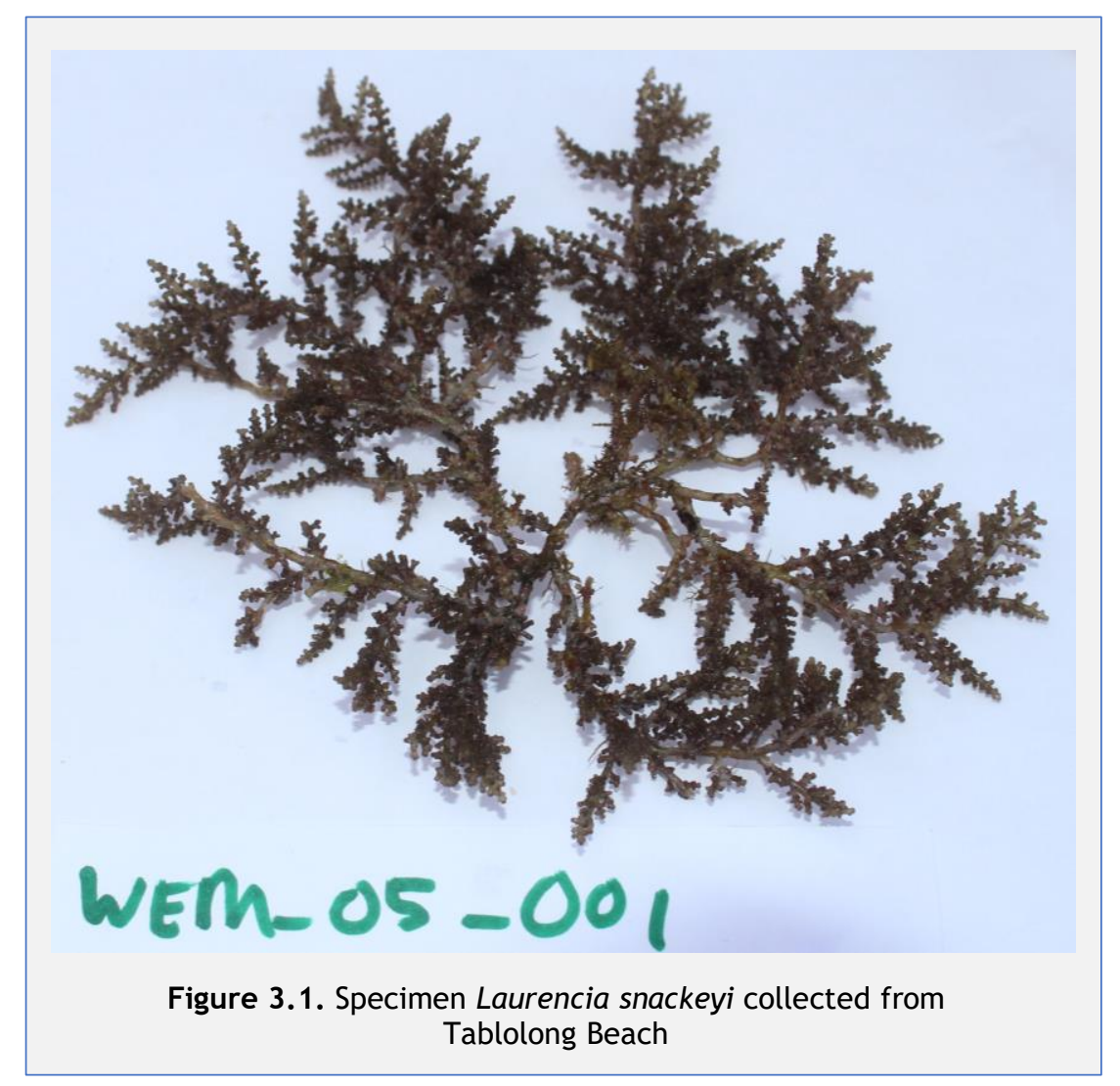

According to Algaebase, this species was first found in Semau Island, Indonesia, during the expedition by Weber-van Bosse in 1923 (the island next to where WEM_05_001 was collected from). ${ }^{99-101}$ L. snackeyi is also found in various locations such as New Caledonia, eastern Australia, Palau Island, Micronesia, the Philippines, Malaysia and Vietnam. ${ }^{101}$ This species grows on the fringing reefs, limestone and dead corals. ${ }^{101}$ 
Table 3.1. Taxonomic classification of Laurencia snackeyi

\author{
Empire: Eukaryota \\ Kingdom: Plantae \\ Subkingdom: Biliphyta \\ Phylum: Rhodophyta \\ Subphylum: Eurhodophytina \\ Class: Florideophyceae \\ Subclass: Rhodymeniophycidae \\ Order: Ceramiales \\ Family: Rhodomelaceae \\ Tribe: Laurencieae \\ Genus: Laurencia \\ Species: snackeyi
}

\title{
3.2. Chemical investigations of Laurencia species
}

Genus Laurencia has been the source of 1,076 reported compounds worldwide (Marinlit MNPs database, accessed November 2018), which are mainly in sesquiterpenes, diterpenes, triterpenes, and C15-acetogenins. ${ }^{98,} 102$ Regarding $L$. snackeyi specifically, a number of halogenated and non-halogenated sesquiterpene secondary metabolites have been reported so far. ${ }^{103-105}$ Most of the reported metabolites came from South East Asia. For example, palisadin A (45), aplysistatin (46), 5-acetoxypalisadin B (47), and palisol (48) were isolated from L. snackeyi which was collected from Kota Kinabalu, Sabah, Malaysia. Aplysistatin (46) inhibited nitric oxide (NO) and prostaglandin-E2 (PGE2) release which may suggest it's use as an anti-inflammatory agent. ${ }^{103} \mathrm{~A}$ few other metabolites such as 5B-hydroxypalisadin B (49), palisadin B (50), palisol (48), and pacifigorgiol (51) also came from L. snackeyi collected from Malaysia. 5B-Hydroxypalisadin B (49) significantly suppressed PGE2 production and reduced nitric oxide synthase (iNOS) and cyclooxygenase-2 (COX-2) expression in Lipopolysaccharide (LPS)-stimulated RAW 264.7 cells. ${ }^{104}$ This anti-inflammatory effect was tested further in a zebrafish (Danio rerio) embryo in vivo model and the results were comparable to the wellknown anti-inflammatory agent dexamethasone. ${ }^{106}$ Meanwhile, other research done in Malaysia and Vietnam resulted in the isolation of a few non-halogenated sesquiterpenes, i.e., snakeol (52), snakediol (53); and nine known sesquiterpenes 
such as: $(R, Z)$-33-dimethyl-5-methylene-4-(3-methylpenta-24-dien-1-yl)cyclohex1-ene (54), palisol (48), pacifigorgiol (55), palisadin D (56), palisadin A (45), palisadin B (50), 5-acetoxypalisadin B (57), debromolaurinterol (58) and abromocuparane (59). ${ }^{101}$ Snakeol (52) and snakediol (52) showed strong antibacterial activity against two human clinical bacterial pathogens, Salmonella typhi and Escherichia coli.

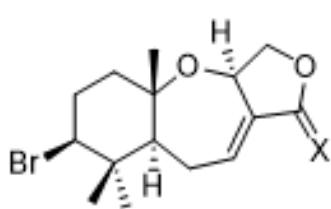

$45 \mathrm{X}=\mathrm{H}$ $46 \times=0$

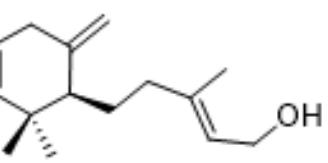

52

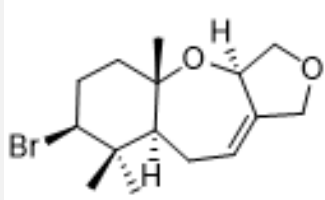

56<smiles>[R]C1C=C(C)[C@@H](CBr)O[C@]2(C)CC[C@@H](Br)C(C)(C)[C@H]12</smiles>

$47 \mathrm{R}=\mathrm{OAC}$ $49 \mathrm{R}=\mathrm{OH}$ $50 \mathrm{R}=\mathrm{H}$

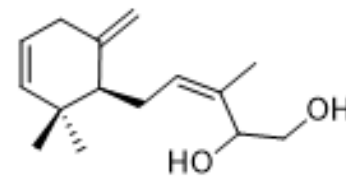

53

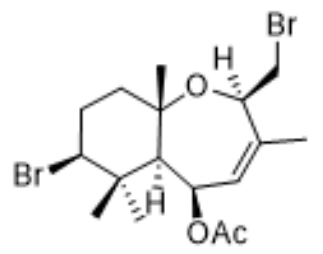

57<smiles>C=C1CC=CC(C)(C)C1C/C=C(/C)[C@H](O)CBr</smiles>

48

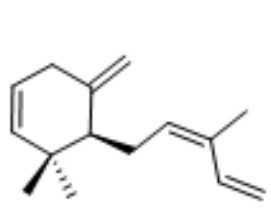

54

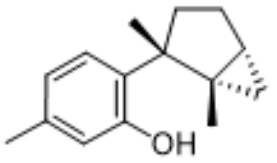

58

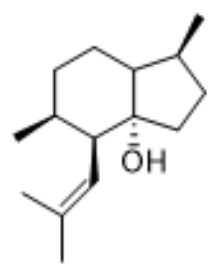

51

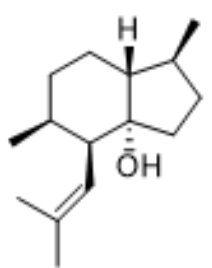

55

Figure 3.2. Previous secondary metabolites extracted from Laurencia snackeyi

\subsection{Isolation and purification procedure}

Specimen of WEM_05_001 was collected from Tablolong Beach, West Timor, Indonesia, in October 2017. The sample was dried under the sun and the thallus of the alga was cut into smaller portion before being subjected to extraction. Dried WEM_05_001 (1.27 g) was extracted with $\mathrm{MeOH}$ twice at the Laboratory of Integrated Science Research of Universitas Nusa Cendana in Kupang, West Timor, Indonesia. The crude extract was then dried under vacuum before being sent to Victoria University of Wellington, New Zealand, for screening and an isolation/purification process. 
The extracts were resuspended in $\mathrm{MeOH}$ that was cyclic-loaded onto PSDVB then eluted with $30 \% \mathrm{Me}_{2} \mathrm{CO} / \mathrm{H}_{2} \mathrm{O}, 75 \% \mathrm{Me}_{2} \mathrm{CO} / \mathrm{H}_{2} \mathrm{O}$ and $\mathrm{Me}_{2} \mathrm{CO}$. The $75 \% \mathrm{Me}{ }_{2} \mathrm{CO} / \mathrm{H}_{2} \mathrm{O}$ $(13.7 \mathrm{mg})$ fraction contained interesting oxymethine peaks (3-5 ppm), detected by ${ }^{1} \mathrm{H}$ NMR spectroscopy. Further purification involved normal phase chromatography using a DIOL column with stepwise elution from hexane, through EtOAc to $\mathrm{MeOH}$ and collected in test tubes which yielded $4.9 \mathrm{mg}$ in fraction 14 . Further purification using $C_{18} \mathrm{HPLC}$ led to the isolation of aminoglyceroglycolipid (60) $(1.0 \mathrm{mg})$ (Scheme 3.1).

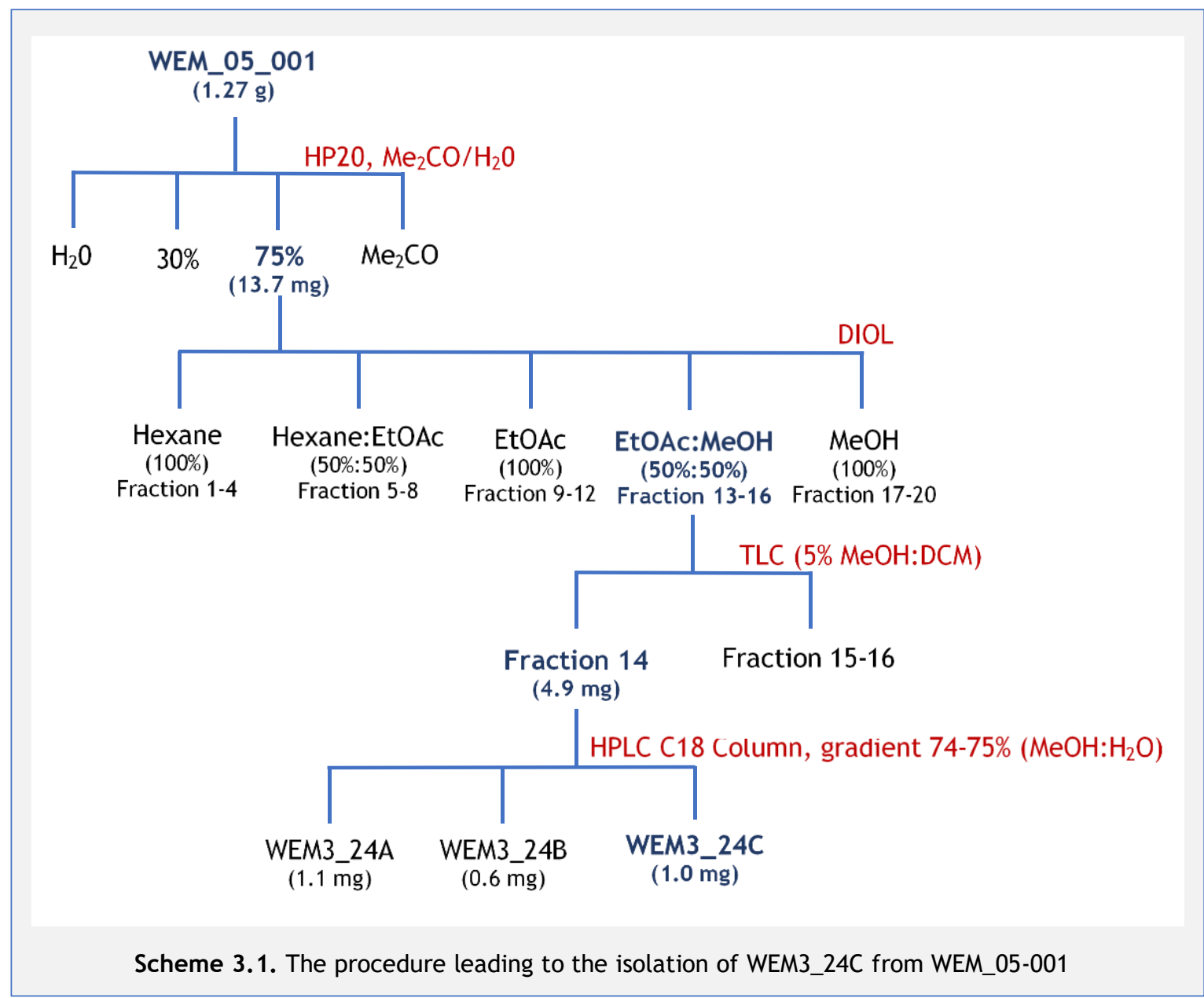




\subsection{Structure elucidation of aminoglyceroglycolipid - WEM3_24C}

Detailed NMR analysis identified two substructures. Analysis of the 1D NMR spectra of WEM3_24C $\left(600 \mathrm{MHz}, \mathrm{CD}_{3} \mathrm{OD}\right)$ showed the presence of resonances attributable to a number of oxymethine protons $\left(\delta_{C} 67-75 ; \delta_{H} 3-5\right)$. These resonances consisted of one acetal $\left(\mathrm{CH}-1 \delta_{\mathrm{C}} 100.1, \delta_{\mathrm{H}} 4.76\right)$, four oxymethines $\left(\mathrm{CH}-2 \delta_{\mathrm{C}} 73.5, \delta_{\mathrm{H}} 3.40\right.$; $\left.\mathrm{CH}-3 \delta_{\mathrm{C}} 74.9, \delta_{\mathrm{H}} 3.63 ; \mathrm{CH}-4 \delta_{\mathrm{C}} 75.1, \delta_{\mathrm{H}} 3.09 ; \mathrm{CH}-5 \delta_{\mathrm{C}} 69.9, \delta_{\mathrm{H}} 4.07\right)$ and one deshielded methylene $\left(\mathrm{CH}_{2}-6 \delta_{C} 54.3, \delta_{H} 3.36,2.92\right)$.

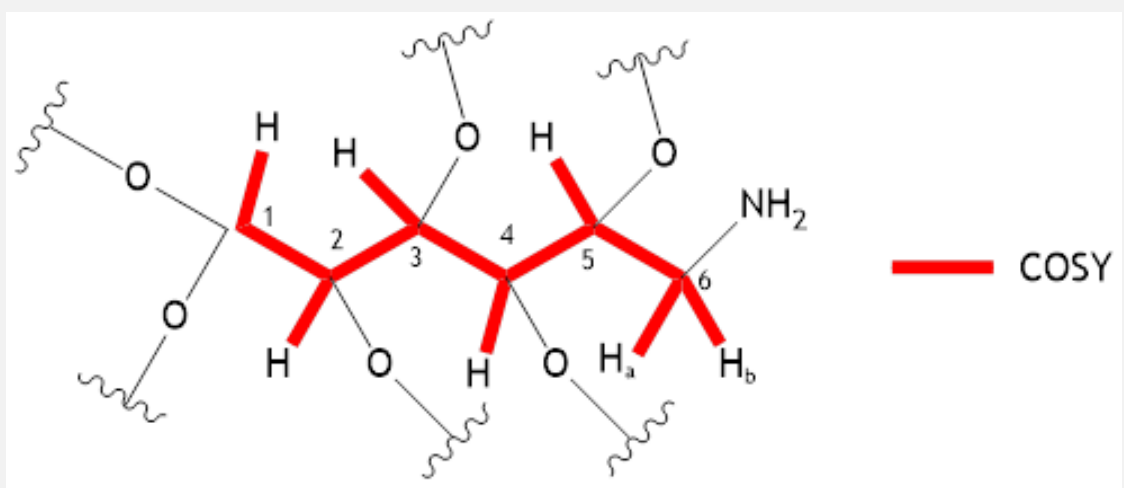

Figure 3.3. COSY correlations establishing a carbon chain consistent with a sugar moiety

Furthermore, a contiguous carbon chain typical of a sugar moiety was revealed from a series of vicinal correlation spectroscopy (COSY) correlations (couplings $\mathrm{H}$ -

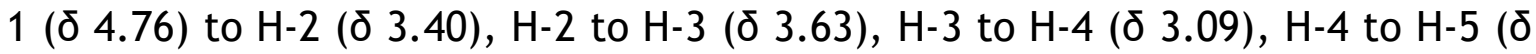
4.07), $\mathrm{H}-5$ to $\mathrm{H}-6_{\mathrm{a}}(\delta 2.92)$ and to $\mathrm{H}-6_{\mathrm{b}}(\delta 3.36)$; and a geminal between $\mathrm{H}-6_{\mathrm{a}}$ and $\left.\mathrm{H}-\mathrm{G}_{\mathrm{b}}\right)$. However, the more shielded chemical shift of $\mathrm{C}-6$ was not consistent with a common carbohydrate, which indicates the presence of an amino functionality (Figure 3.3). There were no further correlations with $\mathrm{H}-6$ suggesting the absence of amide functionality at this carbon position.

A second spin system was revealed from the 2D NMR spectra that contained two oxymethylenes $\left(\mathrm{CH} 2-3{ }^{\prime} \delta_{\mathrm{C}} 67.1, \delta_{\mathrm{H}} 4.11,3.57 ; \mathrm{CH}^{2}-1\right.$ ' $\left.\delta_{\mathrm{C}} 64.3, \delta_{\mathrm{H}} 4.18,4.50\right)$ and an oxymethine $\mathrm{CH}^{\prime} 2^{\prime}\left(\delta_{\mathrm{C}} 71.7, \delta_{\mathrm{H}}\right.$ 5.31). COSY correlations showed vicinal couplings from $\mathrm{H}-1$ ' $\mathrm{a}, \mathrm{b}$ to oxymethine $\mathrm{H}-\mathrm{2}^{\prime}$ and from $\mathrm{H}-2$ ' to $\mathrm{H}-3$ 'a,b. Geminal couplings between $\mathrm{H}-1$ 'a $\left(\delta_{H} 4.18\right)$ to $\mathrm{H}-1$ ' $\mathrm{b}\left(\delta_{\mathrm{H}} 4.50\right)$ and also $\mathrm{H}-3^{\prime}$ 'a $\left(\delta_{\mathrm{H}} 4.11\right)$ to $\mathrm{H}-3^{\prime} \mathrm{b}\left(\delta_{\mathrm{H}} 3.57\right)$ were also observed (Figure 3.4). No further COSY correlations were observed which indicated that C-1', C-2', and C-3' made up a glycerol subunit. The HMBC experiment revealed correlations from $\mathrm{H}-3$ ' $a$, $b$ to $\mathrm{C}-1$ ', and between 
$\mathrm{H}-3$ 'b and $\mathrm{H}-1$ 'a to $\mathrm{C} 2$ further strengthening this assignment. Additionally, an HMBC correlation between $\mathrm{H}-1$ 'a to $\mathrm{C}-1$ " $\left(\delta_{C}\right.$ 175.1) indicated attachment of an ester unit to the glycerol.

Furthermore, next to the glycerol unit, a lipid chain was also established through the COSY experiment, with connections between the methylene protons $(\mathrm{H}-2)\left(\delta_{\mathrm{H}}\right.$ 2.31) to $H-3$ " $\left.\left(\delta_{H} 1.60\right)\right)$ and from $H-3$ " to a large methylene envelope $\left(\delta_{H} 1.29\right)$. The methylene envelope then showed further COSY correlations to methyl CH3-7" $\left(\delta_{H}\right.$ 0.90). Based on the integration values, the lipid chain was estimated as containing 14 methylene units in total, making it a 20 -fatty acid. A Heteronuclear Multiple Bond Correlation ( $\mathrm{HMBC}$ ) correlation from methylene $\mathrm{H} 2-2$ " to ester glycerol C-1" connected the lipid chain and glycerol unit.

Finally, another HMBC experiment connected the glycerol unit ( $\left.\mathrm{H}-3^{\prime} \mathrm{a}, \mathrm{b}\right)$ to $\mathrm{C}-1$ of the sugar moiety, which combined the two structures together (Figure 3.4). The summation of the NMR data indicated that the compound purified was an aminoglycero-glycolipid (Figure 3.4).

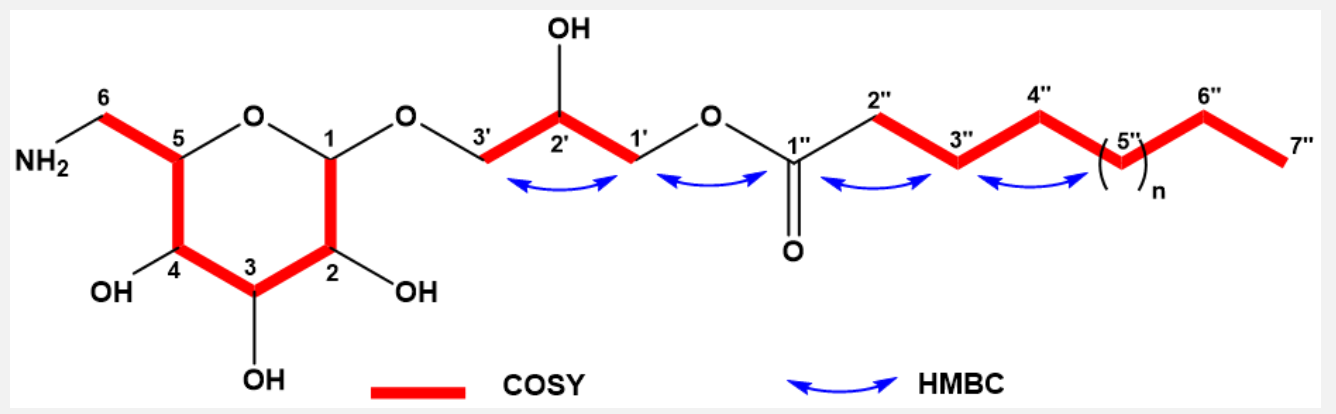

Figure 3.4. COSY and HMBC correlations establishing a connection between a sugar moiety, a glycerol, and lipid unit

The next step was to establish the relative configuration of the carbohydrate system by utilising the coupling constants of the protons around the sugar moiety. As pointed out by Angyal, ${ }^{107}$ a large coupling constant $(\sim 9 \mathrm{~Hz})$ is found in an axial to axial proton relationship, whereas smaller coupling constants are found in the axial to equatorial or equatorial to equatorial proton relationship (both $\sim 3.5 \mathrm{~Hz}$ ). Starting with the anomeric proton, $\mathrm{H}-1$ was observed as a doublet with a coupling constant of $3.8 \mathrm{~Hz}$, which indicated an equatorial-axial relationship with proton $\mathrm{H}-2$. Proton $\mathrm{H}-2$ was shown as a doublet of doublets $(\mathrm{J}=9.7$ and $3.8 \mathrm{~Hz})$, indicative of a 1,2-trans diaxial relationship between $\mathrm{H}-2$ and $\mathrm{H}-3$ (large coupling constant). 
This was followed by $\mathrm{H}-3$ which has an apparent triplet multiplicity and a large coupling constant $(9.3 \mathrm{~Hz})$. These three interactions in the ring system close to the anomeric position, proved that anomeric proton $\mathrm{H}-1$ must be equatorial given the smaller coupling constant (Figure 3.5). A 1,2-trans diaxial vicinal coupling was also found in the interaction of $\mathrm{H}-3$ to $\mathrm{H}-4$ (triplet) with a $9.8 \mathrm{~Hz}$ coupling constant, as well as $\mathrm{H}-4$ to $\mathrm{H}-5$. H-5 presented as a doublet of doublets (dd) instead of a doublet of doublet of doublets (ddd), being a doublet to $\mathrm{H}-4$ and doublets to each $\mathrm{H}-6 \mathrm{a}$ and $\mathrm{H}-6 \mathrm{~b}$ ). As it is a dd, where one of its coupling constants was larger than $\sim 9 \mathrm{~Hz}(9.6$ and $2.2 \mathrm{~Hz})$, one coupling must be close to $0 \mathrm{~Hz}$ indicating an approximate $90^{\circ}$ dihedral angle between $\mathrm{H}-5$ and $\mathrm{H}-6 \mathrm{~b}$. This established the sugar as 6-deoxy-6-amino-glucose and in addition indicated an $\alpha$-link to the glycerol unit.

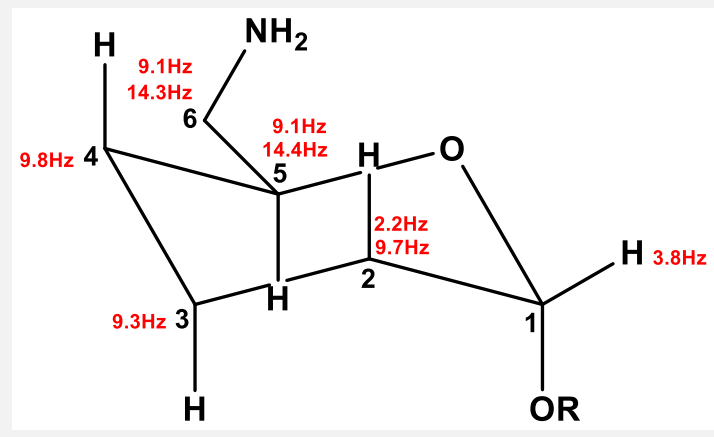

Figure 3.5. Coupling constants determination of the relative amino-sugar moiety

Also, the glycerol linkage was supported using a 2D ROESY (rotating-frame overhauser effect spectroscopy) experiment, confirming the connection between the glucose moiety and the glycerol unit (Figure 3.6).

Unfortunately, due to inconclusive mass spectrometry data, we could not able to find any ions using ESI, APCI OR MALDI-MS ion sources that was consistent with the NMR data. In this case, the length of the lipid chain could not be confirmed exactly by MS or detected in the GNPS molecular network. Unfortunately, due to time constraints, the absolute configuration of the sugar and the biological activity of the compound could not be determined. 
Table 3.2. Tabulated NMR of WEM3_24C for 6-deoxy-6-aminoglycoglyrecolipid (60)

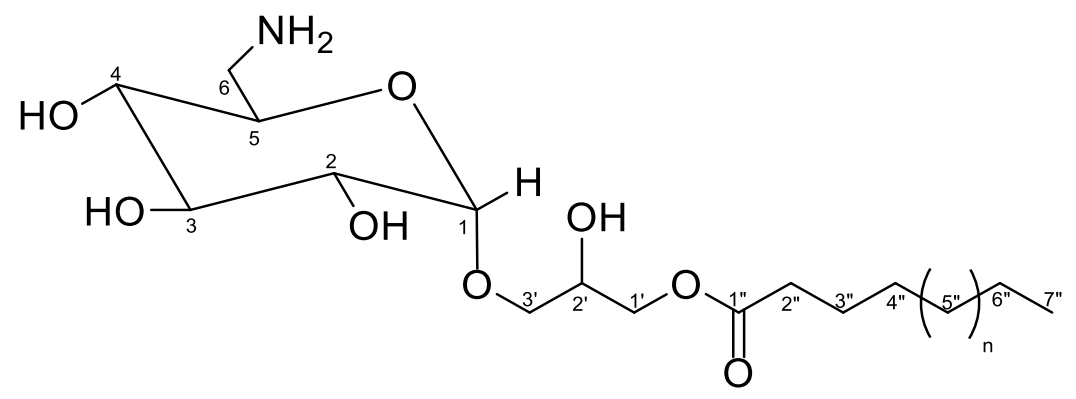

60

\begin{tabular}{|c|c|c|c|c|c|c|c|}
\hline \multirow[b]{2}{*}{ Position } & \multicolumn{2}{|c|}{${ }^{13} \mathrm{C}$} & \multicolumn{3}{|c|}{${ }^{1} \mathrm{H}$} & \multirow[b]{2}{*}{ COSY } & \multirow{2}{*}{$\begin{array}{c}\mathrm{HMBC} \\
\left({ }^{1} \mathrm{H} \text { to }{ }^{13} \mathrm{C}\right)\end{array}$} \\
\hline & $\delta(\mathrm{ppm})$ & $\begin{array}{l}\text { HSQC } \\
\text { (mult) }\end{array}$ & $\begin{array}{c}\delta \\
(\mathrm{ppm})\end{array}$ & mult & $\mathrm{J}(\mathrm{Hz})$ & & \\
\hline 1 & 100.1 & $\mathrm{CH}$ & 4.76 & $d$ & 3.8 & 2 & 3'a, 3’b \\
\hline 2 & 73.5 & $\mathrm{CH}$ & 3.40 & $\mathrm{dd}$ & $3.8,9.7$ & 1 & - \\
\hline 3 & 74.9 & $\mathrm{CH}$ & 3.63 & $\mathrm{t}$ & 9.3 & 4,2 & 1 \\
\hline 4 & 75 & $\mathrm{CH}$ & 3.09 & $\mathrm{t}$ & 9.8 & 3 & - \\
\hline 5 & 69.9 & $\mathrm{CH}$ & 4.07 & $\mathrm{dd}$ & $2.1,9.6$ & $6 a, 6 b, 4$ & 1 \\
\hline $6 a$ & 54.3 & $\mathrm{CH}_{2}$ & 2.92 & dd & $9.1,14.3$ & 5 & - \\
\hline $6 b$ & - & - & 3.36 & dd & $2.2,14.4$ & 5 & - \\
\hline 1 'a & 64.3 & $\mathrm{CH}_{2}$ & 4.18 & $\mathrm{dd}$ & $6.9,12.0$ & 1'b, 2' & 3'a, 3’b \\
\hline $1 ' b$ & - & - & 4.50 & - & - & 1'a, 2' & - \\
\hline $2^{\prime}$ & 71.7 & $\mathrm{CH}$ & 5.31 & $\mathrm{dd}$ & $2.7,5.9$ & $\begin{array}{c}\text { 1'a, 1'b } \\
\text { 3'a }\end{array}$ & 1'a, 3’b \\
\hline 3’a & 67.1 & $\mathrm{CH}_{2}$ & 4.11 & $\mathrm{dd}$ & $5.2,10.9$ & 2', 3’a & - \\
\hline 3’b & - & - & 3.57 & - & - & 2', 3’b & - \\
\hline $1 "$ & 175.1 & C & - & - & - & - & 1 'a \\
\hline $2 "$ & 35.2 & $\mathrm{CH}_{2}$ & 2.31 & $\mathrm{~s}$ & - & $3 "$ & $3 "$ \\
\hline $3 "$ & 26 & $\mathrm{CH}_{2}$ & 1.60 & $d$ & 3.77 & 2", 4" & $2 "$ \\
\hline $4 "$ & 30.8 & $\mathrm{CH}_{2}$ & 1.29 & $\mathrm{~s}$ & - & 7" & $5 "$ \\
\hline $5 "$ & 33.1 & $\mathrm{CH}_{2}$ & 1.29 & $\mathrm{~s}$ & - & 7" & 7" \\
\hline $6 "$ & 23.8 & $\mathrm{CH}_{2}$ & 1.29 & $\mathrm{~s}$ & - & 7" & 7" \\
\hline 7" & 14.5 & $\mathrm{CH}_{3}$ & 0.90 & $\mathrm{~s}$ & - & 6" & - \\
\hline
\end{tabular}




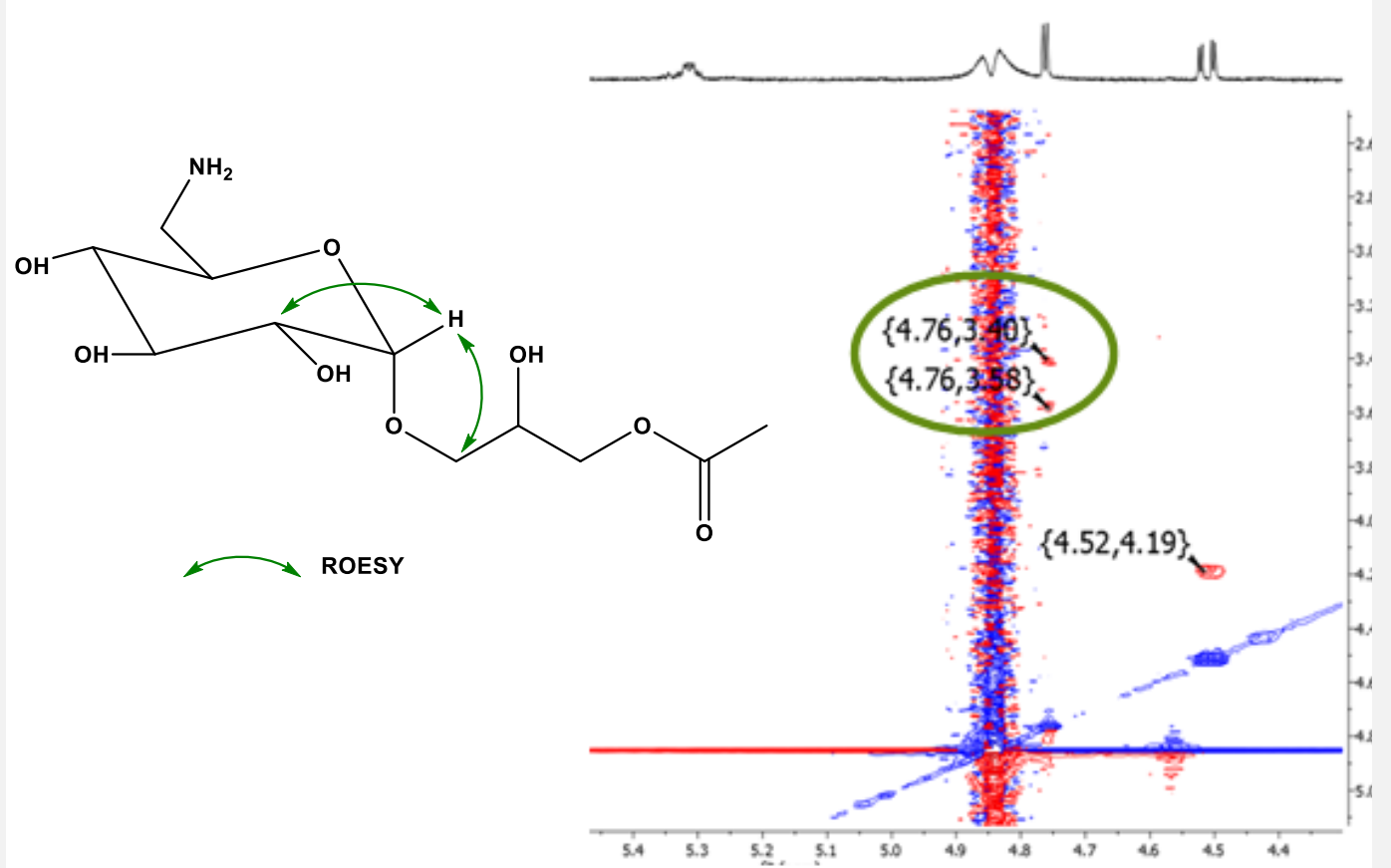

Figure 3.6. ROESY correlations establishing connection between the sugar moiety and glycerol functionality

\subsection{Deoxyaminoglycoglycerolipids}

Glycolipids are carbohydrate-based lipids, which mainly store energy for the producing organism but may also play various biological roles, such as antiinflammatory, anti-tumour, and anti-viral activities. ${ }^{108}$ They are mostly found in higher plants, marine algae, and cyanobacteria. ${ }^{109}$ Based on the a glycosidic fragment linked to a lipidic molecule, there are three main groups of glycoconjugates such as glycosphingolipids, glycoglycerolipids, and atypical glycolipids. ${ }^{110}$ (See Barnathan and coworkers who had reviewed marine invertebrate glycolipids). ${ }^{111}$

6-Deoxy-6-aminoglycoglyrecolipids are glycolipids that have an amine replacing the terminal C- 6 alcohol residue in the carbohydrate moiety; ${ }^{112}$ there are a number of compounds in this category (Figure 3.7). The crude extract of an undescribed algal species led to the isolation of two bioactive aminoglycoglycerolipids $(61,62)$ which showed strong anti-tumour activity against the enzyme Myt1 kinase. ${ }^{113}$ Another aminoglycoglycerolipid avrainvilloside (63) which carries the rare 6deoxy-6-aminoglucose moiety, was obtained from the green alga Avrainvillea 
nigricans collected from the Carribean. ${ }^{114}$ A structurally similar compound, ishigoside (64) was isolated from the methanolic extract of the brown algae Ishige okamurae collected from the coast of Busan, Korea. ${ }^{115}$ Ishigoside has one less methylene chain compared to avrainvilloside, and the researchers claim that ishigoside was a potential free-radical scavenger activity. ${ }^{115}$ Although the number of lipid link could not be determined, 60 appeared to be missing an ester link at C-2' and hence is likely to be new compound and possibly has some kind of similar activity as well. So, future work could be done to isolate or synthesize the compound for testing.

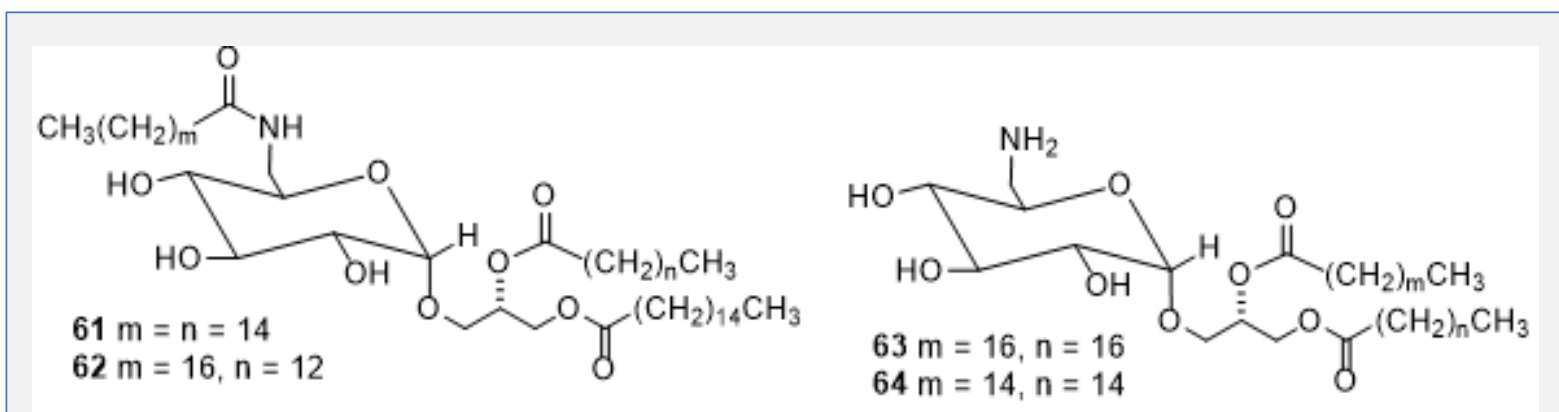

Figure 3.7. Metabolites from deoxyaminoglycoglycerolipids marine algae 


\section{CHAPTER 4. CONCLUDING REMARKS}

Indonesia has a strong macroalgal primary metabolites industry and is the top supplier of phycocolloid sources in the world. Despite the value of these algae, the untapped potential economic importance of the secondary metabolites of Indonesian macroalgae has not been extensively reported. Macroalgae, ecologically sessile organisms, have had to develop non-physical defence mechanisms to survive in the harsh coastal environment, therefore many produce bioactive defensive chemical metabolites.

This study began with the sampling of 40 specimens of tropical Indonesian macroalgae from West Timor waters. A molecular networking screening was employed to prioritise the isolation workflow. The crude extracts of the samples were analysed using liquid chromatography-mass spectrometry (LC-MS)/mass spectrometry (MS) to generate data for creating the molecular network through the Global Natural Product Social Molecular Networking (GNPS) platform. Based on the clusters formed, six samples were prioritised from the molecular network. The suggestions from the screening process were then validated with ${ }^{1} \mathrm{H}$ NMR spectroscopy, which finally prioritised one sample (the other two specimens with interesting ${ }^{1} \mathrm{H}$ NMR spectra did not have enough extracted mass to process further). The structural elucidation of the pure compound isolated highlighted a known 6-deoxy-6-aminoglycoglyrecolipid (60). The presence of the 6-deoxy-6amino motif in the sugar moiety is rare, and literature studies have shown such compounds to have strong anti-tumour activity as well as a potential free-radical scavenger capacity.

Molecular networking through the GNPS platform is rapid and has cut the time to be more efficient in the isolation workflow when compared to bioassays or nuclear magnetic resonance (NMR) screening. However, further optimization can be done to improve the screening procedure. First, optimisation of both LC-MS/MS methods and GNPS settings. This is to maximise the dereplication power through utilisation of the database available from the GNPS website. Secondly, the biomass for extraction should be increased to a minimum $5 \mathrm{~g}$ dry weight of macroalgae to improve the amount of extracted secondary metabolites. 
Finally, the effort to explore marine natural products from tropical Indonesian macroalgae should be continued not only to support the local industry and coastal communities around Indonesia, but also to find novel secondary metabolites for further work. 


\section{CHAPTER 5. EXPERIMENTAL}

All nuclear magnetic resonance (NMR) spectra were obtained using a $600 \mathrm{MHz}$ Varian DirectDrive spectrometer equipped with a cryogenic probe, operating at $600 \mathrm{MHz}$ (for ${ }^{1} \mathrm{H}$ ) and $150 \mathrm{MHz}\left({ }^{13} \mathrm{C}\right.$ nuclei). The residual solvent peak was used as an internal reference for ${ }^{1} \mathrm{H}\left(\delta_{\mathrm{H}} 7.26, \mathrm{CDCl}_{3} ; 3.31, \mathrm{CD}_{3} \mathrm{OD} ; 2.50\right.$, DMSO- $\left.\mathrm{d}_{6}\right)$ and ${ }^{13} \mathrm{C}$ $\left(\delta_{C} 49.00, C_{3} \mathrm{OD}\right)$ chemical shifts. Mass spectrometry $(M S)$ data was collected using an Agilent 6530 quadrupole time-of-flight (QTOF) liquid chromatographymass spectrometry (LC-MS) instrument. High performance liquid chromatography (HPLC) purifications were carried out using a Rainin Dynamax SD-200 solvent delivery system with $25 \mathrm{~mL}$ pump heads. Reversed phase HPLC was carried out with Phenomenex Prodigy octadecyl-derivatised silica gel $\left(C_{18}\right)$ (analytical: $4.6 \times$ $250 \mathrm{~mm}, 5 \mu \mathrm{m}$; semi-preparative: $10 \times 250 \mathrm{~mm}, 5 \mu \mathrm{m}$ ). Semipreparative HPLC was performed at a flowrate of $5 \mathrm{~mL} / \mathrm{min}$. All solvents used for column chromatography were of HPLC grade, and the $\mathrm{H}_{2} \mathrm{O}$ was glass distilled.

Thin layer chromatography (TLC) analysis was performed using Macherey-Nagel plastic Polygram SIL G/UV 254 plates. Developed TLC plates were visualised under a UV lamp source $(\lambda=254 \mathrm{~nm})$, then analysed by dipping in a solution of $5 \% \mathrm{H}_{2} \mathrm{SO}_{4}$ (conc.) $/ \mathrm{MeOH}$, followed by a solution of $0.1 \%$ vanillin/EtOH (\% wt $/ \mathrm{vol}$ ) and heating. The mobile phase used for TLC was $5 \% \mathrm{MeOH} / \mathrm{DCM}$ (dichloromethane). Normal-phase column chromatography was carried out using silica $\left(\mathrm{SiO}_{2}\right)$ gels. Reversed-phase column chromatography was achieved using Supelco Dianion PSDVB HP20 chromatographic resin.

\subsection{Sampling location}

The research was carried out in Timor Island and Semau Island coastal waters, East Nusa Tenggara Province, Indonesia. Four locations were visited to collect fresh samples of macroalgae (see Figure 2.5). Three of the sites are in Timor Island i.e., Sulamu Beach (10 $3^{\circ} 5.463^{\prime \prime} S$ and $123^{\circ} 36^{\prime} 52.29^{\prime \prime}$ E), Pasir Panjang Beach

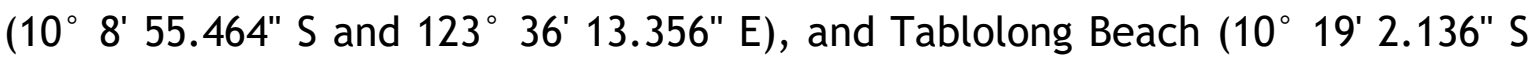
and $\left.123^{\circ} 28^{\prime} 13.728^{\prime \prime} E\right)$. While another collection site, Akle Beach, is on Semau Island (10 $10^{\circ} 20.7048^{\prime \prime} \mathrm{S}$ and $123^{\circ} 20^{\prime} 12.444^{\prime \prime} \mathrm{E}$ ). Sampling of the fresh macroalgae was done in the intertidal area during the low tide period. Samples were collected in water no deeper than knee height. A total of 40 samples of different species of 
brown, red, and green macroalgae were collected from all four sites (Appendix B).

\subsection{Deoxyribonucleic acid barcoding}

Deoxyribonucleic acid (DNA) barcoding began with extraction of dry tissue from alga (stored in silica gel) using a modified Cetyl trimethylammonium bromide (CTAB) buffer procedure. ${ }^{116}$ A 615 bp fragment from the $5^{\prime}$ end of the mitochondrial marker cytochrome oxidase subunit I (cox1) gene was amplified using primer pairs GazF1 and GazR1 (GazF1 5' TCAACAAATCATAAAGATATTGG 3' and GazR1 5' ACTTCTGGATGTCCAAAAAAYCA 3'). ${ }^{117}$ The Polymerase chain reaction (PCR) products were cleaned with ExoSAP-IT (USB, Cleveland, Ohio) enzymes and sequenced commercially (Macrogen Inc., Seoul, Korea).

\subsection{Sample extraction}

Prior to extraction, samples were dried under the sun for two to three days, labelled and stored. The extraction was done in the Integrated Science Laboratory of Universitas Nusa Cendana, Kupang, Indonesia. The samples were macerated and extracted twice in methanol for 24-hour periods. Both extracts were then combined. The methanol extract was subsequently concentrated in vacuo to dry samples completely or remove the methanol. As the last step, the remaining solution (presumably water) was removed in a freeze dryer at $-100 \mathrm{oC}$ to $-1210 \mathrm{C}$. The dried samples were finally obtained and sent to Victoria University of Wellington for further analysis (see Appendix B).

\subsection{Global natural product social molecular networking}

The crude extracts were diluted in $30 \mathrm{~mL} \mathrm{MeOH}$ and subsampled for untargeted LC-MS/MS $\left(0.1 \mathrm{mg} \mathrm{mL}^{-1}\right)$ to get data for Global Natural Product Social Molecular Networking (GNPS) molecular molecular networking. A molecular network was created using the online workflow at GNPS. The data were filtered by removing all MS/MS peaks within +/- $17 \mathrm{Da}$ of the precursor $\mathrm{m} / \mathrm{z}$. MS/MS spectra were window filtered by choosing only the top 6 peaks in the +/-50Da window throughout the spectrum. The data was then clustered using MS-Cluster with a parent mass tolerance of $0.02 \mathrm{Da}$ and a MS/MS fragment ion tolerance of $0.02 \mathrm{Da}$ to create consensus spectra. Further, consensus spectra that contained less than 2 spectra were discarded. A network was then created where edges were filtered to have a cosine score above 0.7 and more than 6 matched peaks. Further edges 
between two nodes were kept in the network if and only if each of the nodes appeared in each other's respective top 10 most similar nodes. The spectra in the network were then searched against the GNPS spectral libraries. The library spectra were filtered in the same manner as the input data. All matches kept between network spectra and library spectra were required to have a score above 0.7 and at least 6 matched peaks.

\subsection{Isolation of compound from Laurencia snackeyi}

The crude extract was diluted in $30 \mathrm{~mL} \mathrm{MeOH}$ passing through a $20 \mathrm{~mL}$ column of HP20 beads (see Scheme 3.1). The resulting eluent was diluted with $30 \mathrm{~mL}$ of distilled $\mathrm{H}_{2} \mathrm{O}\left(50 \% \mathrm{MeOH}\right.$ in $\mathrm{H}_{2} \mathrm{O}$ solution) and passed back through the HP2O column. The eluent was diluted again with $60 \mathrm{~mL}$ of distilled $\mathrm{H}_{2} \mathrm{O}(25 \% \mathrm{MeOH}$ in $\mathrm{H}_{2} \mathrm{O}$ solution) and the resulting $120 \mathrm{~mL}$ eluent passed back through the column. Lastly, the eluent was diluted again with $120 \mathrm{~mL} \mathrm{H} \mathrm{H}_{2} \mathrm{O}(12.5 \% \mathrm{MeOH}$ solution) then passed back through the column. The column was washed with $60 \mathrm{~mL}$ portions of 1) $\mathrm{H}_{2} \mathrm{O}$, 2) $\left.30 \% \mathrm{Me}_{2} \mathrm{CO} / \mathrm{H}_{2} \mathrm{O}, 3\right) 75 \% \mathrm{Me}_{2} \mathrm{CO} / \mathrm{H}_{2} \mathrm{O}$, and 4) $100 \% \mathrm{Me}_{2} \mathrm{CO}$. The $100 \%$ $\mathrm{Me}_{2} \mathrm{CO}$ fraction was concentrated to dryness under reduced pressure to provide $9.9 \mathrm{mg}$ of material, while the $30 \%$ and $75 \% \mathrm{Me}_{2} \mathrm{CO} / \mathrm{H}_{2} \mathrm{O}$ fractions were each backloaded onto $20 \mathrm{~mL}$ of individual HP20 resin columns in order to remove the water. Each column was then eluted with $\mathrm{Me}_{2} \mathrm{CO}$ to give $0.9 \mathrm{mg}$ of the $30 \%$ fraction and $13.7 \mathrm{mg}$ of the $75 \%$ fraction.

The $75 \%$ fraction was purified further using a $10 \mathrm{~mL}$ normal-phase diol column then eluted with a series of solvents, $30 \mathrm{~mL}$ each, which were collected in test tubes. The solvents were 100\% Hexane (fractions 1-4), 50\% Hexane/EtOAc (fractions 58), 100\% EtOAc (fractions 9-12), 50\% EtOAc/MeOH (fractions 13-16), and 100\% $\mathrm{MeOH}$ (fractions 17-20). All fractions were dried under reduced pressure before TLC analysis was used to combined fractions. Fraction 14 (from 50\% EtOAc/MeOH elution) was chromatographed on a semi-preparative $C_{18}$ reversed-phase HPLC column, with a gradient $74-75 \% \mathrm{MeOH}$ in $\mathrm{H}_{2} \mathrm{O}$ as the mobile phase, at a flow rate of $5 \mathrm{~mL} / \mathrm{min}$. The compound of interest was the third fraction collected and had a retention time of approximately $1320 \mathrm{~s}$. No further purification was observed with a mass of $1.0 \mathrm{mg}$ recovered (WEM3_24C) which was a 6-deoxy-6aminoglycoglyrecolipid (60). 


\section{BIBLIOGRAPHY}

1. Dias, D. A.; Urban, S.; Roessner, U., A Historical Overview of Natural Products in Drug Discovery. Metabolites 2012, 2 (2), 303-336.

2. Cragg, G. M.; Newman, D. J., Natural products: a continuing source of novel drug leads. Biochimica et biophysica acta 2013, 1830 (6), 3670-3695.

3. Heo, S.; Hwang, J.; Choi, J.; Han, J.; Kim, H.; Jeon, Y., Diphlorethohydroxycarmalol isolated from Ishige okamurae, a brown algae a potent postprandial hyperglycemia in diabetic mice. European Journal of Pharmacology 2009, 615, 252-256.

4. Joshi, V., Some plants used in ayurvedic and homoeopathic medicine. Journal of Pharmacognosy and Phytochemistry 2013, 2 (1).

5. Dev, S., Ancient-modern concordance in Ayurvedic plants: some examples. Environmental Health Perspectives 1999, 107 (10), 783-789.

6. Yadav, V.; Jayalakshmi, S.; Singla, R. K., Traditional systems of medicineNow \& Forever. 2012.

7. Beutler, J.; DerMarderosian, A., The review of natural products. 2004.

8. Faurant, C., From bark to weed: The history of artemisinin. Parasite 2011, 18 (3), 215-218.

9. Wani, M. C.; Taylor, H. L.; Wall, M. E.; Coggon, P.; McPhail, A. T., Plant antitumor agents. VI. Isolation and structure of taxol, a novel antileukemic and antitumor agent from Taxus brevifolia. Journal of the American Chemical Society 1971, 93 (9), 2325-2327.

10. Newman, D. J.; Cragg, G. M., Natural products as sources of new drugs over the 30 years from 1981 to 2010. Journal of natural products 2012, 75 (3), 311.

11. Bowling, J. J.; Kochanowska, A. J.; Kasanah, N.; Hamann, M. T., Nature's bounty-drug discovery from the sea. Expert opinion on drug discovery 2007, 2 (11), 1505-1522.

12. Yuan, H.; Ma, Q.; Ye, L.; Piao, G., The traditional medicine and modern medicine from natural products. Molecules 2016, 21 (5), 559.

13. Carter, G. T., Natural products and Pharma 2011: Strategic changes spur new opportunities. Natural Product Reports 2011, 28 (11), 1783-1789.

14. Molinski, T. F.; Dalisay, D. S.; Lievens, S. L.; Saludes, J. P., Drug development from marine natural products. Nature Reviews Drug Discovery 2009, 8 (1), 69-85.

15. Faulkner, D. J., Marine natural products: metabolites of marine algae and herbivorous marine molluscs. Natural Product Reports 1984, 1 (3), 251-280.

16. Blunt, J. W.; Copp, B. R.; Keyzers, R. A.; Munro, M. H. G.; Prinsep, M. R., Marine natural products. Natural Product Reports 2017, 34 (3), 235-294. 
17. Bergmann, W.; BURKE, D. C., Contributions to the study of marine products. XXXIX. The nucleosides of sponges. III. 1 Spongothymidine and spongouridine2. The Journal of Organic Chemistry 1955, 20 (11), 1501-1507.

18. Bergmann, W.; Feeney, R. J., Contributions to the study of marine products. XXXII. The nucleosides of sponges. I. 1. The Journal of Organic Chemistry 1951, 16 (6), 981-987.

19. Suckling, C. J., Chemical approaches to the discovery of new drugs. Science Progress (1933-) 1991, 323-359.

20. Newman, D. J.; Cragg, G. M., Marine natural products and related compounds in clinical and advanced preclinical trials. Journal of natural products 2004, 67 (8), 1216-1238.

21. Montaser, R.; Luesch, H., Marine natural products: a new wave of drugs? Future 2011, 3 (12), 1475-1489.

22. McGivern, J. G., Ziconotide: a review of its pharmacology and use in the treatment of pain. Neuropsychiatric disease and treatment 2007, 3 (1), 69.

23. Olivera, B. M., $\omega$-Conotoxin MVIIA: from marine snail venom to analgesic drug. In Drugs from the Sea, Karger Publishers: 2000; pp 74-85.

24. Somaiah, N.; von Mehren, M., New drugs and combinations for the treatment of soft-tissue sarcoma: a review. Cancer management and research 2012, 4, 397.

25. Mayer, A. M.; Glaser, K. B.; Cuevas, C.; Jacobs, R. S.; Kem, W.; Little, R. D.; McIntosh, J. M.; Newman, D. J.; Potts, B. C.; Shuster, D. E., The odyssey of marine pharmaceuticals: a current pipeline perspective. Trends in pharmacological sciences 2010, 31 (6), 255-265.

26. Arifin, H. S.; Nakagoshi, N., Landscape ecology and urban biodiversity in tropical Indonesian cities. Landscape and ecological engineering 2011, 7 (1), 33-43.

27. Strid, P., Implementation of Agenda 21: Review on progress made since the United Nations Conference on Environment and Development, 1992. SADC, Subregional Report, United Nations Commission on Sustainable Development. Fifth Session 1997, 7-25.

28. Huffard, C.; Erdmann, M.; Gunawan, T., Geographic priorities for marine biodiversity conservation in Indonesia. Jakarta: Ministry of Marine Affairs and Fisheries and Marine Protected Areas Governance Program 2012.

29. White, A. T.; Aliño, P. M.; Cros, A.; Fatan, N. A.; Green, A. L.; Teoh, S. J.; Laroya, L.; Peterson, N.; Tan, S.; Tighe, S.; Venegas-Li, R.; Walton, A.; Wen, W., Marine Protected Areas in the Coral Triangle: Progress, Issues, and Options. Coastal Management 2014, 42 (2), 87-106.

30. Veron, J.; Devantier, L. M.; Turak, E.; Green, A. L.; Kininmonth, S.; StaffordSmith, M.; Peterson, N., Delineating the coral triangle. Galaxea, Journal of Coral Reef Studies 2009, 11 (2), 91-100. 
31. Tursch, B.; Braekman, J. C.; Daloze, D.; Fritz, P.; Kelecom, A.; Karlsson, R.; Losman, D., Chemical studies of marine invertebrates. VIII africanol, an unusual sesquiterpene from Lemnalia africana (Coelenterata, Octocorallia, Alcyonacea). Tetrahedron Letters 1974, 15 (9), 747-750.

32. Ayanoglu, E.; Gebreyesus, T.; Beechan, C.; Djerassi, C.; Kaisin, M., Terpenoids LXXV. $\Delta 9$ (12)-capnellene, a new sesquiterpene hydrocarbon from the soft coral capnellaimbricata. Tetrahedron Letters 1978, 19 (19), 1671-1674.

33. Sheikh, Y.; Djerassi, C.; Braekman, J. C.; Daloze, D.; Kaisin, M.; Tursch, B.; Karlsson, R., Terpenoids-LXXII. Chemical studies of marine invertebrates. XXVI. Delta-9 (12)-capnellene-3beta, 8beta, 10alpha, 14-tetrol, a novel polyoxygenated sesquiterpene from the Alcyonarian Capnella imbricata. Tetrahedron 1977, 33 (16), 2115-2117.

34. Beechan, C. M.; Djerassi, C.; Eggert, H., Terpenoids-LXXIV. Tetrahedron 1978, 34 (16), 2503-2508.

35. Williams, D. E.; Patrick, B. O.; Tahir, A.; Van Soest, R.; Roberge, M.; Andersen, R. J., Boneratamides A-C, New Sesquiterpenoids Isolated from the Marine Sponge Axinyssa aplysinoides. Journal of Natural Products 2004, 67 (10), 1752-1754.

36. Rashid, M. A.; Gustafson, K. R.; Cartner, L. K.; Shigematsu, N.; Pannell, L. K.; Boyd, M. R., Microspinosamide, a New HIV-Inhibitory Cyclic Depsipeptide from the Marine Sponge Sidonops microspinosa. Journal of Natural Products 2001, 64 (1), 117-121.

37. Peng, J.; Hu, J.-F.; Kazi, A. B.; Li, Z.; Avery, M.; Peraud, O.; Hill, R. T.; Franzblau, S. G.; Zhang, F.; Schinazi, R. F., Manadomanzamines A and B: a novel alkaloid ring system with potent activity against mycobacteria and HIV1. Journal of the American Chemical Society 2003, 125 (44), 13382-13386.

38. Somei, M.; Yamada, F., Simple indole alkaloids and those with a nonrearranged monoterpenoid unit. Natural Product Reports 2005, 22 (1), 73103.

39. Tsukamoto, S.; Kawabata, T.; Kato, H.; Ohta, T.; Rotinsulu, H.; Mangindaan, R. E.; Van Soest, R. W.; Ukai, K.; Kobayashi, H.; Namikoshi, M., Naamidines $\mathrm{H}$ and $\mathrm{I}$, cytotoxic imidazole alkaloids from the Indonesian marine sponge Leucetta chagosensis. Journal of natural products 2007, 70 (10), 1658-1660.

40. Jadulco, R.; Proksch, P.; Wray, V.; Sudarsono; Berg, A.; Gräfe, U., New Macrolides and Furan Carboxylic Acid Derivative from the Sponge-Derived Fungus Cladosporium herbarum. Journal of Natural Products 2001, 64 (4), 527-530.

41. Edrada, R. A.; Heubes, M.; Brauers, G.; Wray, V.; Berg, A.; Gräfe, U.; Wohlfarth, M.; Mühlbacher, J.; Schaumann, K.; Sudarsono; Bringmann, G.; Proksch, P., Online Analysis of Xestodecalactones A-C, Novel Bioactive Metabolites from the Fungus Penicillium cf. montanense and Their Subsequent Isolation from the Sponge Xestospongia exigua. Journal of Natural Products 2002, 65 (11), 1598-1604. 
42. MacArtain, P.; Gill, C. I.; Brooks, M.; Campbell, R.; Rowland, I. R., Nutritional value of edible seaweeds. Nutrition reviews 2007, 65 (12), 535543.

43. Saha, D.; Bhattacharya, S., Hydrocolloids as thickening and gelling agents in food: a critical review. Journal of food science and technology 2010, 47 (6), 587-597.

44. Nisizawa, K.; Noda, H.; Kikuchi, R.; Watanabe, T., The main seaweed foods in Japan. Hydrobiologia 1987, 151 (1), 5-29.

45. Glicksman, M., Utilization of seaweed hydrocolloids in the food industry. Hydrobiologia 1987, 151 (1), 31-47.

46. Hay, M. E., The functional morphology of turf-forming seaweeds: persistence in stressful marine habitats. Ecology 1981, 62 (3), 739-750.

47. Davison, I. R.; Pearson, G. A., Stress tolerance in intertidal seaweeds. Journal of Phycology 1996, 32 (2), 197-211.

48. Stachowicz, J. J., Mutualism, facilitation, and the structure of ecological communities: positive interactions play a critical, but underappreciated, role in ecological communities by reducing physical or biotic stresses in existing habitats and by creating new habitats on which many species depend. AlBS Bulletin 2001, 51 (3), 235-246.

49. Lane, A. L.; Kubanek, J., Secondary metabolite defenses against pathogens and biofoulers. In Algal chemical ecology, Springer: 2008; pp 229-243.

50. Steinberg, P. D.; De Nys, R., Chemical Mediation of Colonization Of Seaweed Surfaces. Journal of Phycology 2002, 38 (4), 621-629.

51. Maschek, J. A.; Baker, B. J., The chemistry of algal secondary metabolism. In Algal chemical ecology, Springer: 2008; pp 1-24.

52. Blunt, J.; Hartshorn, M.; Munro, M.; Yorke, S., A novel, C8 dichlorodienol metabolite of the red alga plocamiumcraciferum. Tetrahedron Letters 1978, 19 (45), 4417-4418.

53. Blunt, J.; Hartshorn, M.; McLennan, T.; Munro, M.; Robinson, W. T.; Yorke, S., Thyrsiferol: a squalene-derived metabolite of laurenciathyrsifera. Tetrahedron Letters 1978, 19 (1), 69-72.

54. Blackman, A.; Wells, R., Flexilin and trifarin, terpene 1, 4-diacetoxybuta-1, 3-dienes from two CAULERPA species (chlorophyta). Tetrahedron Letters 1978, 19 (33), 3063-3064.

55. Culioli, G.; Daoudi, M.; Ortalo-Magné, A.; Valls, R.; Piovetti, L., (S)-12Hydroxygeranylgeraniol-derived diterpenes from the brown alga Bifurcaria bifurcata. Phytochemistry 2001, 57 (4), 529-535.

56. Kasanah, N.; Triyanto, T.; Seto, D. S.; Amelia, W.; Isnansetyo, A., Antibacterial Compounds from Red Seaweeds (Rhodophyta). Indonesian Journal of Chemistry 2015, 15 (2), 201-209.

57. Guiry, M. D. G., G.M AlgaeBase. World-wide electronic publication. http://www.algaebase.org (accessed 28 April 2017). 
58. FAO The State of World Fisheries and Aquaculture 2016: Contributing to food security and nutrition for all; 2016; p 200 pp.

59. Yoo, H.-D.; Ketchum, S. O.; France, D.; Bair, K.; Gerwick, W. H., Vidalenolone, a novel phenolic metabolite from the tropical red alga Vidalia sp. Journal of natural products 2002, 65 (1), 51-53.

60. Sun, Y.; Xu, Y.; Liu, K.; Hua, H.; Zhu, H.; Pei, Y., Gracilarioside and gracilamides from the red alga Gracilaria asiatica. Journal of natural products 2006, 69 (10), 1488-1491.

61. Eloff, J. N., A sensitive and quick microplate method to determine the minimal inhibitory concentration of plant extracts for bacteria. Planta medica 1998, 64 (8), 711-3.

62. Koehn, F. E.; Carter, G. T., The evolving role of natural products in drug discovery. Nature reviews Drug discovery 2005, 4 (3), 206.

63. Hostettmann, K.; Wolfender, J.-L.; Terreaux, C., Modern screening techniques for plant extracts. Pharmaceutical biology 2001, 39 (sup1), 1832.

64. Koehn, F. E., High impact technologies for natural products screening. In Natural Compounds as Drugs Volume I, Springer: 2008; pp 175-210.

65. Ito, T.; Masubuchi, M., Dereplication of microbial extracts and related analytical technologies. The Journal of antibiotics 2014, 67 (5), 353.

66. Moser, A.; Wheeler, P.; Hayward, S., Dereplication of Natural Products by NMR: A Three-Stage Approach ACD/Structure Elucidator Suite and ACD/Labs' Content Databases.

67. Blunt, J. W.; Calder, V. L.; Fenwick, G. D.; Lake, R. J.; McCombs, J. D.; Munro, M. H.; Perry, N. B., Reverse phase flash chromatography: a method for the rapid partitioning of natural product extracts. Journal of natural products 1987, $50(2), 290-292$.

68. Woolner, V. H. New Halogenated SecondaryMetabolites from Red Algae of the South Pacific. Victoria University of Wellington, 2017.

69. Popplewell, W. L. Isolation and Structure Elucidation of New Secondary Metabolites from New Zealand Marine Red Algae. Victoria University of Wellington, 2008.

70. Keyzers, R. A. The isolation of biologically active secondary metabolites from New Zealand marine organisms. Victoria University of Wellington, 2003.

71. Korfmacher, W. A., Foundation review: Principles and applications fo LC-MS in new drug discovery. Drug discovery today 2005, 10 (20), 1357-1367.

72. Bythell, B. J.; Hendrickson, C. L.; Marshall, A. G., Relative Stability of Peptide Sequence Ions Generated by Tandem Mass Spectrometry. Journal of The American Society for Mass Spectrometry 2012, 23 (4), 644-654.

73. Vaiano, F.; Serpelloni, G.; Focardi, M.; Fioravanti, A.; Mari, F.; Bertol, E., LC-MS/MS and GC-MS methods in propofol detection: Evaluation of the two analytical procedures. Forensic science international 2015, 256, 1-6. 
74. Niessen, W., Progress in liquid chromatography-mass spectrometry instrumentation and its impact on high-throughput screening. Journal of chromatography A 2003, 1000 (1), 413-436.

75. Loboda, A., Method and system for operating a time of flight mass spectrometer detection system. Google Patents: 2014.

76. Duncan, K. R.; Crüsemann, M.; Lechner, A.; Sarkar, A.; Li, J.; Ziemert, N.; Wang, M.; Bandeira, N.; Moore, B. S.; Dorrestein, P. C., Molecular networking and pattern-based genome mining improves discovery of biosynthetic gene clusters and their products from Salinispora species. Chemistry \& biology 2015, 22 (4), 460-471.

77. Wang, M.; Carver, J. J.; Phelan, V. V.; Sanchez, L. M.; Garg, N.; Peng, Y.; Nguyen, D. D.; Watrous, J.; Kapono, C. A.; Luzzatto-Knaan, T.; Porto, C.; Bouslimani, A.; Melnik, A. V.; Meehan, M. J.; Liu, W.-T.; Crüsemann, M.; Boudreau, P. D.; Esquenazi, E.; Sandoval-Calderón, M.; Kersten, R. D.; Pace, L. A.; Quinn, R. A.; Duncan, K. R.; Hsu, C.-C.; Floros, D. J.; Gavilan, R. G.; Kleigrewe, K.; Northen, T.; Dutton, R. J.; Parrot, D.; Carlson, E. E.; Aigle, B.; Michelsen, C. F.; Jelsbak, L.; Sohlenkamp, C.; Pevzner, P.; Edlund, A.; McLean, J.; Piel, J.; Murphy, B. T.; Gerwick, L.; Liaw, C.-C.; Yang, Y.-L.; Humpf, H.-U.; Maansson, M.; Keyzers, R. A.; Sims, A. C.; Johnson, A. R.; Sidebottom, A. M.; Sedio, B. E.; Klitgaard, A.; Larson, C. B.; Boya P, C. A.; Torres-Mendoza, D.; Gonzalez, D. J.; Silva, D. B.; Marques, L. M.; Demarque, D. P.; Pociute, E.; O'Neill, E. C.; Briand, E.; Helfrich, E. J. N.; Granatosky, E. A.; Glukhov, E.; Ryffel, F.; Houson, H.; Mohimani, H.; Kharbush, J. J.; Zeng, Y.; Vorholt, J. A.; Kurita, K. L.; Charusanti, P.; McPhail, K. L.; Nielsen, K. F.; Vuong, L.; Elfeki, M.; Traxler, M. F.; Engene, N.; Koyama, N.; Vining, O. B.; Baric, R.; Silva, R. R.; Mascuch, S. J.; Tomasi, S.; Jenkins, S.; Macherla, V.; Hoffman, T.; Agarwal, V.; Williams, P. G.; Dai, J.; Neupane, R.; Gurr, J.; Rodríguez, A. M. C.; Lamsa, A.; Zhang, C.; Dorrestein, K.; Duggan, B. M.; Almaliti, J.; Allard, P.-M.; Phapale, P.; Nothias, L.-F.; Alexandrov, T.; Litaudon, M.; Wolfender, J.-L.; Kyle, J. E.; Metz, T. O.; Peryea, T.; Nguyen, D.-T.; VanLeer, D.; Shinn, P.; Jadhav, A.; Müller, R.; Waters, K. M.; Shi, W.; Liu, X.; Zhang, L.; Knight, R.; Jensen, P. R.; Palsson, B. Ø.; Pogliano, K.; Linington, R. G.; Gutiérrez, M.; Lopes, N. P.; Gerwick, W. H.; Moore, B. S.; Dorrestein, P. C.; Bandeira, N., Sharing and community curation of mass spectrometry data with Global Natural Products Social Molecular Networking. Nature Biotechnology 2016, 34, 828.

78. Watrous, J.; Roach, P.; Alexandrov, T.; Heath, B. S.; Yang, J. Y.; Kersten, R. D.; van der Voort, M.; Pogliano, K.; Gross, H.; Raaijmakers, J. M.; Moore, B. S.; Laskin, J.; Bandeira, N.; Dorrestein, P. C., Mass spectral molecular networking of living microbial colonies. Proceedings of the National Academy of Sciences 2012, 109 (26), E1743-E1752.

79. Morrow, J. K.; Tian, L.; Zhang, S., Molecular networks in drug discovery. Critical Reviews ${ }^{\mathrm{TM}}$ in Biomedical Engineering 2010, 38 (2).

80. Nguyen, D. D.; Wu, C.-H.; Moree, W. J.; Lamsa, A.; Medema, M. H.; Zhao, X.; Gavilan, R. G.; Aparicio, M.; Atencio, L.; Jackson, C., MS/MS networking guided analysis of molecule and gene cluster families. Proceedings of the National Academy of Sciences 2013, 110 (28), E2611-E2620. 
81. Sumner, L. W.; Amberg, A.; Barrett, D.; Beale, M. H.; Beger, R.; Daykin, C. A.; Fan, T. W. M.; Fiehn, O.; Goodacre, R.; Griffin, J. L.; Hankemeier, T.; Hardy, N.; Harnly, J.; Higashi, R.; Kopka, J.; Lane, A. N.; Lindon, J. C.; Marriott, P.; Nicholls, A. W.; Reily, M. D.; Thaden, J. J.; Viant, M. R., Proposed minimum reporting standards for chemical analysis Chemical Analysis Working Group (CAWG) Metabolomics Standards Initiative (MSI). Metabolomics : Official journal of the Metabolomic Society 2007, 3 (3), 211 221.

82. Smoot, M. E.; Ono, K.; Ruscheinski, J.; Wang, P.-L.; Ideker, T., Cytoscape 2.8: new features for data integration and network visualization. Bioinformatics 2010, 27 (3), 431-432.

83. Shannon, P.; Markiel, A.; Ozier, O.; Baliga, N. S.; Wang, J. T.; Ramage, D.; Amin, N.; Schwikowski, B.; Ideker, T., Cytoscape: a software environment for integrated models of biomolecular interaction networks. Genome research 2003, 13 (11), 2498-2504.

84. Cline, M. S.; Smoot, M.; Cerami, E.; Kuchinsky, A.; Landys, N.; Workman, C.; Christmas, R.; Avila-Campilo, I.; Creech, M.; Gross, B., Integration of biological networks and gene expression data using Cytoscape. Nature protocols 2007, 2 (10), 2366.

85. Watrous, J.; Roach, P.; Alexandrov, T.; Heath, B. S.; Yang, J. Y.; Kersten, R. D.; van der Voort, M.; Pogliano, K.; Gross, H.; Raaijmakers, J. M., Mass spectral molecular networking of living microbial colonies. Proceedings of the National Academy of Sciences 2012, 109 (26), E1743-E1752.

86. Boya P, C. A.; Fernández-Marín, H.; Mejía, L. C.; Spadafora, C.; Dorrestein, P. C.; Gutiérrez, M., Imaging mass spectrometry and MS/MS molecular networking reveals chemical interactions among cuticular bacteria and pathogenic fungi associated with fungus-growing ants. Scientific Reports 2017, 7 (1), 5604.

87. Kofia, V.; Isserlin, R.; Buchan, A. M. J.; Bader, G. D., Social Network: a Cytoscape app for visualizing co-authorship networks. F1000Research 2015, 4, 481-481.

88. Zhou, H.; Shaverdian, A. A.; Jagadish, H. V.; Michailidis, G. In Multiple step social structure analysis with Cytoscape, 2009 IEEE Symposium on Visual Analytics Science and Technology, 12-13 Oct. 2009; 2009; pp 263-264.

89. Schmitt, T. M.; Hay, M. E.; Lindquist, N., Constraints on chemically mediated coevolution: multiple functions for seaweed secondary metabolites. Ecology 1995, 76 (1), 107-123.

90. Pereira, R. C.; Da Gama, B., Macroalgal chemical defenses and their roles in structuring tropical marine communities. In Algal chemical ecology, Springer: 2008; pp 25-55.

91. Cabrita, M. T.; Vale, C.; Rauter, A. P., Halogenated Compounds from Marine Algae. Marine Drugs 2010, 8 (8), 2301-2317.

92. Blunt, J. W.; Copp, B.; Keyzers, R. A.; Munro, M. H.; Prinsep, M. R., Marine natural products. 2014. 
93. Blunt, J. W.; Copp, B. R.; Keyzers, R. A.; Munro, M. H.; Prinsep, M. R., Marine natural products. Natural product reports 2013, 30 (2), 237-323.

94. Blunt, J. W.; Copp, B. R.; Keyzers, R. A.; Munro, M. H.; Prinsep, M. R., Marine natural products. Natural Product Reports 2015, 32 (2), 116-211.

95. Blunt, J. W.; Copp, B. R.; Keyzers, R. A.; Munro, M. H.; Prinsep, M. R., Marine natural products. 2016.

96. Leal, M. C.; Munro, M. H.; Blunt, J. W.; Puga, J.; Jesus, B.; Calado, R.; Rosa, R.; Madeira, C., Biogeography and biodiscovery hotspots of macroalgal marine natural products. Natural product reports 2013, 30 (11), 1380-1390.

97. Ormond, R.; Banaimoon, S., Ecology of intertidal macroalgal assemblages on the Hadramout coast of southern Yemen, an area of seasonal upwelling. Marine Ecology-Progress Series 1994, 105, 105-105.

98. Harizani, M.; loannou, E.; Roussis, V., The Laurencia paradox: An endless source of chemodiversity. In Progress in the Chemistry of Organic Natural Products 102, Springer: 2016; pp 91-252.

99. M.D. Guiry in Guiry, M. D. G., G.M. AlgaeBase. World-wide electronic publication. http://Www.algaebase.org (accessed November).

100. Silva, P. C.; Basson, P. W.; Moe, R. L., Catalogue of the Benthic Marine Algae of the Indian Ocean. University of California Press 1996.

101. Masuda, M.; Takahashi, Y.; Okamoto, K.; Matsuo, Y.; Suzuki, M., Morphology and halogenated secondary metabolites of Laurencia snackeyi (Weber-van Bosse) stat. nov. (Ceramiales, Rhodophyta). European Journal of Phycology 1997, 32 (3), 293-301.

102. Blunt, J. W.; Copp, B. R.; Keyzers, R. A.; Munro, M. H. G.; Prinsep, M. R., Marine natural products. Natural Product Reports 2015, 32 (2), 116-211.

103. Vairappan, C. S.; Kamada, T.; Lee, W.-W.; Jeon, Y.-J., Anti-inflammatory activity of halogenated secondary metabolites of Laurencia snackeyi (Webervan Bosse) Masuda in LPS-stimulated RAW 264.7 macrophages. Journal of Applied Phycology 2013, 25 (6), 1805-1813.

104. Wijesinghe, W.; Kang, M.-C.; Lee, W.-W.; Lee, H.-S.; Kamada, T.; Vairappan, C. S.; Jeon, Y.-J., 5 [Beta]-Hydroxypalisadin B isolated from red alga Laurencia snackeyi attenuates inflammatory response in lipopolysaccharidestimulated RAW 264.7 macrophages. Algae 2014, 29 (4), 333.

105. Kamada, T.; Vairappan, C. S., Non-halogenated new sesquiterpenes from Bornean Laurencia snackeyi. Natural Product Research 2017, 31 (3), 333340.

106. Wijesinghe, W. A. J. P.; Kim, E.-A.; Kang, M.-C.; Lee, W.-W.; Lee, H.-S.; Vairappan, C. S.; Jeon, Y.-J., Assessment of anti-inflammatory effect of 5Bhydroxypalisadin $B$ isolated from red seaweed Laurencia snackeyi in zebrafish embryo in vivo model. Environmental Toxicology and Pharmacology 2014, 37 (1), 110-117.

107. Angyal, S. J., The composition and conformation of sugars in solution. Angewandte Chemie International Edition in English 1969, 8 (3), 157-166. 
108. Ren, L.; Zhang, J.; Ma, H.; Sun, L.; Zhang, X.; Yu, G.; Guan, H.; Wang, W.; $\mathrm{Li}, \mathrm{C}$., Synthesis and Anti-Influenza A Virus Activity of 6'-amino-6'-deoxyglucoglycerolipids Analogs. Marine drugs 2016, 14 (6), 116.

109. Zhang, J.; Li, C.; Yu, G.; Guan, H., Total synthesis and structure-activity relationship of glycoglycerolipids from marine organisms. Marine drugs 2014, 12 (6), 3634-3659.

110. Cheng-Sánchez, I.; Sarabia, F., Chemistry and Biology of Bioactive Glycolipids of Marine Origin. Marine Drugs 2018, 16 (9), 294.

111. Barnathan, G.; Couzinet-Mossion, A.; Wielgosz-Collin, G., Glycolipids from marine invertebrates. Outstanding Marine Molecules 2014, 99-162.

112. Al-Fadhli, A.; Wahidulla, S.; D'souza, L., Glycolipids from the red alga Chondria armata (Kütz.) Okamura. Glycobiology 2006, 16 (10), 902-915.

113. Zhou, B.-N.; Tang, S.; Johnson, R. K.; Mattern, M. P.; Lazo, J. S.; Sharlow, E. R.; Harich, K.; Kingston, D. G. I., New glycolipid inhibitors of Myt1 kinase. Tetrahedron 2005, 61 (4), 883-887.

114. Andersen, R. J.; Taglialatela-Scafati, O., Avrainvilloside, a 6-Deoxy-6aminoglucoglycerolipid from the Green Alga Avrainvillea nigricans. Journal of Natural Products 2005, 68 (9), 1428-1430.

115. Zou, Y.; Li, Y.; Kim, M.-M.; Lee, S.-H.; Kim, S.-K., Ishigoside, a new glyceroglycolipid isolated from the brown alga Ishige okamurae. Biotechnology and Bioprocess Engineering 2009, 14 (1), 20-26.

116. Zuccarello, G. C.; Lokhorst, G. M., Molecular phylogeny of the genus Tribonema (Xanthophyceae) using rbc $L$ gene sequence data: monophyly of morphologically simple algal species. Phycologia 2005, 44 (4), 384-392.

117. Saunders, G. W., Applying DNA barcoding to red macroalgae: a preliminary appraisal holds promise for future applications. Philosophical transactions of the Royal Society of London. Series B, Biological sciences 2005, 360 (1462), 1879-1888.

118. El Sayed, K. A.; Kelly, M.; Kara, U. A. K.; Ang, K. K. H.; Katsuyama, I.; Dunbar, D. C.; Khan, A. A.; Hamann, M. T., New Manzamine Alkaloids with Potent Activity against Infectious Diseases. Journal of the American Chemical Society 2001, 123 (9), 1804-1808.

119. Sirirath, S.; Tanaka, J.; Ohtani, I. I.; Ichiba, T.; Rachmat, R.; Ueda, K.; Usui, T.; Osada, H.; Higa, T., Bitungolides A-F, New Polyketides from the Indonesian Sponge Theonella cf. swinhoei. Journal of Natural Products 2002, 65 (12), 1820-1823.

120. Angawi, R. F.; Bavestrello, G.; Calcinai, B.; Dien, H. A.; Donnarumma, G.; Tufano, M. A.; Paoletti, I.; Grimaldi, E.; Chianese, G.; Fattorusso, E., Aurantoside J: A new tetramic acid glycoside from Theonella swinhoei. Insights into the antifungal potential of aurantosides. Marine drugs 2011, 9 (12), 2809-2817. 
121. Aratake, S.; Trianto, A.; Hanif, N.; De Voogd, N.; Tanaka, J., A New Polyunsaturated Brominated Fatty Acid from a Haliclona Sponge. Marine Drugs 2009, 7 (4), 523.

122. Aoki, S.; Matsui, K.; Wei, H.; Murakami, N.; Kobayashi, M., Structure-activity relationship of neuritogenic spongean acetylene alcohols, lembehynes. Tetrahedron 2002, 58 (27), 5417-5422.

123. Trianto, A.; Hermawan, I.; De Voogd, N. J.; Tanaka, J., Halioxepine, a new meroditerpene from an Indonesian sponge Haliclona sp. Chemical and Pharmaceutical Bulletin 2011, 59 (10), 1311-1313.

124. Salmoun, M.; Devijver, C.; Daloze, D.; Braekman, J.-C.; van Soest, R. W. M., 5-Hydroxytryptamine-Derived Alkaloids from Two Marine Sponges of the Genus Hyrtios. Journal of Natural Products 2002, 65 (8), 1173-1176.

125. Craig, K. S.; Williams, D. E.; Hollander, I.; Frommer, E.; Mallon, R.; Collins, K.; Wojciechowicz, D.; Tahir, A.; Van Soest, R.; Andersen, R. J., Novel sesterterpenoid and norsesterterpenoid RCE-protease inhibitors isolated from the marine sponge Hippospongia sp. Tetrahedron Letters 2002, 43 (27), 4801-4804.

126. Roy, M. C.; Tanaka, J.; de Voogd, N.; Higa, T., New Scalarane Class Sesterterpenes from an Indonesian Sponge, Phyllospongia sp. Journal of Natural Products 2002, 65 (12), 1838-1842.

127. Aoki, S.; Naka, Y.; Itoh, T.; Furukawa, T.; Rachmat, R.; Akiyama, S.-i.; Kobayashi, M., Lembehsterols A and B, Novel Sulfated Sterols Inhibiting Thymidine Phosphorylase, from the Marine Sponge <i>Petrosia strongylata</i>. Chemical and Pharmaceutical Bulletin 2002, 50 (6), 827830.

128. Braekman, J. C.; Daloze, D.; Devijver, C.; Dubut, D.; van Soest, R. W. M., A New C-20 Polyacetylene from the Sponge Callyspongia pseudoreticulata. Journal of Natural Products 2003, 66 (6), 871-872.

129. Wang, C.-Y.; Wang, B.-G.; Wiryowidagdo, S.; Wray, V.; van Soest, R.; Steube, K. G.; Guan, H.-S.; Proksch, P.; Ebel, R., Melophlins C-O, Thirteen Novel Tetramic Acids from the Marine Sponge Melophlus sarassinorum. Journal of Natural Products 2003, 66 (1), 51-56.

130. Tan, L. T.; Williamson, R. T.; Gerwick, W. H.; Watts, K. S.; McGough, K.; Jacobs, R., cis,cis- and trans,trans-Ceratospongamide, New Bioactive Cyclic Heptapeptides from the Indonesian Red Alga Ceratodictyon spongiosum and Symbiotic Sponge Sigmadocia symbiotica. The Journal of Organic Chemistry 2000, 65 (2), 419-425.

131. Rao, K. V.; Santarsiero, B. D.; Mesecar, A. D.; Schinazi, R. F.; Tekwani, B. L.; Hamann, M. T., New Manzamine Alkaloids with Activity against Infectious and Tropical Parasitic Diseases from an Indonesian Sponge. Journal of Natural Products 2003, 66 (6), 823-828. 
132. Segraves, N. L.; Lopez, S.; Johnson, T. A.; Said, S. A.; Fu, X.; Schmitz, F. J.; Pietraszkiewicz, H.; Valeriote, F. A.; Crews, P., Structures and cytotoxicities of fascaplysin and related alkaloids from two marine phyla-Fascaplysinopsis sponges and Didemnum tunicates. Tetrahedron Letters 2003, 44 (17), 34713475.

133. Aoki, S.; Wei, H.; Matsui, K.; Rachmat, R.; Kobayashi, M., Pyridoacridine Alkaloids Inducing Neuronal Differentiation in a Neuroblastoma Cell Line, from Marine Sponge Biemna fortis. Bioorganic \& Medicinal Chemistry 2003, 11 (9), 1969-1973.

134. Calcul, L.; Longeon, A.; Mourabit, A. A.; Guyot, M.; Bourguet-Kondracki, M.L., Novel alkaloids of the aaptamine class from an Indonesian marine sponge of the genus Xestospongia. Tetrahedron 2003, 59 (34), 6539-6544.

135. Linington, R. G.; Williams, D. E.; Tahir, A.; van Soest, R.; Andersen, R. J., Latonduines A and B, New Alkaloids Isolated from the Marine Sponge Stylissa carteri: Structure Elucidation, Synthesis, and Biogenetic Implications. Organic Letters 2003, 5 (15), 2735-2738.

136. Piña, I. C.; Sanders, M. L.; Crews, P., Puupehenone Congeners from an IndoPacific Hyrtios Sponge. Journal of Natural Products 2003, 66 (1), 2-6.

137. Yasman; Edrada, R. A.; Wray, V.; Proksch, P., New 9Thiocyanatopupukeanane Sesquiterpenes from the Nudibranch Phyllidia varicosa and Its Sponge-Prey Axinyssa aculeata. Journal of Natural Products 2003, 66 (11), 1512-1514.

138. Chianese, G.; Fattorusso, E.; Scala, F.; Teta, R.; Calcinai, B.; Bavestrello, G.; Dien, H. A.; Kaiser, M.; Tasdemir, D.; Taglialatela-Scafati, O., Manadoperoxides, a new class of potent antitrypanosomal agents of marine origin. Organic \& Biomolecular Chemistry 2012, 10 (35), 7197-7207.

139. Arai, M.; Yamano, Y.; Fujita, M.; Setiawan, A.; Kobayashi, M., Stylissamide $X$, a new proline-rich cyclic octapeptide as an inhibitor of cell migration, from an Indonesian marine sponge of Stylissa sp. Bioorganic \& Medicinal Chemistry Letters 2012, 22 (4), 1818-1821.

140. Wahba, A. E.; Fromentin, Y.; Zou, Y.; Hamann, M. T., Acantholactone, a new manzamine related alkaloid with an unprecedented $\delta$-lactone and $\varepsilon$-lactam ring system. Tetrahedron Letters 2012, 53 (47), 6329-6331.

141. Yamanokuchi, R.; Imada, K.; Miyazaki, M.; Kato, H.; Watanabe, T.; Fujimuro, M.; Saeki, Y.; Yoshinaga, S.; Terasawa, H.; Iwasaki, N.; Rotinsulu, H.; Losung, F.; Mangindaan, R. E. P.; Namikoshi, M.; de Voogd, N. J.; Yokosawa, H.; Tsukamoto, S., Hyrtioreticulins A-E, indole alkaloids inhibiting the ubiquitin-activating enzyme, from the marine sponge Hyrtios reticulatus. Bioorganic \& Medicinal Chemistry 2012, 20 (14), 4437-4442.

142. Fouad, M. A.; Debbab, A.; Wray, V.; Müller, W. E. G.; Proksch, P., New bioactive alkaloids from the marine sponge Stylissa sp. Tetrahedron 2012, 68 (49), 10176-10179. 
143. Mudianta, I. W.; Skinner-Adams, T.; Andrews, K. T.; Davis, R. A.; Hadi, T. A.; Hayes, P. Y.; Garson, M. J., Psammaplysin Derivatives from the Balinese Marine Sponge Aplysinella strongylata. Journal of Natural Products 2012, 75 (12), 2132-2143.

144. Ushiyama, S.; Umaoka, H.; Kato, H.; Suwa, Y.; Morioka, H.; Rotinsulu, H.; Losung, F.; Mangindaan, R. E.; De Voogd, N. J.; Yokosawa, H., Manadosterols $A$ and $B$, sulfonated sterol dimers inhibiting the Ubc13-Uev1A interaction, isolated from the marine sponge Lissodendryx fibrosa. Journal of natural products 2012, 75 (8), 1495-1499.

145. Costantino, V.; Della Sala, G.; Mangoni, A.; Perinu, C.; Teta, R., Blurring the Boundary between Bio- and Geohopanoids: Plakohopanoid, a C32 Biohopanoid Ester from Plakortis cf. lita. European Journal of Organic Chemistry 2012, 2012 (27), 5171-5176.

146. Rao, K. V.; Donia, M. S.; Peng, J.; Garcia-Palomero, E.; Alonso, D.; Martinez, A.; Medina, M.; Franzblau, S. G.; Tekwani, B. L.; Khan, S. I., Manzamine B and $E$ and ircinal $A$ related alkaloids from an Indonesian Acanthostrongylophora sponge and their activity against infectious, tropical parasitic, and Alzheimer's diseases. Journal of natural products 2006, 69 (7), 1034.

147. Fattorusso, E.; Romano, A.; Taglialatela-Scafati, O.; Bavestrello, G.; Bonelli, P.; Calcinai, B., Coelodiol and coeloic acid, ent-isocopalane diterpenes from the Indonesian sponge Coelocarteria cfr. singaporensis. Tetrahedron letters 2006, 47 (13), 2197-2200.

148. Aoki, S.; Watanabe, Y.; Sanagawa, M.; Setiawan, A.; Kotoku, N.; Kobayashi, M., Cortistatins A, B, C, and D, anti-angiogenic steroidal alkaloids, from the marine sponge Corticium simplex. Journal of the American Chemical Society 2006, 128 (10), 3148-3149.

149. Arai, M.; Kawachi, T.; Setiawan, A.; Kobayashi, M., Hypoxia-Selective Growth Inhibition of Cancer Cells by Furospinosulin-1, a Furanosesterterpene Isolated from an Indonesian Marine Sponge. ChemMedChem 2010, 5 (11), 1919-1926.

150. Fouad, M.; Edrada, R. A.; Ebel, R.; Wray, V.; Müller, W. E.; Lin, W. H.; Proksch, P., Cytotoxic isomalabaricane triterpenes from the marine sponge Rhabdastrella globostellata. Journal of natural products 2006, 69 (2), 211218.

151. Nagasawa, Y.; Ueoka, R.; Yamanokuchi, R.; Horiuchi, N.; Ikeda, T.; Rotinsulu, H.; Mangindaan, R. E.; Ukai, K.; Kobayashi, H.; Namikoshi, M., Isolation of salsolinol, a tetrahydroisoquinoline alkaloid, from the marine sponge Xestospongia cf. vansoesti as a proteasome inhibitor. Chemical and Pharmaceutical Bulletin 2011, 59 (2), 287-290.

152. Chianese, G.; Fattorusso, E.; Taglialatela-Scafati, O.; Bavestrello, G.; Calcinai, B.; Dien, H. A.; Ligresti, A.; Di Marzo, V., Desulfohaplosamate, a new phosphate-containing steroid from Dasychalina sp., is a selective cannabinoid CB 2 receptor ligand. Steroids 2011, 76 (10), 998-1002. 
153. Jadulco, R.; Brauers, G.; Edrada, R. A.; Ebel, R.; Wray, V.; Sudarsono; Proksch, P., New Metabolites from Sponge-Derived Fungi Curvularia lunata and Cladosporium herbarum. Journal of Natural Products 2002, 65 (5), 730 733.

154. Xu, J.; Takasaki, A.; Kobayashi, H.; Oda, T.; Yamada, J.; Mangindaan, R. E. P.; Ukai, K.; Nagai, H.; Namikoshi, M., Four New Macrocyclic Trichothecenes from Two Strains of Marine-derived Fungi of the Genus Myrothecium. J Antibiot 2006, 59 (8), 451-455.

155. Xu, J.; Nakazawa, T.; Ukai, K.; Kobayashi, H.; Mangindaan, R. E. P.; Wewengkang, D. S.; Rotinsulu, H.; Namikoshi, M., Tetrahydrobostrycin and 1-Deoxytetrahydrobostrycin, Two New Hexahydroanthrone Derivatives, from a Marine-derived Fungus Aspergillus sp. J Antibiot 2008, 61 (7), 415-419.

156. Tarman, K.; Palm, G. J.; Porzel, A.; Merzweiler, K.; Arnold, N.; Wessjohann, L. A.; Unterseher, M.; Lindequist, U., Helicascolide C, a new lactone from an Indonesian marine algicolous strain of Daldinia eschscholzii (Xylariaceae, Ascomycota). Phytochemistry Letters 2012, 5 (1), 83-86.

157. Tarman, K.; Lindequist, U.; Wende, K.; Porzel, A.; Arnold, N.; Wessjohann, L. A., Isolation of a New Natural Product and Cytotoxic and Antimicrobial Activities of Extracts from Fungi of Indonesian Marine Habitats. Marine Drugs 2011, 9 (3), 294-306.

158. Smith, C. J.; Abbanat, D.; Bernan, V. S.; Maiese, W. M.; Greenstein, M.; Jompa, J.; Tahir, A.; Ireland, C. M., Novel Polyketide Metabolites from a Species of Marine Fungi. Journal of Natural Products 2000, 63 (1), 142-145.

159. Washida, K.; Koyama, T.; Yamada, K.; Kita, M.; Uemura, D., Karatungiols A and $B$, two novel antimicrobial polyol compounds, from the symbiotic marine dinoflagellate Amphidinium sp. Tetrahedron letters 2006, 47 (15), 2521 2525.

160. Williamson, R. T.; Boulanger, A.; Vulpanovici, A.; Roberts, M. A.; Gerwick, W. H., Structure and absolute stereochemistry of phormidolide, a new toxic metabolite from the marine cyanobacterium Phormidium sp. The Journal of organic chemistry 2002, 67 (23), 7927-7936.

161. Itoh, T.; Kinoshita, M.; Aoki, S.; Kobayashi, M., Komodoquinone A, a Novel Neuritogenic Anthracycline, from Marine Streptomyces sp. KS3. Journal of Natural Products 2003, 66 (10), 1373-1377.

162. Anta, C.; González, N.; Santafé, G.; Rodríguez, J.; Jiménez, C., New Xenia diterpenoids from the Indonesian soft coral Xenia sp. Journal of natural products 2002, 65 (5), 766-768.

163. Anta, C.; González, N.; Rodríguez, J.; Jiménez, C., A New Secosterol from the Indonesian Octocoral Pachyclavularia $v$ iolacea. Journal of natural products 2002, 65 (9), 1357-1359.

164. González, N.; Barral, M. A.; Rodríguez, J.; Jiménez, C., New cytotoxic steroids from the gorgonian Isis hippuris. Structure-activity studies. Tetrahedron 2001, 57 (16), 3487-3497. 
165. González, N.; Rodríguez, J.; Jiménez, C., Didemniserinolipids A- C, Unprecedented Serinolipids from the Tunicate Didemnum sp. The Journal of organic chemistry 1999, 64 (15), 5705-5707.

166. Kiyota, H.; Dixon, D. J.; Luscombe, C. K.; Hettstedt, S.; Ley, S. V., Synthesis, Structure Revision, and Absolute Configuration of (+)-Didemniserinolipid B, a Serinol Marine Natural Product from a Tunicate Didemnum sp. Organic Letters 2002, 4 (19), 3223-3226.

167. Copp, B. R.; Jompa, J.; Tahir, A.; Ireland, C. M., Styelsamines AD: New tetracyclic pyridoacridine alkaloids from the Indonesian ascidian Eusynstyela latericius. Journal of organic chemistry 1998, 63 (22), 8024-8026.

168. Yamazaki, H.; Wewengkang, D. S.; Nishikawa, T.; Rotinsulu, H.; Mangindaan, R. E.; Namikoshi, M., Two New Tryptamine Derivatives, Leptoclinidamide and (-)-Leptoclinidamine B, from an Indonesian Ascidian Leptoclinides dubius. Marine drugs 2012, 10 (2), 349-357.

169. Chen, Y.-H.; Hwang, T.-L.; Su, Y.-D.; Chang, Y.-C.; Chen, Y.-H.; Hong, P.H.; Hu, L.-C.; Yen, W.-H.; Hsu, H.-Y.; Huang, S.-J., New 6-hydroxyeunicellins from a soft coral Cladiella sp. Chemical and Pharmaceutical Bulletin 2012, 60 (1), 160-163.

170. Putra, M. Y.; Ianaro, A.; Panza, E.; Bavestrello, G.; Cerrano, C.; Fattorusso, E.; Taglialatela-Scafati, O., Sinulasulfoxide and sinulasulfone, sulfurcontaining alkaloids from the Indonesian soft coral Sinularia sp. Tetrahedron Letters 2012, 53 (30), 3937-3939.

171. Putra, M. Y.; Bavestrello, G.; Cerrano, C.; Renga, B.; D'Amore, C.; Fiorucci, S.; Fattorusso, E.; Taglialatela-Scafati, O., Polyhydroxylated sterols from the Indonesian soft coral Sinularia sp. and their effect on farnesoid X-activated receptor. Steroids 2012, 77 (5), 433-440.

172. Fattorusso, E.; Luciano, P.; Putra, M. Y.; Taglialatela-Scafati, O.; Ianaro, A.; Panza, E.; Bavestrello, G.; Cerrano, C., Chloroscabrolides, chlorinated norcembranoids from the Indonesian soft coral Sinularia sp. Tetrahedron 2011, 67 (41), 7983-7988. 


\section{APPENDIX A: MARINE NATURAL PRODUCTS RESEARCH IN INDONESIA}

Table 1. Marine natural product from sponges

\begin{tabular}{|c|c|c|c|c|}
\hline No & Species & Compound and bioactive & Location & Literature \\
\hline 1. & $\begin{array}{l}\text { Sidonops } \\
\text { microspinosa }\end{array}$ & $\begin{array}{l}\text { Microspinosamide: inhibits cytopathic } \\
\text { effect of HIV-1 infection }\end{array}$ & $\begin{array}{l}\text { South East } \\
\text { Sulawesi }\end{array}$ & 36 \\
\hline 2. & Family Petrosiidae & $\begin{array}{l}\text { Manzamine: 8-hydroxymanzamine A, } \\
\text { manzamine F, along with the } \\
\text { unprecedented manzamine dimer, neo- } \\
\text { kauluamine. They show antimaria } \\
\text { activity against Plasmodium berghei }\end{array}$ & $\begin{array}{l}\text { North } \\
\text { Sulawesi }\end{array}$ & 118 \\
\hline 3. & Theonella swinhoei & $\begin{array}{l}\text { Bitungolides A-F; Dual-specificity against } \\
\text { phosphatase VHR }\end{array}$ & $\begin{array}{l}\text { North } \\
\text { Sulawesi }\end{array}$ & 119 \\
\hline & & $\begin{array}{l}\text { Aurantoside } \mathrm{F}-\mathrm{J} \text { are a new compound and } \\
\text { showed a detectable antifungal activity }\end{array}$ & $\begin{array}{c}\text { North } \\
\text { Sulawesi }\end{array}$ & 120 \\
\hline 4. & Haliclona sp. & $\begin{array}{l}\text { Brominated fatty acid showed moderate } \\
\text { cytotoxicity against rat bladder epithelial } \\
\text { cells) } \\
\text { Acetylene alcohols: lembehynes B and C. } \\
\text { It showed neuritogenic activity against } \\
\text { neuroblastoma cells } \\
\text { Halioxepine showed moderate } \\
\text { cytotoxicity against NBT-T2 cells and } \\
\text { antioxidant activity }\end{array}$ & $\begin{array}{l}\text { Alor Island, } \\
\text { East Nusa } \\
\text { Tenggara } \\
\text { South } \\
\text { Sulawesi } \\
\text { Buton Island, } \\
\text { Southeast } \\
\text { Sulawesi }\end{array}$ & 121122123 \\
\hline 5. & $\begin{array}{l}\text { Hyrtios reticulatus } \\
\text { and Hyrtios erectus }\end{array}$ & $\begin{array}{l}\text { 1,6-dihydroxy-1,2,3,4-tetrahydro-B- } \\
\text { carboline; hyrtiosulawesine }\end{array}$ & $\begin{array}{l}\text { South } \\
\text { Sulawesi }\end{array}$ & 124 \\
\hline 6. & Hippospongia sp. & $\begin{array}{l}\text { Sesterterpenoid: barangcadoic acid A and } \\
\text { rhopaloic acids A }\end{array}$ & $\begin{array}{l}\text { South } \\
\text { Sulawesi }\end{array}$ & 125 \\
\hline 7. & Phyllospongia sp. & Scalarane sesterterpenoids & $\begin{array}{l}\text { South } \\
\text { Sulawesi }\end{array}$ & 126 \\
\hline 8. & $\begin{array}{l}\text { Petrosia } \\
\text { strongylata }\end{array}$ & $\begin{array}{l}\text { Sulfated sterols: lembehsterols A-B show } \\
\text { inhibitory activity against thymidine } \\
\text { phosphorylase (angiogenesis in solid } \\
\text { tumors) }\end{array}$ & Sulawesi & 127 \\
\hline 9. & $\begin{array}{l}\text { Callyspongia } \\
\text { pseudoreticulata }\end{array}$ & $\begin{array}{l}\text { Diyne which is toxic to brine shrimp } \\
\text { assay }\end{array}$ & $\begin{array}{l}\text { South } \\
\text { Sulawesi }\end{array}$ & 128 \\
\hline 10. & $\begin{array}{l}\text { Melophlus } \\
\text { sarassinorum }\end{array}$ & $\begin{array}{l}\text { Tetramic acid: melophlin C is an } \\
\text { antimicrobial active against Bacillus } \\
\text { subtilis and Staphylococcus aureus, also } \\
\text { antifungal against Candida albicans, } \\
\text { while melophlins D-O (less active) }\end{array}$ & $\begin{array}{l}\text { South } \\
\text { Sulawesi }\end{array}$ & 129 \\
\hline 11. & $\begin{array}{l}\text { Sigmadocia } \\
\text { symbiotica } \\
\text { (symbiont with alga } \\
\text { Ceratodictyon } \\
\text { spongiosum) }\end{array}$ & $\begin{array}{l}\text { Ceratospongamide: cis,cis- and } \\
\text { trans, trans- isomers antiinflammation } \\
\text { and inhibit the expression of a human- } \\
\text { sPLA2promoter-based reporter }\end{array}$ & $\begin{array}{l}\text { Biaro Island, } \\
\text { South } \\
\text { Sulawesi }\end{array}$ & 130 \\
\hline 12. & NA & $\begin{array}{l}\text { Manzamine alkaloids which has } \\
\text { bioactivity against malaria, TB, and } \\
\text { leishmaniasis }\end{array}$ & $\begin{array}{l}\text { South } \\
\text { Sulawesi }\end{array}$ & 131 \\
\hline
\end{tabular}




\begin{tabular}{|c|c|c|c|c|}
\hline No & Species & Compound and bioactive & Location & Literature \\
\hline 13. & $\begin{array}{l}\text { Fascaplysinopsis } \\
\text { reticulate }\end{array}$ & $\begin{array}{l}\text { 3-bromofascaplysin, } 14- \\
\text { bromoreticulatine, and 14- } \\
\text { bromoreticulatate }\end{array}$ & Indonesia & 132 \\
\hline 14. & Biemna fortis & $\begin{array}{l}\text { Labuanine is a neuronal differentiation } \\
\text { inducer against neuroblastoma }\end{array}$ & $\begin{array}{l}\text { West Flores, } \\
\text { East Nusa } \\
\text { Tenggara }\end{array}$ & 133 \\
\hline 15. & Xestospongia sp. & $\begin{array}{l}\text { Aaptamine antibacterial against } S \text {. } \\
\text { aureus, } E \text {. coli, } V \text {. anguillarum; also } \\
\text { antifungal against } C \text {. tropicalis) }\end{array}$ & Jakarta & 134 \\
\hline 16. & Stylissa carteri & Oroidin: latonduines A-B & Latondu & 135 \\
\hline 17. & Hyrtios sp. & Merosesquiterpenes: puupehenone & $\begin{array}{l}\text { Island, South } \\
\text { Sulawesi } \\
\text { North }\end{array}$ & 136 \\
\hline 18. & $\begin{array}{l}\text { Axinyssa aculeate } \\
\text { (also its mollusk } \\
\text { nudibranch } \\
\text { predator Phyllidia } \\
\text { varicose) }\end{array}$ & $\begin{array}{l}\text { Sesquiterpenoids: } 9 \text { - } \\
\text { thiocyanatopupukeanane which weakly } \\
\text { and moderately antifungal } \\
\text { against } B \text {. subtilis and C. albicans }\end{array}$ & $\begin{array}{c}\text { Sulawesi } \\
\text { Thousands } \\
\text { Island, } \\
\text { Jakarta }\end{array}$ & 137 \\
\hline 19. & Plakortis cfr. lita & $\begin{array}{l}\text { Plakortin, manadoperoxides A-D and } \\
\text { peroxyplakoric ester B3. Show } \\
\text { antiprotozoal activity against } \\
\text { Trypanosoma brucei rhodesiense }\end{array}$ & $\begin{array}{c}\text { North } \\
\text { Sulawesi }\end{array}$ & 138 \\
\hline 20. & Stylissa sp. & $\begin{array}{l}\text { Octapeptide stylissamide which inhibit } \\
\text { HeLa cell migration }\end{array}$ & Biak, Papua & 139 \\
\hline 21. & $\begin{array}{l}\text { Acanthostrongylop } \\
\text { hora sp. }\end{array}$ & Acantholactone & $\begin{array}{l}\text { North } \\
\text { Sulawesi }\end{array}$ & 140 \\
\hline 22. & Hyrtios reticulatus & $\begin{array}{l}\text { Hyrtioreticulins } A \text { against the formation } \\
\text { of an E1-ubiquitin activating enzyme } \\
\text { inhibitor }\end{array}$ & $\begin{array}{l}\text { North } \\
\text { Sulawesi }\end{array}$ & 141 \\
\hline 23. & Stylissa sp. & $\begin{array}{l}\text { Stevesines cytotoxicity against mouse } \\
\text { lymphoma cell line and } \\
\text { debromolatonduines }\end{array}$ & $\begin{array}{l}\text { Derawan } \\
\text { Island, East }\end{array}$ & 142 \\
\hline 24. & $\begin{array}{l}\text { Aplysinella } \\
\text { strongylata }\end{array}$ & $\begin{array}{l}\text { 19-Hydroxypsammaplysin } \mathrm{E} \text { showed } \\
\text { modest inhibition of chloroquine- } \\
\text { sensitive } P \text { falciparum }\end{array}$ & $\begin{array}{l}\text { Kalimantan } \\
\text { Bali }\end{array}$ & 143 \\
\hline 25. & $\begin{array}{l}\text { Lissodendryx } \\
\text { fibrosa }\end{array}$ & $\begin{array}{l}\text { Sterols: manadosterols } A \text { and } B \text {, both } \\
\text { showed potential as anticancer agents }\end{array}$ & North Sulawesi & 144 \\
\hline 26. & Plakortis lita & hopanoid glycoside: plakohopanoid & North Sulawesi & 145 \\
\hline 27. & $\begin{array}{l}\text { Acanthostrongylop } \\
\text { hora sp. }\end{array}$ & $\begin{array}{l}\text { Manzamine-type alkaloids: } 12,28- \\
\text { oxamanzamine } \mathrm{E}, 12,34-0 x a-6- \\
\text { hydroxymanzamine } \mathrm{E}, 8- \\
\text { hydroxymanzamine } \mathrm{B} \text { and } 12,28- \\
\text { oxaircinal. They are showed significant } \\
\text { inhibitory enzyme implicated in } \\
\text { Alzheimer's disease pathology }\end{array}$ & North Sulawesi & 146 \\
\hline 28. & $\begin{array}{l}\text { Coelocarteria } \\
\text { cfr.singaporensis }\end{array}$ & $\begin{array}{l}\text { Ent-isocopalane diterpenes: coelodiol } \\
\text { and coeloic acid. Inhibit human gastric } \\
\text { adenocarcinoma }\end{array}$ & North Sulawesi & 147 \\
\hline 29. & Corticium simplex & $\begin{array}{l}\text { Steroidal Alkaloids: Cortistatins A-D, an } \\
\text { anti-angiogenic activity }\end{array}$ & $\begin{array}{l}\text { Flores Island, } \\
\text { East Nusa } \\
\text { Tenggara }\end{array}$ & 148 \\
\hline 30. & $\begin{array}{l}\text { Dactylospongia } \\
\text { elegans }\end{array}$ & $\begin{array}{l}\text { Furanosesterterpene: Furospinosulin-1, } \\
\text { an antiproliferative activity against } \\
\text { human prostate cancer and antitumor } \\
\text { activity }\end{array}$ & Indonesia & 149 \\
\hline
\end{tabular}




\begin{tabular}{|c|c|c|c|c|}
\hline No & Species & Compound and bioactive & Location & Literature \\
\hline \multirow[t]{2}{*}{31.} & \multirow{2}{*}{$\begin{array}{l}\text { Rhabdastrella } \\
\text { globostellata }\end{array}$} & \multirow{2}{*}{$\begin{array}{l}\text { Globostellatic acids } A \text { and } D \text { and } \\
\text { stelliferin riboside; new natural } \\
\text { products. They show selectively active } \\
\text { against mouse lymphoma cell }\end{array}$} & Kapoposang & 150 \\
\hline & & & $\begin{array}{l}\text { Island, South } \\
\text { Sulawesi }\end{array}$ & \\
\hline 32. & $\begin{array}{l}\text { Xestospongia cf. } \\
\text { vansoesti }\end{array}$ & $\begin{array}{l}\text { Salsolinol and its derivates norsalsolinol, } \\
\text { cis-4-hydroxysalsolinol, and trans-4- } \\
\text { hydroxysalsolinol. Show inhibition } \\
\text { activity against chymotrypsin }\end{array}$ & North Sulawesi & 151 \\
\hline 33. & Dasychalina sp. & $\begin{array}{l}\text { Desulfohaplosamate that is a selective } \\
\text { cannabinoid CB2-receptor ligand }\end{array}$ & South Sulawesi & 152 \\
\hline
\end{tabular}

Table 2. Marine natural products from fungi

\begin{tabular}{|c|c|c|c|c|}
\hline No & Species & Compound and bioactive & Location & Literature \\
\hline 1. & $\begin{array}{l}\text { Curvularia lunata } \\
\text { (symbiont with } \\
\text { sponge Niphates } \\
\text { olemda) }\end{array}$ & $\begin{array}{l}\text { Lunatin antibacterial against } S \text {. } \\
\text { aureus, } E \text {. coli and } B \text {. subtilis but } \\
\text { inactive against } C \text {. albicans }\end{array}$ & Bali & 153 \\
\hline 2. & $\begin{array}{l}\text { Cladosporium } \\
\text { herbarum } \\
\text { (symbiont with } \\
\text { sponge } \\
\text { Callyspongia } \\
\text { aerizusa) }\end{array}$ & $\begin{array}{l}\text { Phthalide herbaric acid show no } \\
\text { activity; furan show activity against } \\
\text { Bacillus subtilis and Staphylococcus } \\
\text { aureus }\end{array}$ & Bali & 153,40 \\
\hline 3. & $\begin{array}{l}\text { Penicillium cf. } \\
\text { montanense from } \\
\text { sponge } \\
\text { Xestospongia } \\
\text { exigua }\end{array}$ & $\begin{array}{l}\text { Xestodecalactones } \mathrm{A}-\mathrm{C} \text { but only } \\
\text { xestodecalactones } \mathrm{B} \text { active against } C \text {. } \\
\text { albicans }\end{array}$ & Bali & 41 \\
\hline 4. & $\begin{array}{l}\text { Myrothecium sp. } \\
\text { From unidentified } \\
\text { sponge }\end{array}$ & $\begin{array}{l}\text { Trichothecenes: roridin R cytotoxic } \\
\text { to L1210 cells }\end{array}$ & North Sulawesi & 154 \\
\hline 5. & $\begin{array}{l}\text { Aspergillus sp. } \\
\text { from unidentified } \\
\text { alga }\end{array}$ & $\begin{array}{l}\text { Hexahydroanthrones: } \\
\text { tetrahydrobostrycin and } 1 \text { - } \\
\text { deoxytetrahydrobostrycin. Both show } \\
\text { weak antibacterial activity against } \\
\text { Staphylococcus aureus and } 1 \text { - } \\
\text { deoxytetrahydrobostrycin also } \\
\text { against Escherichia coli }\end{array}$ & North Sulawesi & 155 \\
\hline 6. & $\begin{array}{l}\text { Endophytic } \\
\text { Daldinia } \\
\text { eschscholzii from } \\
\text { alga Gracilaria sp. }\end{array}$ & $\begin{array}{l}\text { Lactone, antifungal against } \\
\text { Cladosporium cucumerinum }\end{array}$ & South Sulawesi & 156 \\
\hline 7. & $\begin{array}{l}\text { Unidentified fungi } \\
\text { from unknown alga }\end{array}$ & $\begin{array}{l}\text { Naphthalene, fungicidal against } \\
\text { Cladosporium cucumerinum }\end{array}$ & $\begin{array}{l}\text { East and West } \\
\text { Java, and North } \\
\text { Jakarta }\end{array}$ & 157 \\
\hline 8. & $\begin{array}{l}\text { Unidentified fungi } \\
\text { from unknown } \\
\text { sponge }\end{array}$ & $\begin{array}{l}\text { Hexaketide: iso-cladospolide B, seco- } \\
\text { patulolide C; Macrolides: } \\
\text { pandangolide } 1 \text { and pandangolide } 2 \text {, } \\
\text { cladospolide B }\end{array}$ & South Sulawesi & 158 \\
\hline
\end{tabular}


Table 3. Other group of marine natural products from invertebrate (dinoflagellate, cyanobacteria bacteria, coelenterates, tunicates, cnidarian)

\begin{tabular}{|c|c|c|c|c|}
\hline No & Species & Compound and bioactive & Location & Literature \\
\hline 1. & $\begin{array}{l}\text { Amphidinium sp. as } \\
\text { symbiont of marine } \\
\text { flatworm }\end{array}$ & $\begin{array}{l}\text { Polyols: karatungiols } \mathrm{A} \text { and } \mathrm{B} \text { howed } \\
\text { antifungal activity against Aspergillus } \\
\text { niger and antiprotozoan activity against } \\
\text { Trichomonas foetus }\end{array}$ & North Sulawesi & 159 \\
\hline 2. & Phormidium sp. & $\begin{array}{l}\text { Phormidolide, show activity against } \\
\text { brine shrimp tocix }\end{array}$ & Sulawesi Island & 160 \\
\hline 3. & Streptomyces sp. & $\begin{array}{l}\text { komodoquinone } A \text { dose-dependent } \\
\text { neuritogenic activity against the } \\
\text { neuroblastoma cell and B }\end{array}$ & $\begin{array}{l}\text { Komodo Island, } \\
\text { East Nusa } \\
\text { Tenggara }\end{array}$ & 161 \\
\hline 4. & Xenia sp. & xeniolide $\mathrm{F}$ and 9-hydroxyxeniolide $\mathrm{F}$ & North Sulawesi & 162 \\
\hline 5. & $\begin{array}{l}\text { Pachyclavularia } \\
\text { violacea }\end{array}$ & Sterols: ecosterol & North Sulawesi & 163 \\
\hline 6. & Isis hippuris & polyoxygenated sterols & Sulawesi Island & 164 \\
\hline 7. & Didemnum sp. & $\begin{array}{l}\text { (+)-didemniserinolipid B then revised as } \\
\text { 31-sulfate }\end{array}$ & South Sulawesi & 165,166 \\
\hline 8. & $\begin{array}{l}\text { Eusynstyela } \\
\text { latericius }\end{array}$ & $\begin{array}{l}\text { Hydroxylpyridoacridine alkaloid: } \\
\text { styelsamine C }\end{array}$ & South Sulawesi & 167 \\
\hline 9. & $\begin{array}{l}\text { Leptoclinides } \\
\text { dubius }\end{array}$ & $\begin{array}{l}\text { Leptoclinidamide and }(R) \text { - } \\
\text { leptoclinidamine B }\end{array}$ & North Sulawesi & 168 \\
\hline 10. & Cladiella sp. & $\begin{array}{l}\text { 6-hydroxyeunicellin diterpenoids, } \\
\text { cladieunicellin G and 6-epi- } \\
\text { cladieunicellin F }\end{array}$ & Indonesia & 169 \\
\hline \multirow[t]{3}{*}{11.} & Sinularia sp. & $\begin{array}{l}\text { Llkaloids: sinulasulfoxide and } \\
\text { sinulasulfone. Sinulasulfoxide proved to } \\
\text { moderately inhibit LPS-induced NO } \\
\text { release }\end{array}$ & North Sulawesi & 170 \\
\hline & & Sterols: gorgosterol & North Sulawesi & 171 \\
\hline & & norcembranes chloroscabrolide $A$ and $B$ & North Sulawesi & 172 \\
\hline
\end{tabular}




\section{APPENDIX B: MACROALGAE COLLECTED FROM WEST TIMOR WATERS, INDONESIA}

\begin{tabular}{|l|l|l|l|}
\hline 1. & $\begin{array}{l}\text { WEM_01_001 } \\
\text { Sargassum sp1 } \\
\text { (Brown algae) }\end{array}$ & $\begin{array}{l}\text { Sulamu } \\
\text { Beach }\end{array}$ \\
\hline 2 & $\begin{array}{l}\text { WEM_01_002 } \\
\text { Sargassum sp2 } \\
\text { (Brown algae) }\end{array}$ & Wem_Ol_001 & Sulamu \\
Beach
\end{tabular}




\begin{tabular}{|c|c|c|c|}
\hline 5 & $\begin{array}{l}\text { WEM_04_003 } \\
\text { (Turbinaria } \\
\text { sp2) } \\
\text { Brown algae }\end{array}$ & wem_-04.003 & Akle Beach \\
\hline 6 & $\begin{array}{l}\text { WEM_04_006 } \\
\text { Sargassum sp3 } \\
\text { (Brown algae) }\end{array}$ & WEM-04-006 & 更 \\
\hline 7 & $\begin{array}{l}\text { WEM_04_010 } \\
\text { Sargassum sp4 } \\
\text { (Brown algae) }\end{array}$ & $\begin{array}{l}\text { Defla } \\
\text { WEM-04-010 }\end{array}$ & Akle Beach \\
\hline 8 & $\begin{array}{l}\text { WEM_04_019 } \\
\text { Padina sp2 } \\
\text { (Brown algae) }\end{array}$ & Wem-04-019 & Akle Beach \\
\hline
\end{tabular}




\begin{tabular}{|l|l|l|l|}
\hline 9 & $\begin{array}{l}\text { WEM_05_002 } \\
\text { Dictyota sp } \\
\text { (Brown algae) }\end{array}$ & $\begin{array}{l}\text { Tablolong } \\
\text { Beach }\end{array}$ \\
\hline 10 & $\begin{array}{l}\text { WEM_05_005 } \\
\text { Sargassum sp5 } \\
\text { (Brown algae) }\end{array}$ & & Tablolong \\
& & &
\end{tabular}




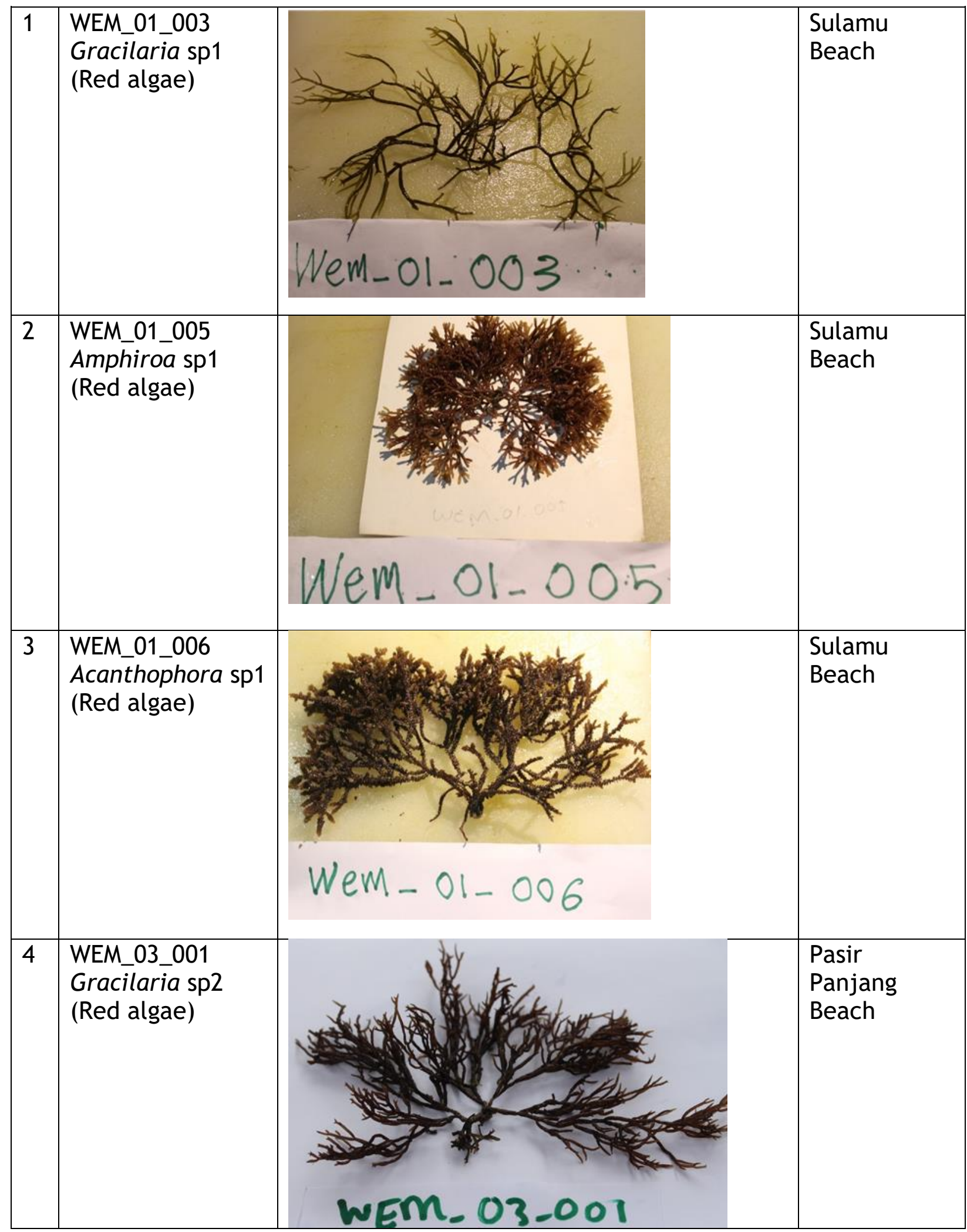




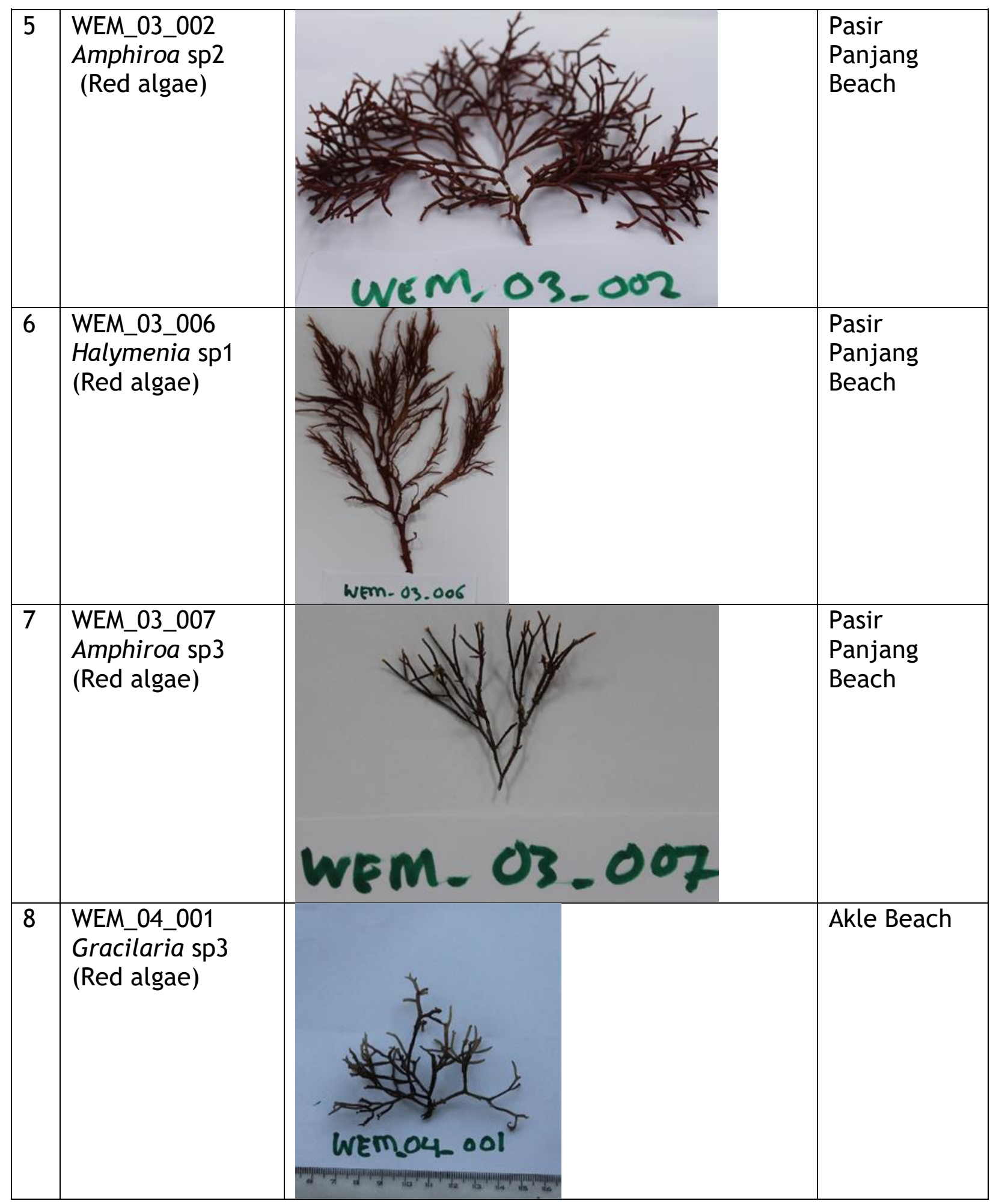




\begin{tabular}{|c|c|c|c|}
\hline 9 & $\begin{array}{l}\text { WEM_04_004 } \\
\text { Galaxaura sp1 } \\
\text { (Red algae) }\end{array}$ & 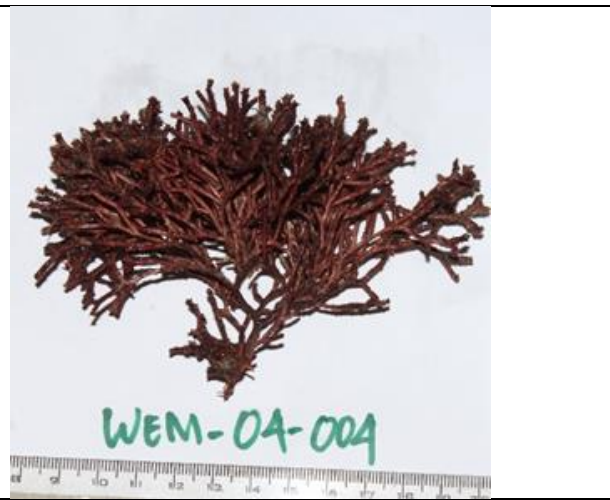 & Akle Beach \\
\hline 10 & $\begin{array}{l}\text { WEM_04_005 } \\
\text { Amphiroa sp4 } \\
\text { (Red algae) }\end{array}$ & WEM-04-005 & Akle Beach \\
\hline 11 & $\begin{array}{l}\text { WEM_04_009 } \\
\text { Acanthophora sp2 } \\
\text { (Red algae) }\end{array}$ & 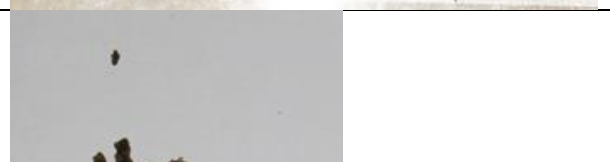 & Akle Beach \\
\hline 12 & $\begin{array}{l}\text { WEM_04_017 } \\
\text { Acanthophora sp3 } \\
\text { (Red algae) }\end{array}$ & & Akle Beach \\
\hline
\end{tabular}




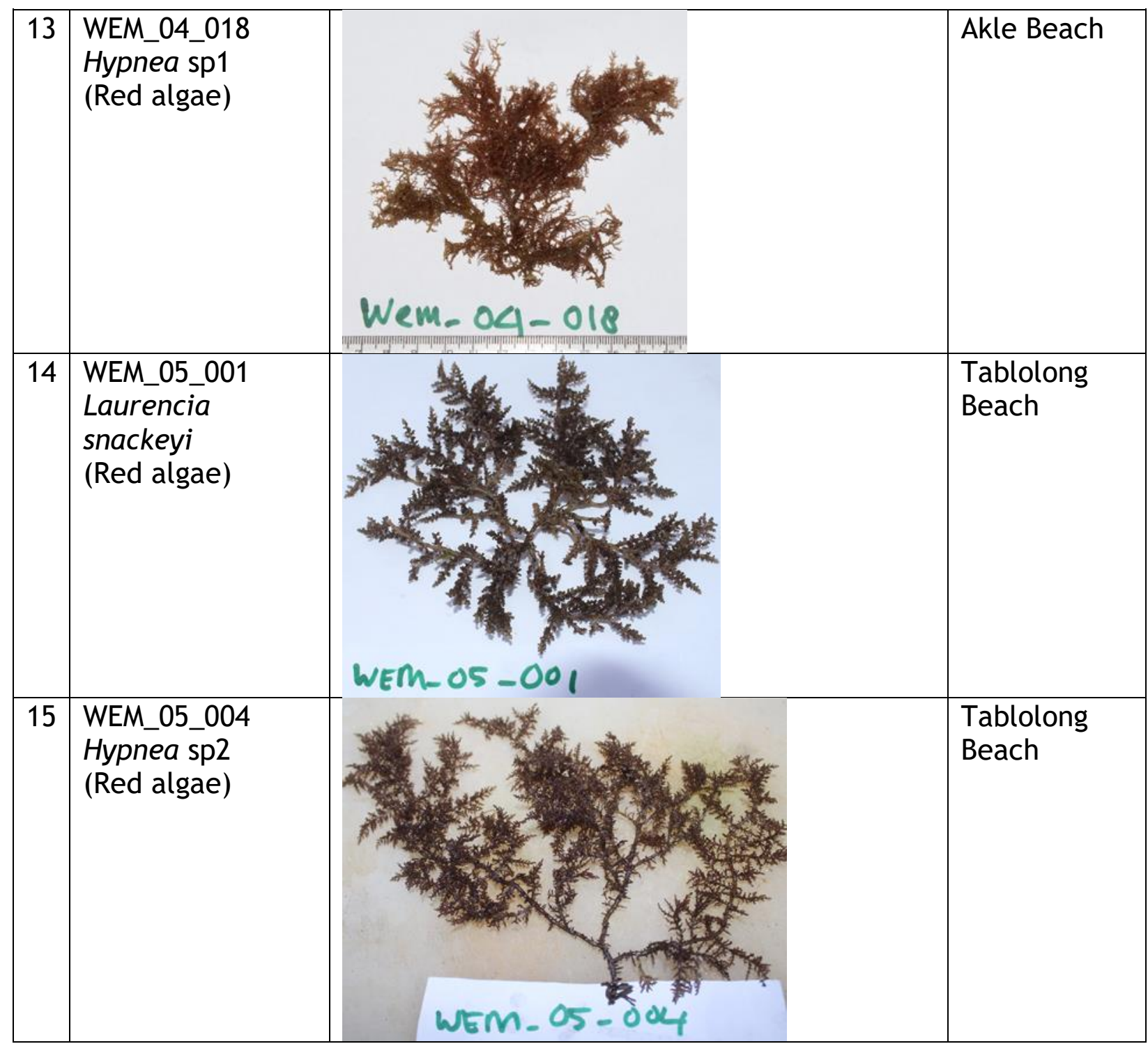




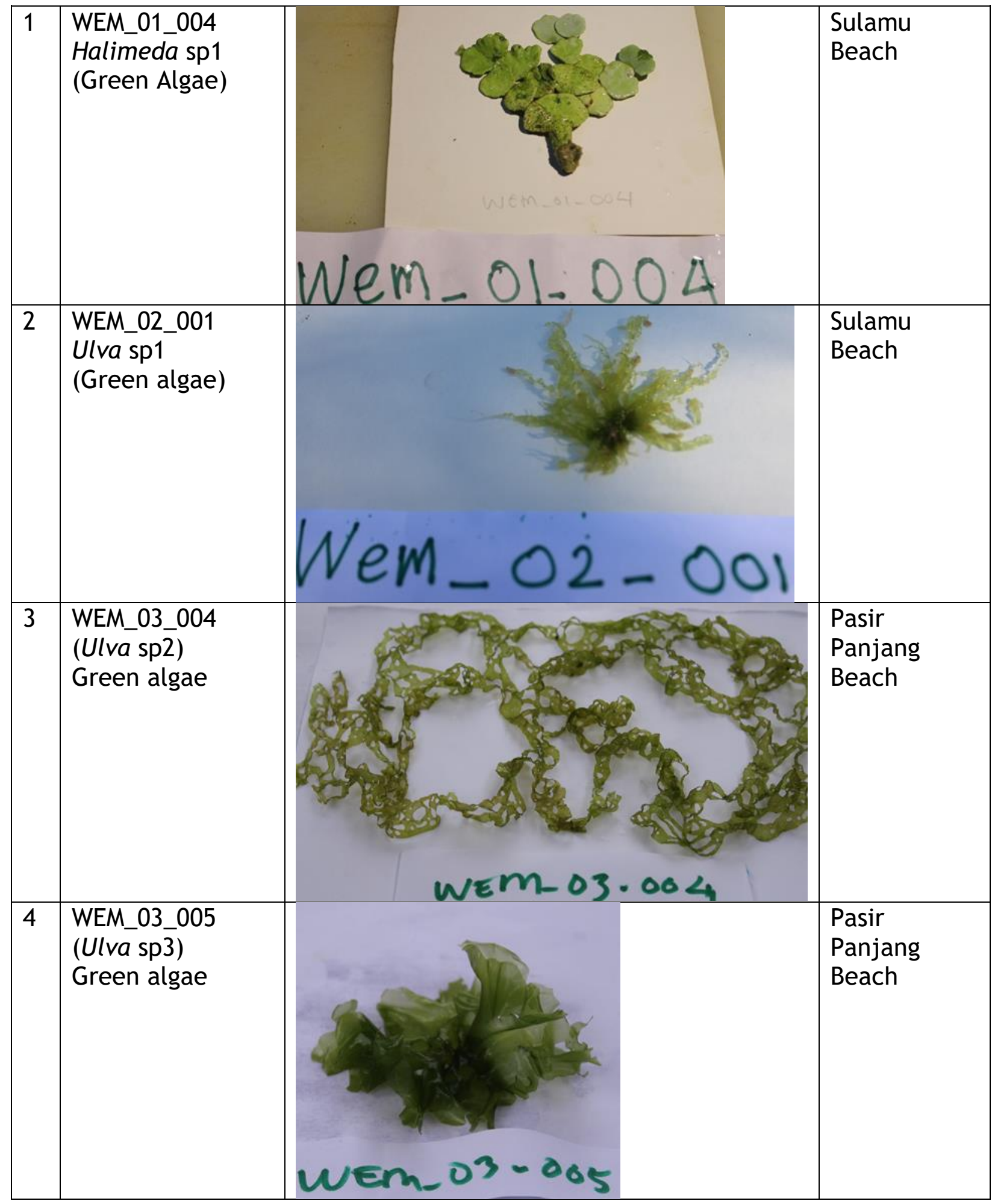




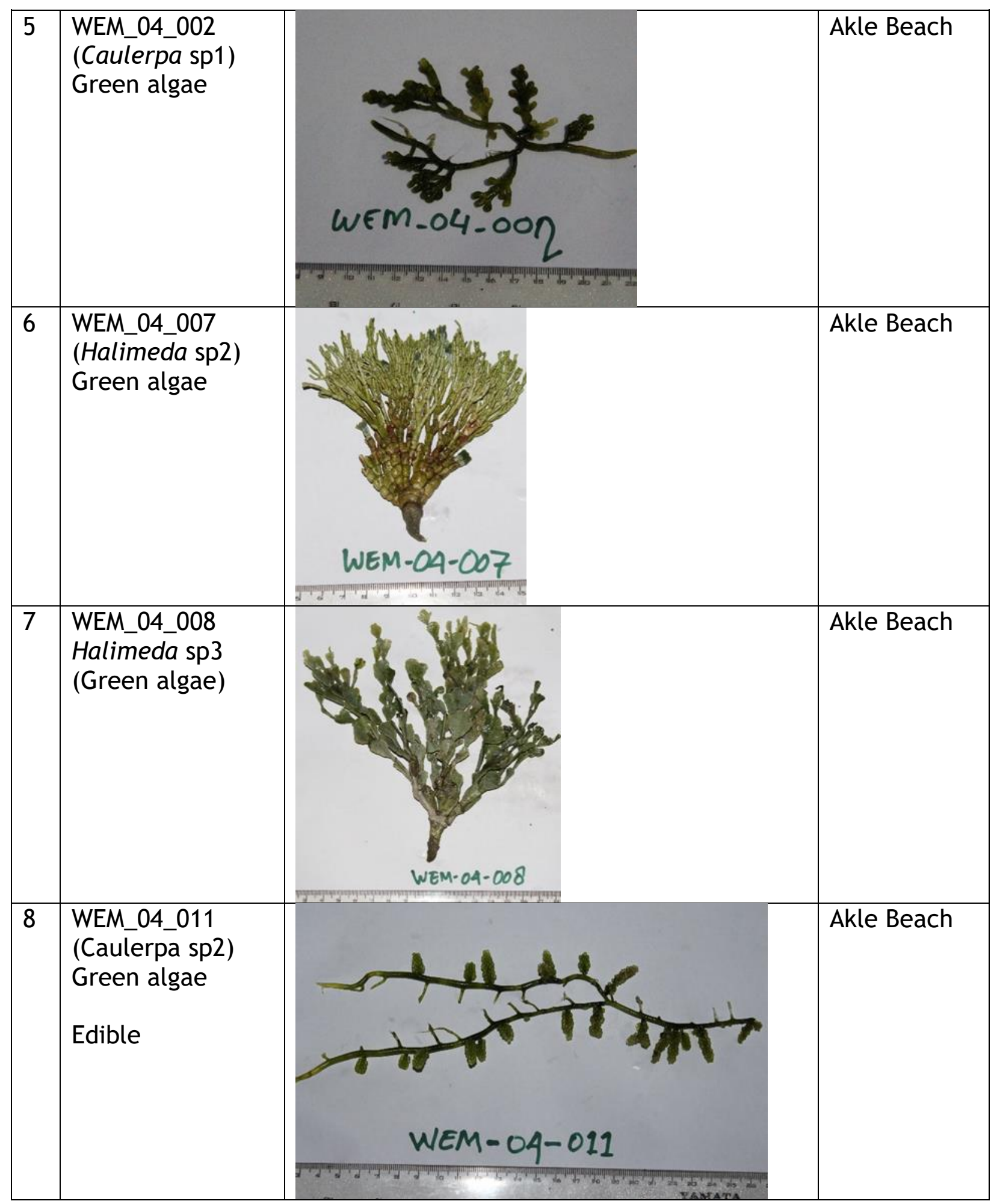




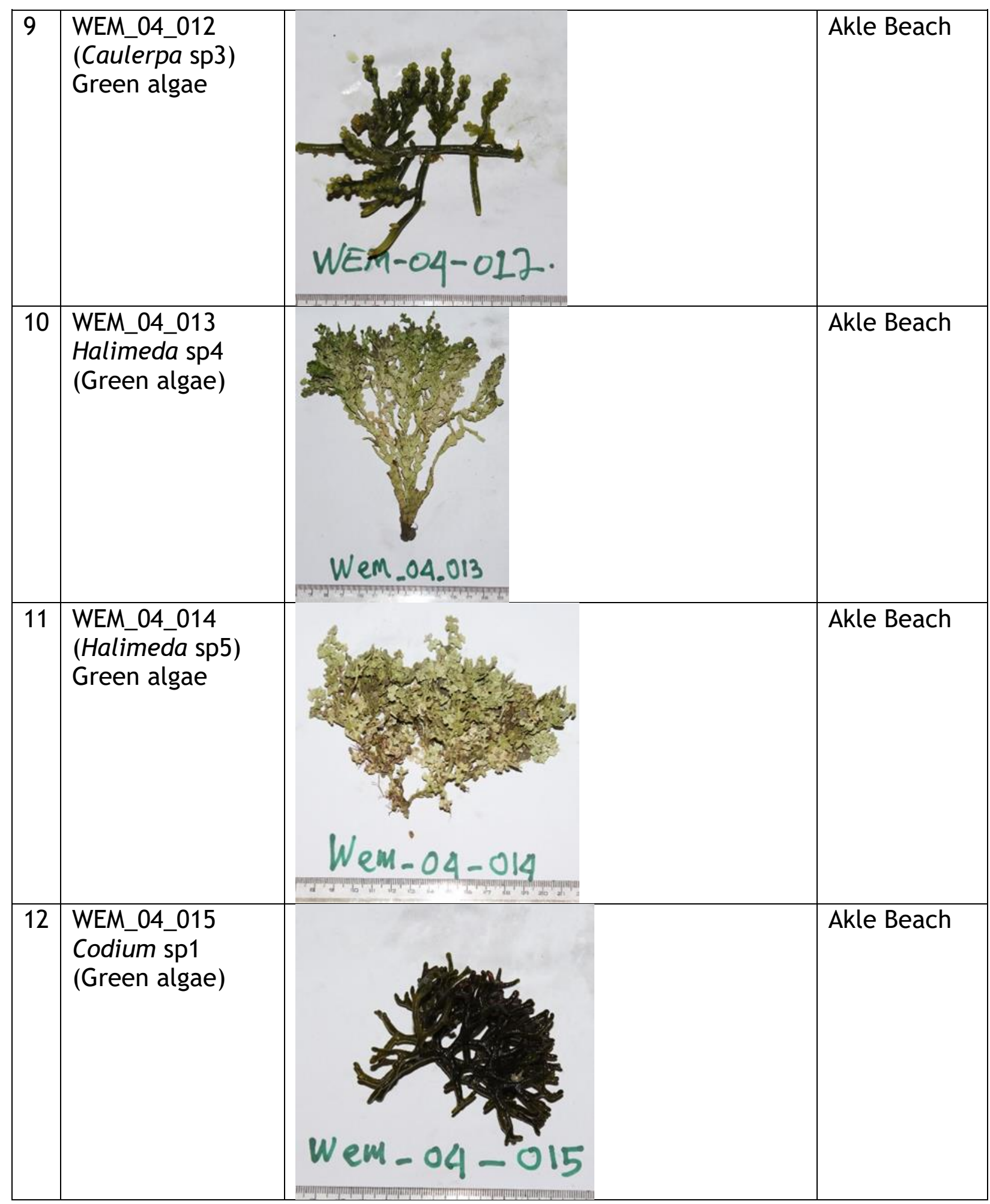




\begin{tabular}{|c|c|c|c|}
\hline 更 & $\begin{array}{l}\text { WEM_04_016 } \\
\text { Caulerpa sp4 } \\
\text { (Green algae) }\end{array}$ & Wem-04-016 & . \\
\hline . & $\begin{array}{l}\text { WEM_04_020 } \\
\text { Halimeda sp5 } \\
\text { (Green algae) }\end{array}$ & wem-04-020 & Akle Beach \\
\hline 15 & $\begin{array}{l}\text { WEM_05_003 } \\
\text { Codium sp2 } \\
\text { (Green algae) }\end{array}$ & $\begin{array}{l}\text { (1) } \\
\text { WEM-OS - }-003\end{array}$ & $\begin{array}{l}\text { Tablolong } \\
\text { Beach }\end{array}$ \\
\hline
\end{tabular}




\section{APPENDIX C: MACROALGAE EXTRACTS AFTER FREZE-DRY AND READY TO BE SENT TO VUW}

Sulamu Beach

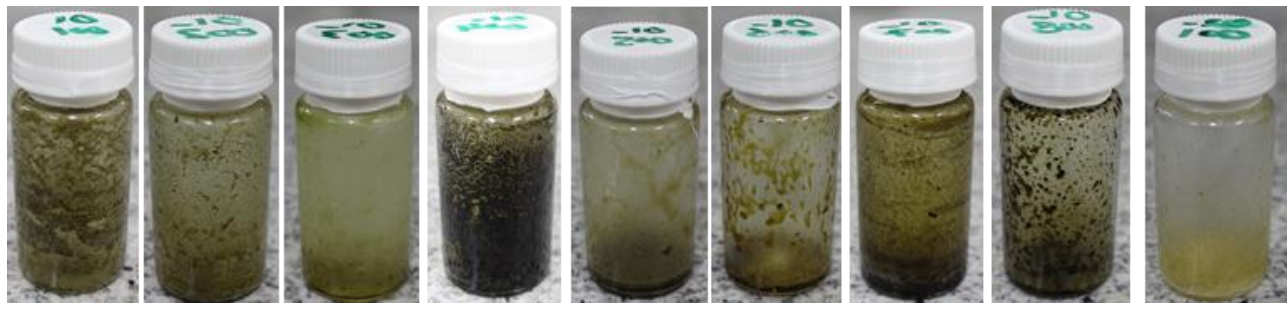

Pasir Panjang Beach
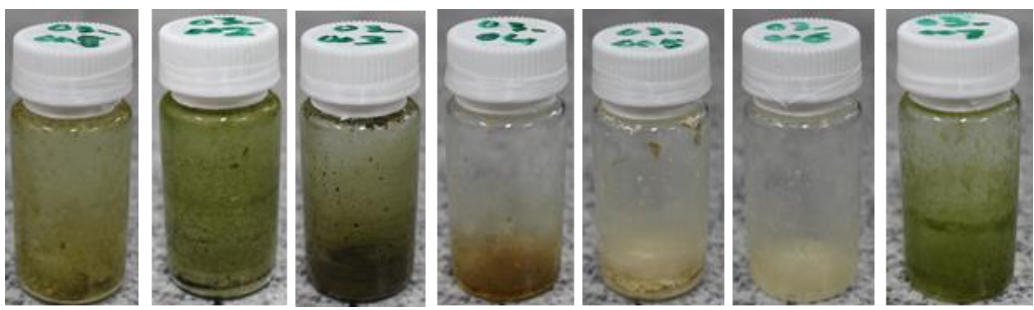

Akle Beach
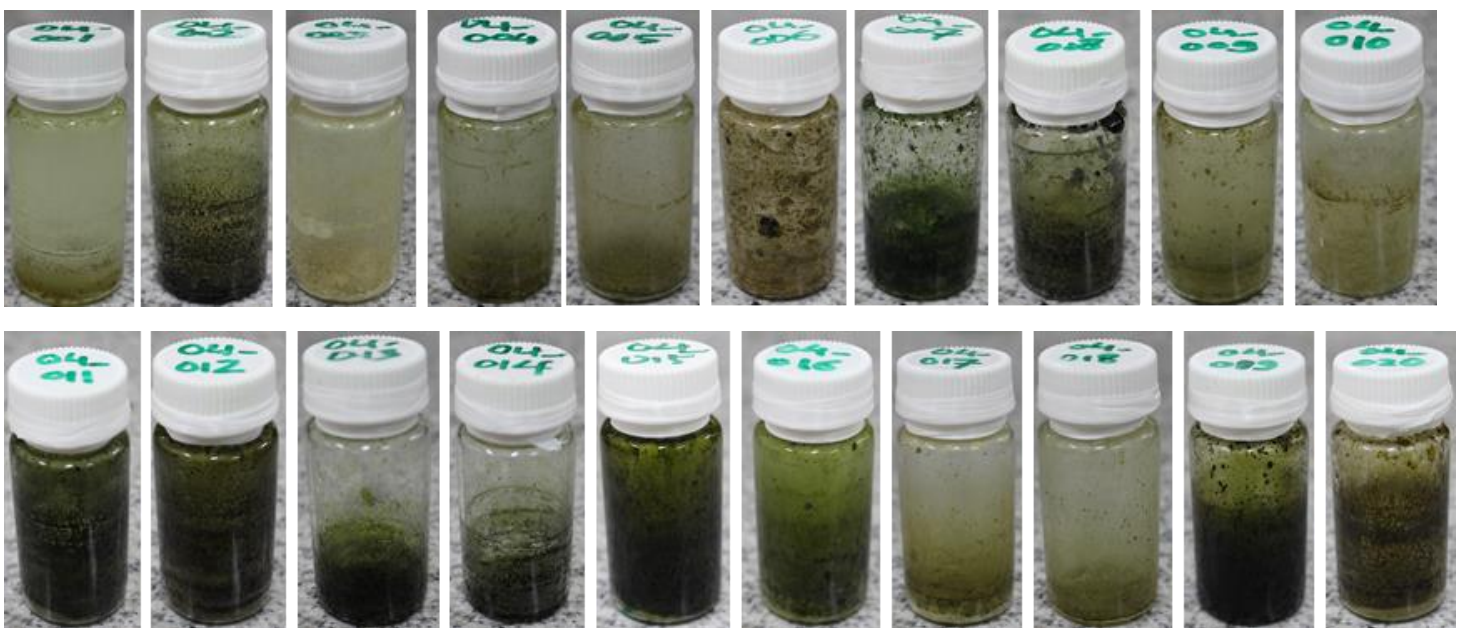

Tablolong Beach
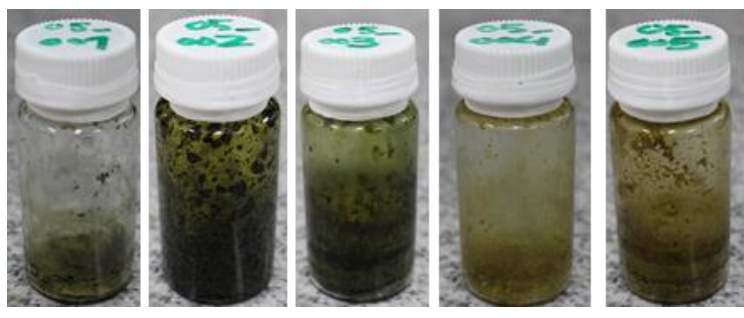


\section{APPENDIX D: 6-deoxy-6- aminoglycoglyrecolipid SPECTRA}

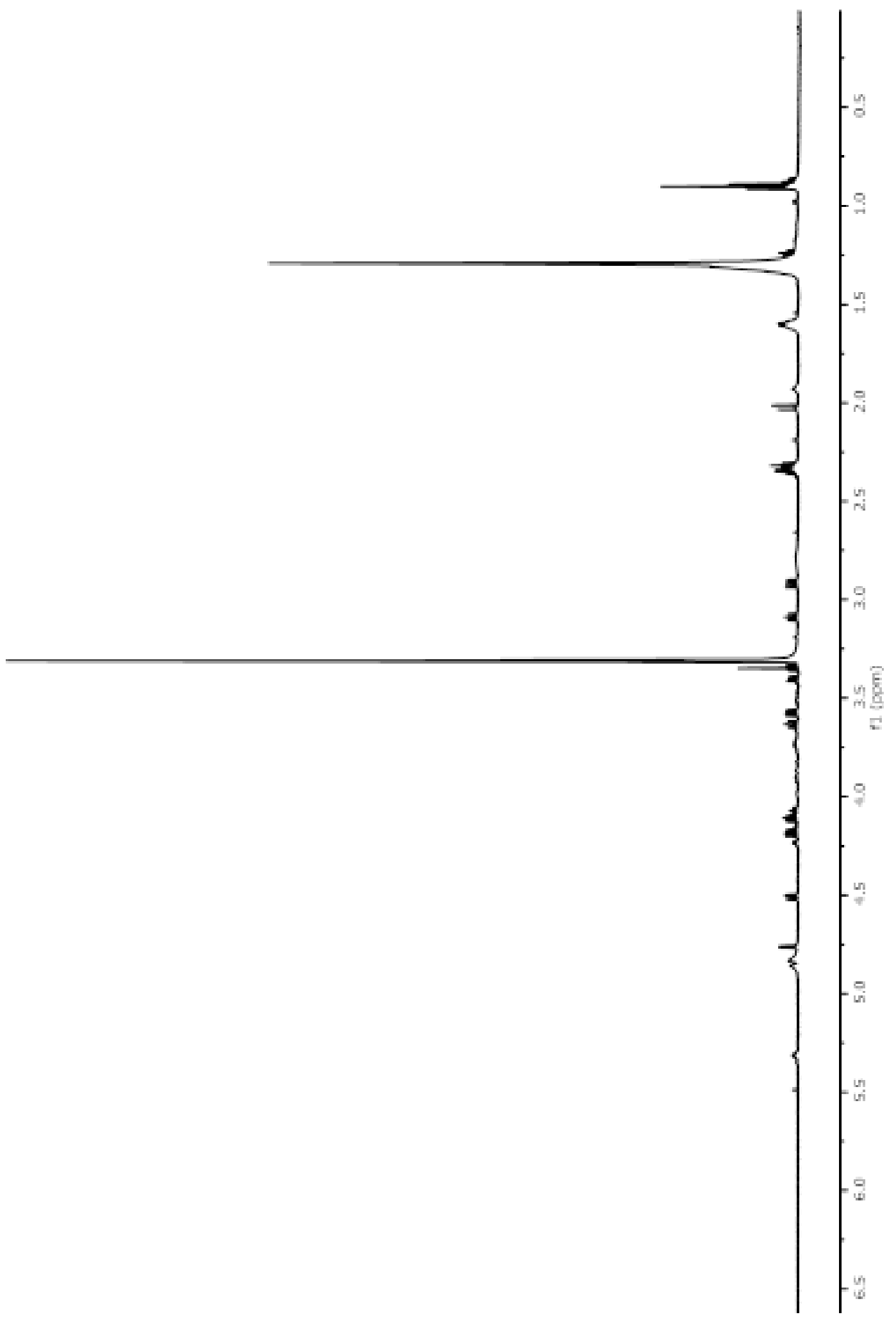

${ }^{1} \mathrm{H}$ NMR spectrum of 6-deoxy-6-aminoglycoglyrecolipid (60) $\left(600 \mathrm{MHz}, \mathrm{CD}_{3} \mathrm{OD}\right)$ 


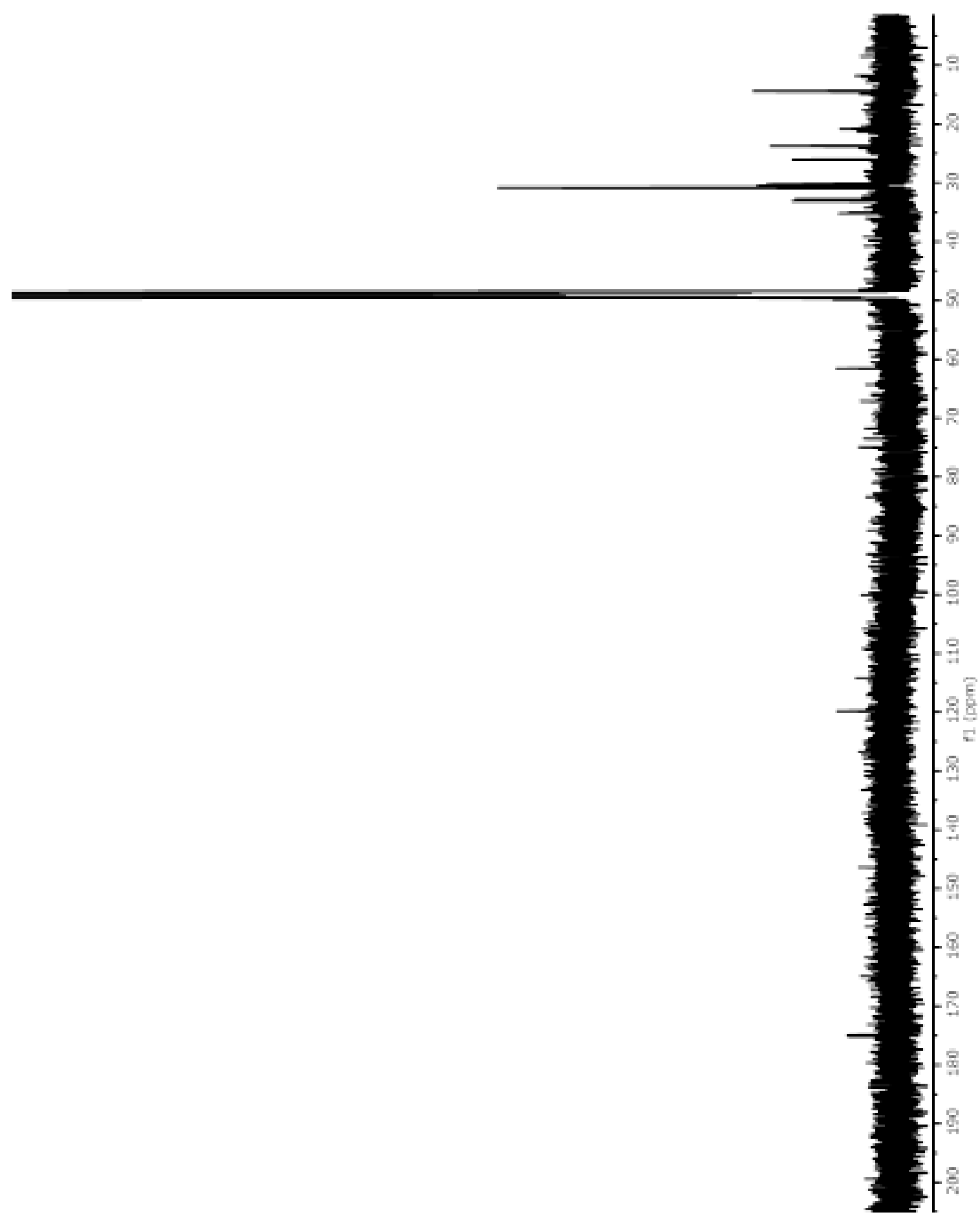

${ }^{13} \mathrm{C}$ NMR spectrum of 6-deoxy-6-aminoglycoglyrecolipid $(60)\left(150 \mathrm{MHz}, \mathrm{CD}_{3} \mathrm{OD}\right)$ 


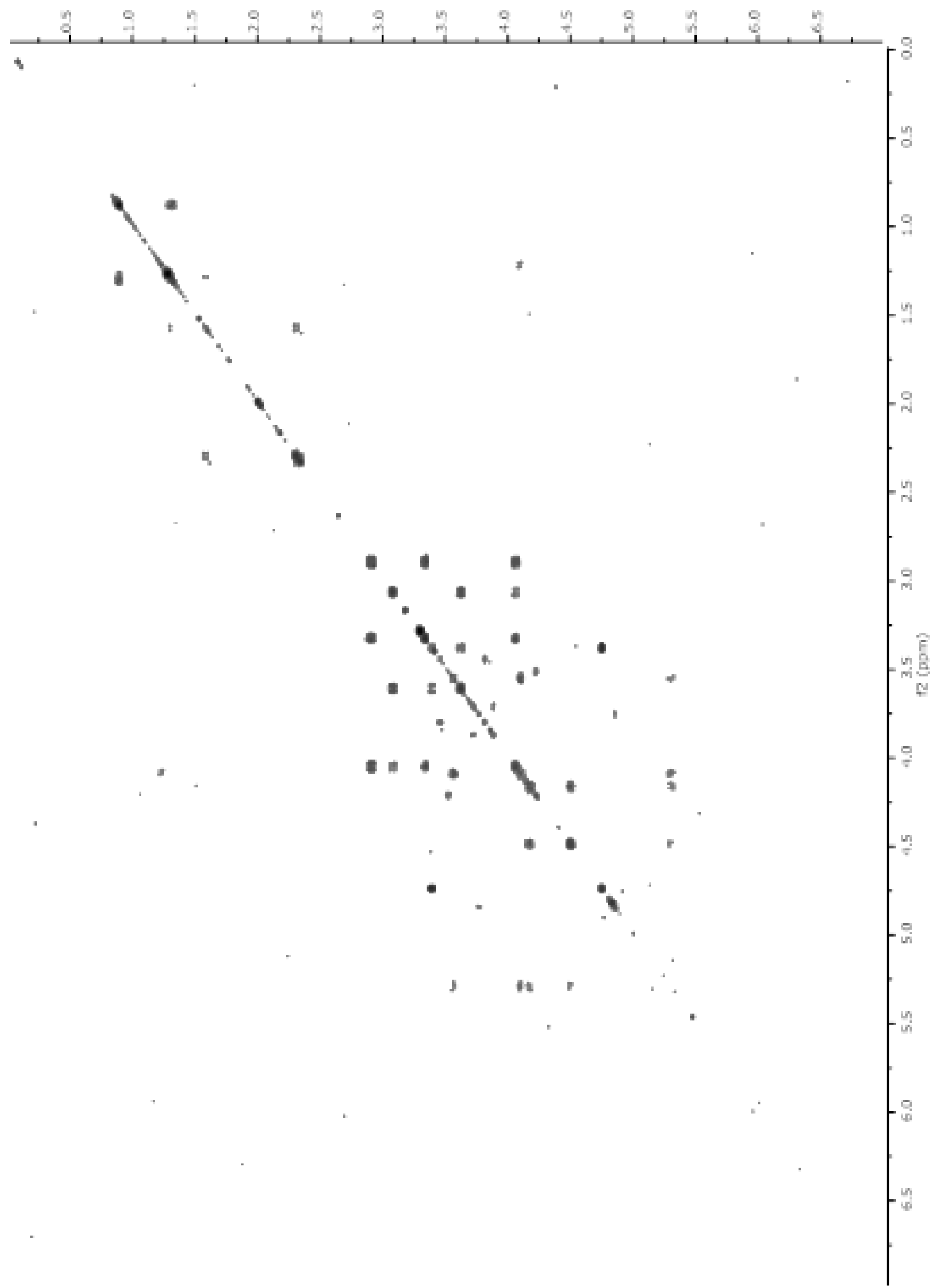

COSY spectrum of 6-deoxy-6-aminoglycoglyrecolipid (60) (600 MHz, CD 30 D) 
(used) ty

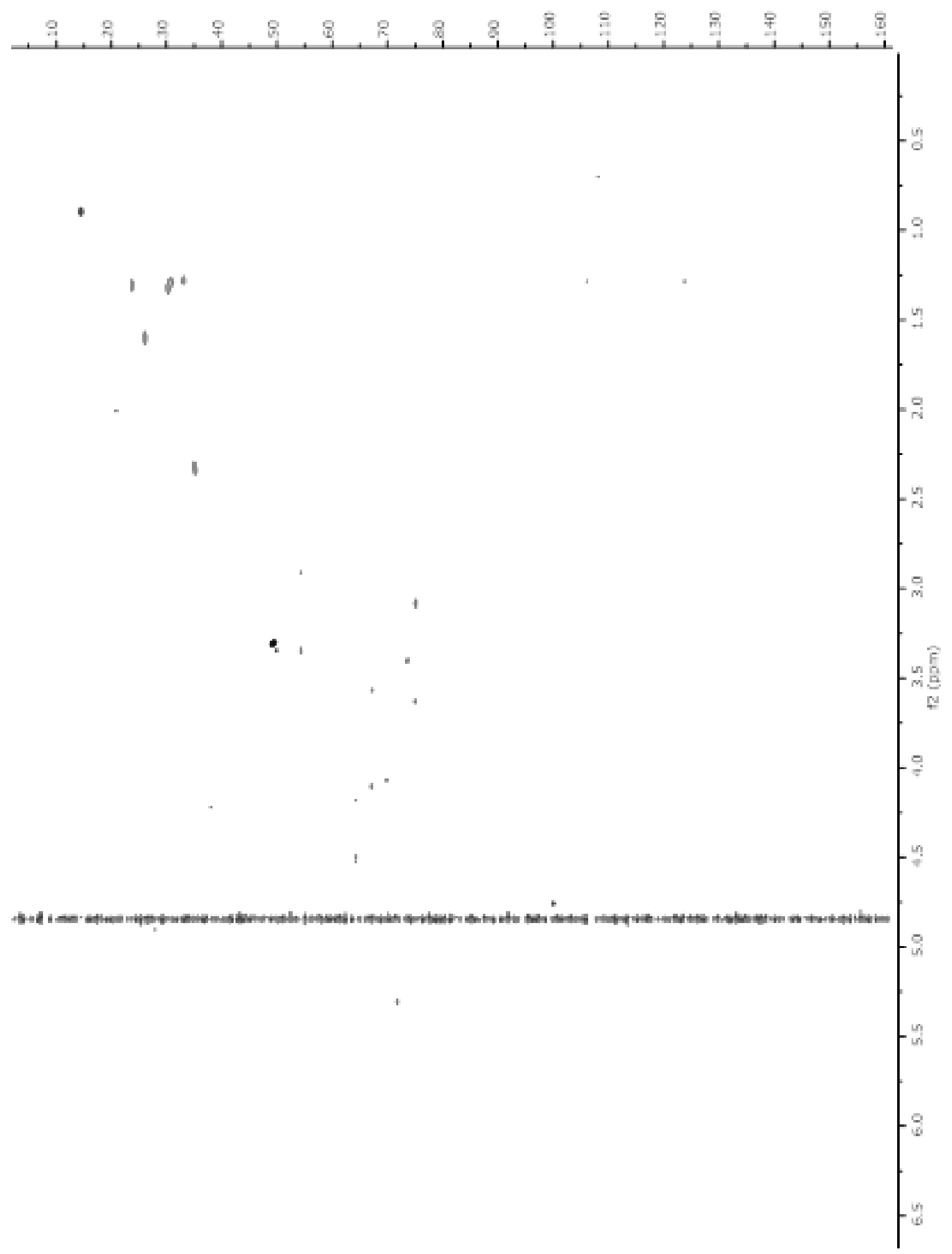

HSQC spectrum of 6-deoxy-6-aminoglycoglyrecolipid (60) $\left(600 \mathrm{MHz}, \mathrm{CD}_{3} \mathrm{OD}\right)$ 
(udd) If

이 ․․
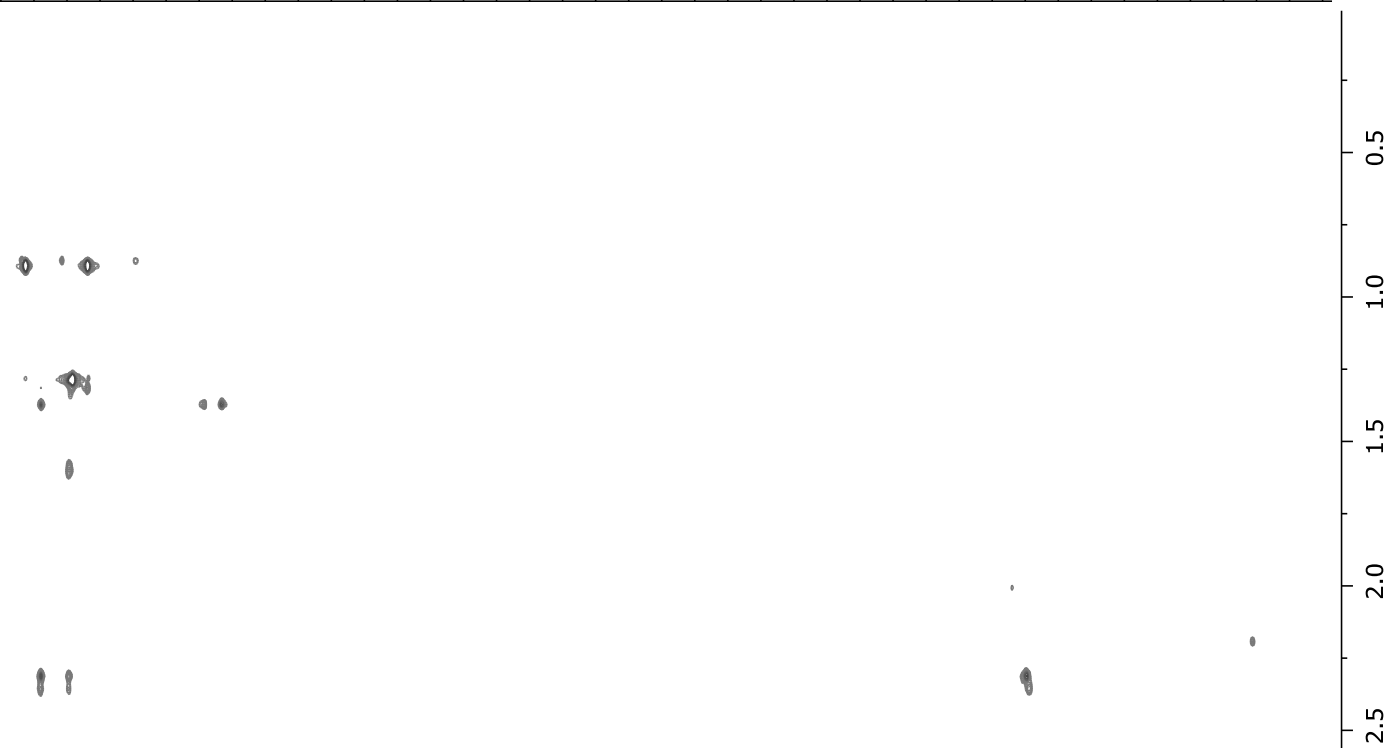

11

$\mathrm{HMBC}$ spectrum of 6-deoxy-6-aminoglycoglyrecolipid (60) $\left(600 \mathrm{MHz}, \mathrm{CD}_{3} \mathrm{OD}\right)$ 